\title{
GOSPODARSKE PRILIKE ZMAJEVIĆEVA GLAGOLJAŠKOG SJEMENIŠTA U ZADRU ZA VRIJEME REKTORA KANONIKA JOSIPA CALVIJA (1782. - 1810.)
}

\author{
Zdenko DUNDOVIĆ \\ Zadarska nadbiskupija \\ Zadar, Hrvatska
}

\author{
UDK: 272:37.07(497.5Zadar)“1782/1810“ \\ DOI: https://doi.org/10.21857/moxpjhgr8m \\ Izvorni znanstveni rad \\ Prihvaćeno: 5. listopada 2017.
}

U radu se na temelju računskih knjiga glagoljaškog sjemeništa u Zadru za vrijeme rektora kanonika Josipa Calvija (1782. - 1810.) razmatraju gospodarske prilike odgojno-obrazovne ustanove za hrvatsko svećenstvo Zadarske nadbiskupije koju je ustanovio zadarski nadbiskup Vicko Zmajević (1713. 1745.). Relevantni podatci o prihodima i rashodima Zmajevićeva glagoljaškog sjemeništa koncem 18. i početkom 19. stoljeća uspoređuju se $s$ dosadašnjim objavljenim rezultatima istraživanja gospodarskih prilika u Dalmaciji i Zadru u razmatranom razdoblju, a pomažu boljem razumijevanju ekonomske svakodnevice gradskog stanovništva. Analiza i sinteza obrađenog arhivskog gradiva pomaže rasvjetljavanju gospodarskih (ne)prilika glagoljaškog sjemeništa u Zadru prvenstveno s obzirom na učestale promjene državne vlasti u Dalmaciji koncem 18. i početkom 19. stoljeća, društveno-političke mijene, promjene vrijednosti monete u Dalmaciji i složenih pravnih odnosa između države i Crkve o pitanju nadarbina, zemljoposjedništva i upravljanja prihodima u razmatranom razdoblju.

Ključne riječi: glagoljaško sjemenište u Zadru, kanonik Josip Calvi, 18. i 19. stoljeće, gospodarstvo.

\section{UVOD}

Nadbiskupijsko sjemenište Zmajević u Zadru je odgojno-obrazovna institucija nastala na idejnom temelju zadarskog nadbiskupa Vicka Zmajevića (1713. - 1745.) u svrhu kvalitetnijeg odgoja hrvatskog svećenstva tijekom 18. stoljeća. Zmajevićevu ideju potvrdio je bulom papa Benedikt XIII. (1724. 1730.), a izgradnju sjemenišne zgrade u Zadru podržale su i odobrile tadašnje mletačke vlasti u Dalmaciji. Nadbiskup Zmajević umro je prije početka djelovanja hrvatskog glagoljaškog sjemeništa u Zadru. Dana 1. svibnja 1748. godine to je sjemenište svečano otvorio njegov nasljednik, zadarski nadbiskup Mate Karaman (1745. - 1771.).

Odmah po dolasku u Zadar Zmajević je uočio nisku razinu duhovne i kulture naobrazbe hrvatskog svećenstva koji je činio većinu pastoralnih djelatnika na području Zadarske nadbiskupije. Pronicljiva duha i iznimnih intelektualnih sposobnosti, prionuo je ostvarenju ideje o sjemeništu za hrvatske svećenike glagoljaše u samom srcu grada Zadra tik do njegove Prvostolnice, sv. Stošije. 
Godine 1998. zadarsko sjemenište Zmajević proslavilo je 250. godišnjicu postojanja. Tom prigodom održan je u rujnu 1999. godine u Zadru znanstveni skup o sjemeništu Zmajević, ali zbornik radova s toga skupa do danas nije ugledao svjetlo dana. Stoga se u radu, na temelju arhivskog gradiva Arhiva Zadarske nadbiskupije, želi prikazati onaj segment njegova djelovanja koji se odnosi na ekonomske prilike u kojima se nalazilo zadarsko sjemenište za administracije njegova rektora, zadarskog kanonika Josipa Calvija od 1782. do 1810. godine, i rasvijetliti dio svakodnevice glagoljaškog sjemeništa u Zadru koncem 18. i početkom 19. stoljeća.

\section{ADMINISTRACIJA GLAGOLJAŠKOG SJEMENIŠTA OD 1782. DO 1810. GODINE ZADARSKOG KANONIKA JOSIPA CALVIJA}

Zadarski kanonik Josip Calvi pok. Jakova rođen je u Zadru 1731. godine. Bio je potomak građanske obitelji podrijetlom iz Bergama. Imenovan je zadarskim arhiprezbiterom 26. veljače 1799. godine. Godine 1804. primljen je zajedno s bratom Dominikom u ninsko plemstvo. ${ }^{1}$ Umro je 31 . listopada 1816 . godine i pokopan je u obiteljskoj grobnici u crkvi sv. Frane u Zadru. ${ }^{2}$

S obzirom na to da je arhivsko gradivo nadbiskupskog sjemeništa Zmajević za 18. stoljeće netragom nestalo iz Arhiva Zadarske nadbiskupije, veliku vrijednost za proučavanje djelovanja te ustanove imaju sačuvani blagajnički dnevnici kanonika Josipa Calvija za vrijeme njegova upravljanja glagoljaškim sjemeništem u Zadru. Riječ je o tri knjige prihoda i rashoda glagoljaškog sjemeništa pod naslovom Amministrazione del Rettore Calvi per il Seminario Illirico di Zara. ${ }^{3}$ Prva knjiga obuhvaća razdoblje od Calvijeva imenovanja rektorom 14. ožujka 1782. godine do 14 . rujna 1790 . godine; druga knjiga obuhvaća razdoblje od 15. rujna 1790 . godine do 29 . kolovoza 1804 . godine, a treća knjiga obuhvaća razdoblje od 1. rujna 1804. godine do 28. prosinca 1810. godine. ${ }^{4}$ Paginacija stranica izvršena je na način da su verso i recto listovi knjige označeni identičnim brojem. Tako prva knjiga ima 95 , druga 183, a treća 85 paginiranih stranica. Prihodi glagoljaškog sjemeništa za razmatrano razdoblje upisivani su na verso

1 Usp. Miroslav Granić, Popis plemića grada Nina iz 1817. godine, Zbornik Odsjeka za povijesne znanosti Zavoda za povijesne i društvene znanosti HAZU, br. 32, Zagreb, 2014., 211.

2 Usp. Josip CELIĆ, Svjetovno svećenstvo i redovništvo u Zadru po službenom iskazu iz 1811. godine, Radovi Zavoda za povijesne znanosti HAZU u Zadru, sv. 57, Zadar, 2015., 222 - 223.

3 Arhiv Zadarske nadbiskupije (dalje: HR-AZDN), fond 6, Nadbiskupsko sjemenište Zmajević/ Nadbiskupska gimnazija u Zadru, Spisi, Računi i dnevnici blagajne, 18. i 19. st.

4 Kod citiranja se rabe skraćenice Liber I. za prvu knjigu koju obuhvaća razdoblje 1782. - 1790., Liber II. za drugu (1790. - 1804.) i Liber III. za treću knjigu (1804. - 1810.). 
listu knjiga izrazom Cassa deve Avere, a rashodi na recto listu knjiga izrazom Cassa deve Dare. Uz redovite prihode i rashode glagoljaškog sjemeništa upisivao je rektor Calvi i poneke crtice o društveno-političkim, crkvenim i monetarnim mijenama u Zadru koncem 18. i početkom 19. stoljeća pa se računske knjige iz razmatranog razdoblja mogu promatrati i kao svojevrsni dnevnik zapažanja u vrijeme turbulentnih političko-geografskih promjena, tj. izmjena mletačke, prve austrijske i francuske uprave u Dalmaciji u svega 15-ak godina.

Analizom dostupnih podataka $u$ administrativnim knjigama rektora Calvija donosi se rekonstrukcija ekonomskog života glagoljaškog sjemeništa koncem 18. i početkom 19. stoljeća, ali i poneki skromni prinos poznavanju života grada Zadra i njegove okolice u crkvenom, gospodarskom i društveno-političkom smislu u razmatranom razdoblju. U zapisima troškova stoji da je Calvi na početku svoje službe osobno kupio administrativne knjige, a uz to su rektor i ekonom vodili zasebne dnevne knjige (giornali), što jasno ukazuje da su morale postojati takve knjige i drugih rektora prije Calvija, no njih se do danas nije pronašlo. ${ }^{5}$ Jednako se spominje i knjiga inventara prigodom primopredaje rektorske službe (Libro inventario di mio pugno). ${ }^{6}$

\section{NADARBINA SAMOSTANA SV. KRŠEVANA I SV. PETRA NA OSORU U KORIST GLAGOLJAŠKOG SJEMENIŠTA U ZADRU}

U listopadu 1725. godine obratio se nadbiskup Zmajević preko generalnog providura Nikole Erizza mletačkoj vladi da mu dopusti preko papinskog nuncija u Veneciji uputiti zamolbu Svetoj Stolici za podizanje un seminario illirico u Zadru, ${ }^{7}$ što je mletački Senat odobrio 8. studenoga 1725. godine. ${ }^{8}$

5 Per il presente Libro dell'Amministrazione ed altro consimile Quaderno e due altri di minor mole detti Giornali uno per me e l'Altro p(er) l'Economo 17:10 (17 lira i 10 soldi). Liber I, 1.

6 Liber I, 1.

7 Ante Marija Strgačıć, Hrvatski jezik i glagoljica u crkvenim ustanovama grada Zadra, Zadar Zbornik, ur. Jakša Ravlić, Zadar, 1964., 414.

8 1725. 8. Nouembre in Pregadi. Al Proueditor General in Dalmazia, et Albania. Caeteris Omissis. Distinta in primo luogo è l' informazione che uenite di rilleuarci sopra il memorial di Monsignor Arciuescouo Smaieuich (per) la institituzione di un Seminario Illyrico, suo fabrica, qualità e numero delli Alunni e Maestri, et Capitoli, con il metodo pure ch' esponete tenersi nel Seminario Latino. Venendo però di secondarsi dal Senato opera cosi degna, che tende al maggior Culto del Signor Dio, nell'oggetto importante d'instruirsi persone Religiose, che deuono poi seruire (per) Curati delle Anime, concorre a permettere con la errezione del Seminario stesso la faccoltà a quell zelante Pastore di ricorrere a Roma (per) impetrare qualche beneffizio (per) applicarne la rendita al mantenimento del medesimo. HRAZDN-18, Prvostolni kaptol u Zadru, Razni spisi, svež. 69, fol. 76r-v. Kratku povijest Zmajevićeva sjemeništa vidi kod: Carlo Federico BıAnCHI, Zara Cristiana I, Zadar, 1877., 267 - 271. 
Loše materijalno stanje i neukost seoskog glagoljaškog svećenstva temeljni su razlozi Zmajevićeva zahtjeva za podizanje glagoljaškog sjemeništa u Zadru. ${ }^{9}$ $\mathrm{Na}$ temelju odobrenja mletačke vlade per l'erezione del Seminario Illirico in Zara si licenzia con la clausola: a tenore dell Decreto 8 Novembre 1725, che ha permesso tal erezione, et il riscorso a Roma $^{10}$ papa Benedikt XIII. izdao je 30. prosinca 1729. godine bulu ${ }^{11}$ o pripojenju nadarbina benediktinskih opatija sv. Krševana u Zadru i sv. Petra u Osoru za izgradnju i održavanje glagoljaškog sjemeništa. ${ }^{12}$ Za izvršitelja papinske bule imenovan je ninski biskup Ivan Andrija Balbi (1692. - 1771.), ${ }^{13}$ a na dan otvorenja glagoljaškog sjemeništa zastupnikom pripojenih nadarbina imenovan je don Benedikt Spinelli. ${ }^{14}$ Zbog pripojenja nadarbina samostana sv. Krševana u Zadru i sv. Petra u Osoru izbio je sudski spor između samostana sv. Krševana i glagoljaškog sjemeništa u Zadru koji je trajao od 1748. do 1756. godine. Naime, bulom pape Benedikta XIII. nadarbine samostana sv. Krševana i sv. Petra u Osoru s naslova komende ${ }^{15}$ pridodane su u korist glagoljaškog sjemeništa u Zadru kao jednostavna nadarbina (beneficia simplex). ${ }^{16}$ Posljednjeg komendatora nadarbine sv. Krševana Franju Tetu imenovao je papa Inocent XI. 1685. godine, a komendator nadarbine sv. Petra bio je opat Capitani. ${ }^{17}$ Obveza komendatora bila je podavati $1 / 3$, a kasnije, kako je razvidno iz papinskih bula, $1 / 4$ prihoda nadarbine crkvi i samostanu sv. Krševana. ${ }^{18}$ Razvidno je iz dokumenata da komendator Teta nije redovito

9 O uzrocima takvoga stanja vidi više kod: Ante Marija STRGAČıć, O uzgoju i naucima dalmatinskoga glagoljskog klera u prošlosti, Zadarska revija, br. V, Zadar, 1956., 179 - 184.

10 Archivio di Stato di Venezia, (dalje: ASV), Consultori in Jure, fil. 280-82, fol. 4r.

11 Prijepis bule pape Benedikta XIII. donosi se u prilogu radu (Prilog 1). Jedan prijepis bule sačuvan je u rukopisu Ivana Gurata Notizie circa la Chiesa Metropolitana di Zara e Seminario Illirico u Znanstvenoj knjižnici u Zadru pod signaturom 16523, Ms. 452, fol. 20r-29r.

12 O benediktinskim opatijama sv. Krševana u Zadru i sv. Petra u Osoru vidi više kod: Ivan OstojIć, Benediktinci u Hrvatskoj, sv. II, Split, 1964., 39 - 55; 149 - 155.

13 Državni arhiv u Zadru (dalje: HR-DAZD), fond 336, Benediktinski samostan Sv. Krševana, Spor s Ilirskim/glagoljaškim sjemeništem u vezi s prihodima i podjelom nadarbine, 1729./1766., kut. 4, svež. 1.4.4., fol. 55r.

14 HR-DAZD-336, Benediktinski samostan sv. Krševana, kut. 4, svež. 1.4.4., fol. 55v.

15 O sustavu komendi vidi više kod: Jadranka Neralić, Pensionem annuam ducentarum et quinquaginta librarum monete in illis partibus currentis, annis singulis quoad uixerit per abbatem dicti monasterii integre et efficaciter persoluendarum: obveze opata dalmatinskih benediktinskih opatija prema Apostolskoj komori u 15. stoljeću, Vjesnik Arheološkog muzeja u Zagrebu, 45 (1) 2013., $467-482$.

16 O jednostavnim nadarbinama vidi više kod: Jadranka Neralić, Put do crkvene nadarbine, Split, 2007., $106-107$.

17 HR-DAZD-336, Benediktinski samostan sv. Krševana, kut. 4, svež. 1.5.1., fol. 215v.

18 HR-DAZD-336, Benediktinski samostan sv. Krševana, kut. 4, svež. 1.5.1., fol. 39r. 
ispunjavao svoje obveze prema samostanu sv. Krševana, a nakon njegove smrti 1748. godine sjemenište je, pozivajući se na konstitucije ustanove glagoljaškog sjemeništa i bulu pape Benedikta XIII., odbijalo podavati samostanu bilo kakav prihod. ${ }^{19}$ Uprava glagoljaškog sjemeništa pravdala je takav stav teškim materijalnim stanjem i opterećenjem koje bi ta obveza sa sobom nosila. ${ }^{20}$ Nakon dugotrajnog sudskog procesa na sudištima u Zadru i Veneciji konačno je mletačko Vijeće Četrdesetorice presudilo 15. ožujka 1756. godine u korist samostana sv. Krševana zbog čega u administrativnim knjigama rektora Calvija često pratimo upise rashoda za potrebe obnove crkve sv. Krševana. ${ }^{21}$

U razmatranom razdoblju prihodi tih nadarbina iznosili su oko 200 dukata, a troškovi žetve, berbe, plaća za upravitelje sjemenišnih posjeda te prijevoza prikupljenih prinosa iznosili su oko 30 dukata. ${ }^{22} \mathrm{Za}$ te nadarbine u razmatranom razdoblju redovito se državi plaćao porez (Redecima) u visini od 43 dukata i 21 groša za nadarbinu sv. Krševana te 17 dukata i 15 groša za nadarbinu sv. Petra u Osoru. ${ }^{23}$ Nakon podmirenja svih obveza sjemeništu je ostalo 115 dukata, odnosno 2530 mletačkih lira. ${ }^{24}$

ZahvaljujućiizvješćuzadarskogarhiđakonaIvanaCarsaneposlanog mletačkom Senatu u Veneciji sa sigurnošću možemo locirati zemljišta i gospodarska dobra samostana sv. Krševana pod ingerencijom zadarskog sjemeništa tijekom 18. stoljeća kao i njihovu prostornu površinu. Prema odredbi mletačkog Senata od 28. siječnja 1768. godine, zadarski arhiđakon Ivan Carsana dostavio je 1. travnja 1770. godine popis crkvenih nadarbina na području Zadarske nadbiskupije koji su pohranjeni u Državnom arhivu u Veneciji pod naslovom Zara Campatico. ${ }^{25}$ Tablično se prikazuje popis, položaj i veličina nadarbine samostana sv. Krševana u Zadru u korist glagoljaškog sjemeništa 1770. godine izražena u padovanskim kampima ${ }^{26}$ što ih potpisuje tadašnji rektor don Ivan Lisičić (Tablica 1).

19 HR-DAZD-336, Benediktinski samostan sv. Krševana, kut. 4, svež. 1.5.1., fol. 216v-217r.

20 HR-DAZD-336, Benediktinski samostan sv. Krševana, kut. 4, svež. 1.5.1., fol. 199r-v.

21 HR-DAZD-336, Benediktinski samostan sv. Krševana, kut. 4, svež. 1.5.5., neoznačeni foliji.

22 HR-AZDN-16/1, Zadarska nadbiskupija/Metropolija, Registrum litterarum, Dopisivanje zadarskih nadbiskupa: Carsana, 1774. - 1790., knj. 1, 29. travnja 1785. godine.

23 Liber II, 155.

24 HR-AZDN-16/1, Zadarska nadbiskupija/Metropolija, Registrum litterarum, Dopisivanje zadarskih nadbiskupa: Carsana, 1790. - 1800., knj. 1., izvješće zadarskom knezu Jerolimu Bragadinu od 5. srpnja 1792. godine.

25 ASV, Sopraintendenti alle decime del Clero, Zara Campatico, b. 284.

26 Padovanski kamp iznosio je 3,656 m², dijelio se na četiri kvarte, a kvarta je iznosila 210 tavola. Usp. Mirela Slukan-Altić, Povijest mletačkoga katastra Dalmacije, Arbivski vjesnik, (43) 2000., 182. 
TABlica 1. Popis nadarbina samostana sv. Krševana u korist glagoljaškog sjemeništa 1770. godine

\begin{tabular}{|l|l|l|l|l|l|}
\hline Mjesto & Oranice & Vinogradi & Maslinici & Zasijano & Neupotrebljivo \\
\hline Brbinj & $9 \mathrm{kampa}$ & $36 \mathrm{kampa}$ & $21 \mathrm{kamp}$ & $15 \mathrm{kampa}$ & $324 \mathrm{kampa}$ \\
\hline Savar & $8 \mathrm{kampa}$ & $2 \mathrm{kampa}$ & $12 \mathrm{kampa}$ & - & $146 \mathrm{kampa}$ \\
\hline $\begin{array}{l}\text { Dračevac } \\
\text { Zadarski }\end{array}$ & $11 \mathrm{kampa}$ & $40 \mathrm{kampa}$ & $10 \mathrm{kampa}$ & - & $210 \mathrm{kampa}$ \\
\hline Neviđane & $40 \mathrm{kampa}$ & $30 \mathrm{kampa}$ & $23 \mathrm{kampa}$ & $12 \mathrm{kampa}$ & $340 \mathrm{kampa}$ \\
\hline Sali & $20 \mathrm{kampa}$ & $40 \mathrm{kampa}$ & $8 \mathrm{kampa}$ & - & - \\
\hline
\end{tabular}

Izvor: ASV, Sopraintendenti alle decime del Clero, Zara Campatico, b. 284.

Zemljišta u Brbinju bila su smještena uz samo naselje, a jedan dio i na kamenitom brdu (nel Monte Petroso). U Savru su zemljišta bila uglavnom neplodna i donosila su slab prihod. Na Dračevcu Zadarskom (Malpaga) zemljišta su bila smještena na brdu, u blizini samoga naselja, i ispod brda (u polju) prema seoskim bunarima Stubalj i Smokvica. U Neviđanima je većina terena bila ravničarske konfiguracije, a dio je bio smješten na okolnim brdima i brežuljcima. U Salima su zemljišta također bila neplodna, ali je sjemenište tamo posjedovalo velike pašnjake u Telašćici za uzgoj stoke sitnog zuba (ovce i koze). Sjeverno od zemljišta u Salima sjemenište je posjedovalo i pašnjake na lokalitetu Gračine, uzvisini u blizini Žmana. Uz navedeno u posjedu sjemeništa bila su i dva pašnjaka malih prihoda na otoku Maunu koji je u cijelosti spadao u vlasništvo sjemeništa. ${ }^{27}$

$\mathrm{U}$ dokumentu od 20. prosinca 1782. godine sklopio je Calvi u ime sjemeništa sa svećenikom Antom Budešom (Budessa) s Oliba ugovor o najmu pašnjaka na otoku Maunu, s godišnjom daćom od 1060 lira i s obvezom podavanja jednog velikog ovna u mjesecu svibnju (un Castra grande da Lana) i 15 malih sireva. ${ }^{28}$ Nakon smrti don Ante Budeše 1797. godine ${ }^{29}$ novi ugovor o najmu sklopljen je s njegovim nećakom Jurom. ${ }^{30}$ Redovito su se ugovori sklapali na 3 - 5 godina, a najam se plaćao u dvije godišnje rate o Uskrsu i Božiću. ${ }^{31}$ U slučaju troškova najmitelja za obnovu crkve na Maunu utrošeni iznos odbijao bi se od godišnje rate najma. ${ }^{32}$ Sjemenište je o svom trošku održavalo crkvu i sve potrebno za liturgijsko

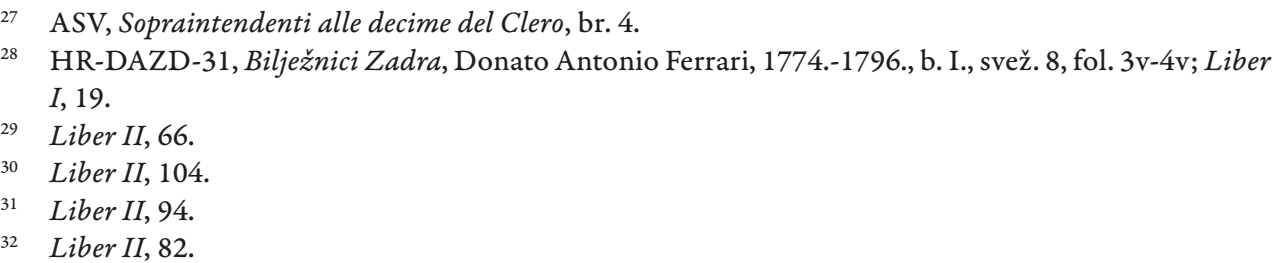


slavlje na tom otoku, ${ }^{33}$ od čega valja istaknuti obnovu oltarne pale 1794. godine koja je povjerena slikaru Serafinu Bigoniju. ${ }^{34}$ Posljednji ugovor za najam otoka Mauna sklopio je Calvi s Budešom 1805. godine za 1440 lira godišnje daće. ${ }^{35}$

Zemljišta i pašnjake u Neviđanima pod nadarbinom samostana sv. Krševana u najam je uzela obitelj Arvatini (Hrvatinić) ${ }^{36}$ za 2500 lira godišnje. ${ }^{37}$ Ugovor o posjedima u Neviđanima sklopili su rektor glagoljaškog sjemeništa don Ivan Lisičić i Julije Arvatini ${ }^{38}$ 17. travnja 1768. godine kod javnog bilježnika Antonija Ferrarija, a nakon Julijeve smrti rektor Calvi sklopio je novi ugovor s Julijevim bratom Antunom Arvatinijem 11. lipnja 1788. godine kod javnog bilježnika Domenica Castellija. ${ }^{39}$ Dana 20. travnja 1771. godine uzeo je Julije Arvatini u najam pašnjak Gračine u blizini Žmana za 120 lira godišnje..$^{40}$ Posljednji pripadnik obitelji Arvatini s kojim je Calvi sklopio ugovor o najmu bio je kapetan Josip Arvatini, ${ }^{41}$ a godišnja daća 1809. godine za ta zemljišta iznosila je 4240 dalmatinskih, odnosno 1767 mletačkih lira. ${ }^{42}$

$\mathrm{Na}$ Dugom otoku sjemenište je dalo u najam vinograde i maslinike u Salima ${ }^{43}$ i na lokalitetu Jezero u Žmanu Juri Rakaru, Donatu Rudinu, Ivanu i Juri Švorco (Sforzo) iz Sali 26. siječnja 1778. godine s godišnjom daćom od 1000 lira u dvije rate. ${ }^{44}$ Dana 13. prosinca 1783. godine ti su posjedi dani u najam don Anti Basioliju i Valentinu Petricioliju. ${ }^{45}$ Pašnjaci u Telašćici i sjemenišna sitna stoka

33 Liber II, 105.

34 Liber II, 46. O slikaru Serafinu Bigoniju vidi više kod: Bojan GojA, Novi prilozi o baroknom slikarstvu u Zadru, Radovi Instituta za povijest umjetnosti, br. 38, Zagreb, 2014., 138 - 139.

35 Liber III, 16.

36 O obitelji Arvatini vide više kod: Lovorka Čoralıć, Građanske obitelji Arvatini i Cavaletti prilog poznavanju društvene i kulturne povijesti Zadra u XVII. i XVIII. stoljeću, Zbornik Odsjeka za povijesne znanosti Zavoda za povijesne i društvene znanosti HAZU, br. 26, Zagreb, $2009 ., 87$ 141

37 Liber I, 61.

38 Julije Arvatini bio je sakupljač crkvene desetine na Dugom otoku. Liber I, 63.

39 Liber $I, 77$.

40 Liber $I, 5$.

41 Liber II, 157.

42 Liber III, 59.

43 U spisima zadarskog bilježnika Donata Antonija Ferrarija nalazi se dokument u kojem se približno određuje položaj sjemenišnih posjeda na tom području: ...Stiuagne Poglie, tener di Sale, dalla Loqua in Maistro, fondo Seminario Illirico. HR-DAZD-31, Bilježnici Zadra, Donato Antonio Ferrari, 1774.-1796., b. 3, svež. 3, protokol 17, neoznačen folij. Loqua označava umjetno napravljen sustav vodoopskrbe za zalijevanje polja i napajanje stoke. Usp. Urška STRAžıšAR, Skriveni tragovi: Voda kao kulturna baština u mjestu Sali i Parku prirode Telašćica, Etnološka istraživanja, br. 15, Zagreb, 2010., 76.

44 Liber $I, 5$.

45 Liber I, 27. 
dana je 12. lipnja 1775. godine u najam Ivanu i Mati Šešelji iz Zaglava i Jadri Žampjeri iz Žmana za 1500 lira godišnje daće na ime najma uz obvezu podavanja 6 jarića svakog prvog u mjesecu rujnu i za Božić te 40 libri sira i 4 puine, ${ }^{46}$ a kasnije je obveza porasla na 44 libre sira iznimne kakvoće za Veliku Gospu i Božić i dva najbolja jarića i 4 puine (skute, vrsta mliječnog proizvoda nalik siru) za Svi Svete, Uskrs i Duhove na ime regalie (darivanja). ${ }^{47}$ Zemlje u Dragovama površine 24 gonjaja dane su u najam ženskom samostanu sv. Katarine u Zadru za 17 lira godišnje daće. ${ }^{48}$ Novac od nadarbine opatije sv. Petra na Osoru išao je u ruke zadarskog nadbiskupa sve do smrti nadbiskupa Ivana Carsane, a radilo se o iznosu od 11424 dalmatinske lire godišnje, ${ }^{49}$ a nakon njegove smrti isplaćivao se rektoru Calviju u dvije godišnje rate. Najmitelji te nadarbine bili su kanonik Petar Bonicelli iz Velog Lošinja i kapetan Šime Budinić te njihovi udruženici. ${ }^{50}$

Neka sjemenišna zemljišta na području Bibinja i Dračevca Zadarskog dana su u kolonat: 1789. godine Matiji i Mihovilu Karliću iz Kukljice te Petru Lisici i Mati Šindiji iz Bibinja; ${ }^{51}$ 1791. godine Antoniju Reggiju iz Mantove nekultivirano, kamenito i šumovito zemljište od 3 gonjaja $^{52}$ te 1795 . godine jedna livada na lokalitetu Smokvica na Dračevcu Zadarskom na 10 godina i šumarak na brijegu koji iz Bibinja vodi prema Dračevcu; ${ }^{53}$ 1793. godine Šimi Mičiću pok. Ivana dva komada zemlje na Dračevcu Zadarskom; $;^{54} 1803$. godine Stipanu Miščeviću teren od 7 dana oranja na lokalitetu Police u Dračevcu Zadarskom s obvezom sadnje vinograda i maslinika ${ }^{55}$ te 1807 . godine don Šimi Blasulu iz Kali i njegovoj obitelji neke zemlje oko Dračevca Zadarskog. ${ }^{56} \mathrm{Na}$ Dugom otoku u listopadu 1801. godine potpisao je Calvi ugovor s Šimom Orlićem iz Sali kojemu je ustupio komad zemlje uz obvezu podizanja vinograda u tri godine. ${ }^{57}$

46 Liber I, 4.

47 Liber II, 90. Regalia ili honorancija podrazumijeva darivanje u naravi redovito o Božiću ili Uskrsu. U izvorima se navodi da su ih kmetovi bili dužni podavati prema starom običaju. Usp. Tomislav Raukar, Ivo Petricioli, Franjo Švelec, Šime Peričić, Zadar pod mletačkom upravom 14091797, Zadar, 1987., 252.

48 Liber I, 61.

49 Liber II, 179.

50 Liber III, 21.

51 Liber I, 86.

$52 \quad$ Liber II, 7.

53 Liber II, 53. Calvi je te terene sudskim putem zatražio natrag 15. travnja 1804. godine od baštinika Reggio jer dvije godine nisu plaćali najam niti podavali dominikal, što je odobrio C. k. Prizivni sud u Zadru 29. svibnja 1804. godine. Liber II, 179.

54 Liber II, 35.

55 Liber II, 165.

56 Liber III, 44.

57 Liber II, 141. 
Glagoljaškom sjemeništu pripadala je i dvojna kuća u Širokoj ulici (Cale Larga) u Zadru, smještena nasuprot samostana sv. Katarine, koja se iznajmljivala dijelom gospođi Margariti Salamon, udovi Gianacchi, za 12 lira $^{58}$ i kanoniku Antunu Pasqualiju Pimi i njegovu bratu Trifunu za 74 lire i 8 soldi godišnje. ${ }^{59}$

O sjemenišnim maslinicima, vinogradima i oranicama u Brbinju brigu su vodili gastaldi Šime Bolonja te kasnije Petar Brunac, a o onima u Savru Martin i Šime Letinić. ${ }^{60}$ Gastalde u Brbinju i Savru najčešće se plaćalo iz dijela prikupljenog dominikala, a tek rjeđe novcem. Don Gašpar Sikirić vodio je brigu o sjemenišnim posjedima u Bibinju i Dračevcu Zadarskom, a kao gastald za svoju službu primao je plaću od 96 lira godišnje. ${ }^{61}$ Obnašao je i službu sakupljača crkvene desetine. ${ }^{62}$ Njega je 1795. godine u službi gastalda zamijenio Jakov Petković iz Bibinja uz godišnju plaću od 144 lire. Dužnost gastalda bila je pobrinuti se za pravedno podavanje $1 / 4$ dominikala sjemeništu od svih proizvoda. ${ }^{63} \mathrm{Uz}$ gastalda sjemenište je nerijetko plaćalo i čuvare vinograda, osobito prije berbe. ${ }^{64}$

Česti su zapisi o sudskim procesima koje je glagoljaško sjemenište za Calvijeva upravljanja vodilo preko zastupnika odvjetnika Petra Filipija i Petra Addobbatija. Najčešći uzroci tih procesa bili su neplaćanje najamnine, ${ }^{65}$ dominikala, ${ }^{66}$ nepoštovanje kolonatskih obveza ${ }^{67}$ ili uzurpacije sjemenišnih zemljišta. ${ }^{68} \mathrm{U}$ takvim slučajevima tražilo se podmirenje duga i raskid ugovora, a zemlja se vraćala $u$ ruke glagoljaškog sjemeništa. ${ }^{69}$ Prvi zabilježen spor $u$ Calvijevo vrijeme vodio se protiv Karla Pičinića i nekih Malološinjana zbog štete

58 Liber I, 63.

59 Nadbiskup Carsana u svom izvješću generalnom providuru Francescu Valieru 29. travnja 1785. godine navodi da sjemenište posjeduje 4 kuće u gradu, ali u zapisima rektora Calvija upisani su prihodi samo ovdje navedenih kuća. Usp. HR-AZDN-16/1, Zadarska nadbiskupija/Metropolija, Registrum litterarum, Dopisivanje zadarskih nadbiskupa: Carsana, 1774. - 1790., knj. 1, 29. travnja 1785. godine.

60 Liber I, 6; 95.

61 Liber $1,78$.

62 Liber I, 63.

63 Liber II, 54.

${ }^{64}$ Primjerice, koncem 18. i početkom 19. stoljeća čuvar vinograda na kopnu (Bibinje i Dračevac Zadarski) bio je Roko Lukić iz Bibinja, a sjemenište mu je za to dalo 3 barila vina u vrijednosti 72 lire, što znači da se baril vina tada cijenio 24 lire. Liber II, 177.

65 Liber III, 8.

66 Liber II, 179.

67 Liber I, 94.

68 U svibnju 1782. godine tužio je Calvi rođake Antu, Franu i Matu Frletu iz Bibinja zbog uzurpiranja sjemenišne zemlje na lokalitetu zvanom Svrdlo (Suerdlo) u Bibinjskom polju. Liber I, 5; 8.

69 Liber II, 179. 
počinjene na sjemenišnim pašnjacima na otoku Maunu. ${ }^{70}$ Nerijetko su se vodili sporovi protiv mještana Sali na Dugom otoku zbog sječe i krađe sjemenišne šume. Primjerice, 1794. godine javni procjenitelji Dume Dukić i Petar Tičina utvrdili su štetu u iznosu od 24.5 cekina. ${ }^{71}$ Štoviše, 1795 . godine Calvi zapisuje da je šuma u Telašćici u potpunosti uništena te je od 23. studenoga 1794. do 8. srpnja 1795. godine prevezeno 16 barki i jedan leut drva s toga područja, a na kaznenom sudu (Criminale Pretorio) pokrenut je proces protiv Marka Petrakovića (Petracov) iz Sali koji je osumnjičen za krađu. ${ }^{72}$ No, 1804 . godine Calvi zapisuje da nisu pronađeni svi krivci za štetu počinjenu u Telašćici. ${ }^{73}$ Šumu u Telašćici bespravno su sjekli i Prvićani, pa se protiv najmitelja Šešelje i Žampjere pokrenuo spor zbog nemara u čuvanju sjemenišnog posjeda. ${ }^{74}$ Zabilježeni su česti sudski procesi protiv mještana Brbinja i Savra zbog nezakonite sječe drva, ${ }^{75}$ a navodi se podatak da je mletačka vlast naredila pomor koza u tim mjestima zbog štete koju su nanosili poljoprivrednim kulturama. ${ }^{76}$ Nerijetke su tužbe i prigovori na mještane Bibinja, Crnoga i Dračevca zbog šteta počinjenih nad sjemenišnim vinogradima i maslinicima. ${ }^{77}$ Vodio se protiv njih i spor zbog nepoštivanja čuvara sjemenišnih vinograda na tom području, ${ }^{78}$ a tada je to bio Stipe Karaban iz Bibinja. ${ }^{79}$ Nadalje, vodili su se sudski procesi protiv nekih pastira koji su nezakonito napasali stoku na pašnjacima Telašćice. ${ }^{80} \mathrm{I}$ zbog nadarbine Sv. Petra u Osoru vodilo je sjemenište sudski proces na pritužbu osorskog biskupa Šimuna Spalatina $(1781 .-1798 \text {. })^{81}$ zbog ispaše stoke na sjemenišnim pašnjacima otoka Unije, sječe drva i drugih počinjenih materijalnih šteta. ${ }^{82}$ Sudski procesi, odvjetnici i ovjera dokumenata kod zadarskih bilježnika utjecali su na rashode glagoljaškog sjemeništa, a nerijetko se na naplatu dugovanja čekalo godinama.

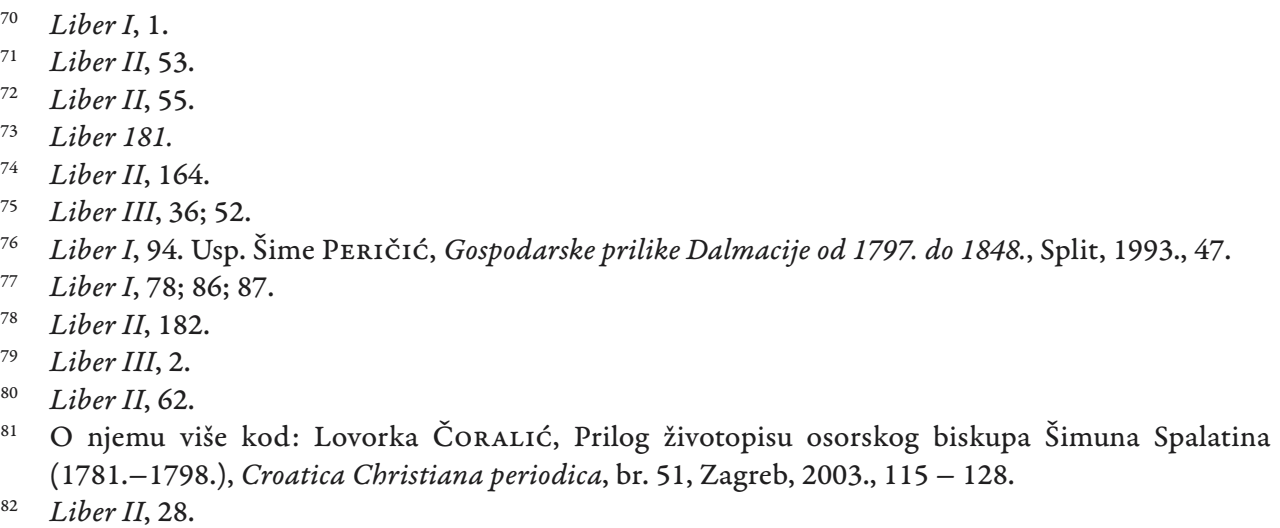


Jedna od obveza glagoljaškog sjemeništa bilo je i održavanje crkava i nekretnina pod naslovom pripojenih nadarbina. ${ }^{83}$ Česti su stoga zapisi u Calvijevim knjigama o troškovima obnova. ${ }^{84}$

\section{PRERADA GROŽĐA, MASLINA I RATARSKIH KULTURA}

Proizvodnja vina i maslinova ulja bila je okosnicom života u Dalmaciji koncem 18. i početkom 19. stoljeća ${ }^{85} \mathrm{Ne}$ čudi stoga da se osobita pozornost davala uzgajanju vinove loze i maslina i na crkvenim zemljištima, pa tako i na nadarbinama glagoljaškog sjemeništa u Zadru. Nakon smrti posljednjeg komendatora nadarbine sv. Krševana glagoljaško sjemenište ušlo je u njezin posjed. Radi usporedbe prinosa i prihoda u vrijeme Calvijeva upravljanja sjemeništem tablično se prikazuju posjedi, poljoprivredne kulture i prosječni godišnji prihodi nadarbina samostana sv. Krševana u Zadru i sv. Petra u Osoru do otvorenja glagoljaškog sjemeništa 1748. godine (Tablica 2 i 3 ).

TABlica 2. Popis dobara, poljoprivrednih kultura i prosječnih godišnjih prihoda nadarbine samostana sv. Krševana do 1748. godine

\begin{tabular}{|l|c|c|c|}
\hline \multicolumn{1}{|c|}{ Dobra/kulture } & Količina & Tržišna cijena & Prihod \\
\hline Žitarice i grahorice & 80 zadarskih kvarti & 32 lire po kvarti & 2560 lira \\
\hline Vino & 250 barila & 13 lira po barilu & 3250 lira \\
\hline Maslinovo ulje & 12 barila & 120 lira po barilu & 1440 lira \\
\hline Rakija & - & - & 300 lira \\
\hline Posjedi u Telašćici & - & - & 640 lira \\
\hline Sitna stoka i pašnjak u Telašćići & 560 ovaca i koza & - & 870 lira \\
\hline Šuma i pašnjak Gračine & - & - & 100 lira \\
\hline Pašnjaci na otoku Maunu & - & - & 750 lira \\
\hline $\begin{array}{l}\text { Konoba i skladište u Zadru (Cassa } \\
\text { Abbaziale) }\end{array}$ & - & - & 240 lira \\
\hline Liveli 4 kuća u Zadru i van grada & - & - & 175 lira \\
\hline \multicolumn{2}{|c|}{ Sveukupno prosječni godišnji prihodi nadarbine } & 10295 lira \\
\hline
\end{tabular}

Izvor: HR-DAZD-336, Benediktinski samostan Sv. Krševana, kut. 5, svež. 1.5.7., fol. 86v.

83 Usp. HR-DAZD-336, Benediktinski samostan sv. Krševana, kut. 4, svež. 1.5.1., fol. 215v.

84 U prilogu se donosi prijepis izvješća obnove krovišta na crkvi sv. Krševana iz 1792. godine kao doprinos poznavanju arhitekture i umjetničke baštine samostana sv. Krševana u Zadru tijekom 18. i početkom 19. stoljeća (Prilog 2). Posao obnove krovišta vodio je zadarski poslovođa (Proto) Antonio Bernardini, koji je 1780.-1781. godine obnovio krovište zadarske katedrale. HRDAZD-31, Bilježnici Zadra, Donato Antonio Ferrari, 1774. - 1796., b. I, svež. 7, fol. 7r-8v.

85 Usp. Šime PERIČIĆ, Razvitak gospodarstva Zadra i okolice u prošlosti, Zagreb-Zadar, 1999., 69 - 79; 139-147; Š. PERIČIĆ, Gospodarske prilike Dalmacije, 22 - 31. 
TABlica 3. Popis dobara, poljoprivrednih kultura i prosječnih godišnjih prihoda nadarbine samostana sv. Petra u Osoru do 1748. godine

\begin{tabular}{|l|c|l|c|}
\hline \multicolumn{1}{|c|}{ Dobra/kulture } & Količina & Tržišna cijena & Prihod \\
\hline Otok Unije i Male Srakane & - & - & 1200 lira \\
\hline Stancija Matalada (otok Cres) & 727 ovaca & - & 550 lira \\
\hline $\begin{array}{l}\text { Dva vrta u Osoru u Ulici sv. Petra i } \\
\text { sv. Katarine }\end{array}$ & - & - & 55 lira \\
\hline Vinograd u luci & - & - & 74 lire \\
\hline $\begin{array}{l}\text { Teren Fabrike pod vinogradom u } \\
\text { Nerezinama }\end{array}$ & - & - & 44 lire \\
\hline $\begin{array}{l}\text { Teren zvan Opatija (šuma i pašnjak) } \\
\text { u Potoku na punti Križ }\end{array}$ & - & - & 36 lira \\
\hline $\begin{array}{l}\text { Šuma na punti Ćunski i pašnjak na } \\
\text { punti Križ }\end{array}$ & - & - & 40 lira \\
\hline $\begin{array}{l}\text { Stancija Prantur (šuma, pašnjak, } \\
\text { oranica i vinograd) }\end{array}$ & - & - & 132 lire \\
\hline $\begin{array}{l}\text { Tršić (Lošinj) - Velo Polje - } \\
\text { vinograd }\end{array}$ & - & - & 110 lira \\
\hline Šuma Opatija u Nerezinama & - & - & 13 lira \\
\hline Dvije oranice u Medulinu u Istri & $\begin{array}{l}\text { pola stara pšenice } \\
\text { godišnje za najam }\end{array}$ & $\begin{array}{l}16 \text { lira star } \\
\text { pšenice }\end{array}$ \\
\hline Šumoviti teren Fusichievo - Nerezine & - & - & 2276 lira \\
\hline Sveukupno prosječni godišnji prihodi nadarbine & & 86 lira \\
\hline
\end{tabular}

Izvor: HR-DAZD-336, Benediktinski samostan Sv. Krševana, kut. 5, svež. 1.5.7., fol. 86v.

Od prosječnih godišnjih prihoda nadarbine samostana sv. Krševana do 1748 . godine izdvajalo se 2036 lira i 4 solda za troškove, a trećina prihoda od 2752 lire i 18 soldi pripadala je crkvi sv. Krševana, ${ }^{86}$ a godišnji troškovi nadarbine Sv. Petra iznosili su 676 lira i 3 solda. ${ }^{87}$

Najveći broj vinograda na posjedima glagoljaškog sjemeništa u Zadru u razmatranom razdoblju nalazio se u Brbinju i Savru na Dugom otoku te u Bibinjama i Dračevcu Zadarskom. Sjemenište je bilo u posjedu velikog vinskog

86 HR-DAZD-336, Benediktinski samostan Sv. Krševana, kut. 5, svež. 1.5.7., fol. 86v

87 U te troškove spadale su desetina mletačkoj magistraturi Decime del Clero (489 lira i 7 soldi), 96 svetih misa (76 lira i 16 soldi) osorskom kaptolu za pjevanu misu, I. i II. Večernju uoči svetkovine sv. Petra (15 lira), upravitelju opatije $2 \%$ (45 lira) te za održavanje svjetiljki u crkvi i ulje (10 lira). HR-DAZD-336, Benediktinski samostan Sv. Krševana, kut. 5, svež. 1.5.7., fol. 87r. 
podruma (konobe) u blizini gradskih lučkih vrata (Porta Marina) u Zadru ${ }^{88}$ koji je nekada pripadao samostanu sv. Krševana (Caneva dell'Abbazia). ${ }^{89}$ Ponekad se taj podrum iznajmljivao za prodaju vina po 24 lire mjesečno. ${ }^{90}$ Iznad konobe nalazilo se skladište koje se redovito davalo u najam. ${ }^{11}$ Upravitelj i najmitelj vinskog podruma bio je bačvar (bottaro) Mate Brunac. ${ }^{92}$ Berba grožđa redovito se obavljala od početka rujna do konca listopada. Grožđe iz Bibinja i Dračevca Zadarskog te mošt $\mathrm{s}$ Dugog otoka prevozio se leutima do zadarske luke u koslatama različite nosivosti. ${ }^{93} \mathrm{O}$ tom poslu često se spominje ime don Šime Odvitovića zvanog Bacalja (Baccaglia) čijim se leutom prevozio mošt za sjemenište, ${ }^{94}$ a 1803. godine spominje se o tom poslu i don Marko Uglešić iz Božave. ${ }^{95} \mathrm{U}$ vrijeme Calvijeva upravljanja glagoljaškim sjemeništem brigu o pripremanju vina u sjemenišnom vinskom podrumu vodio je Ante Dužić iz Velog Rata, u čemu su mu pomagali sin Mate, kći te jedan pomoćnik. Za svoj posao primao je naknadu u visini 30 lira. ${ }^{96}$ U boljim godinama berbe bilježi se prodaja sjemenišnog vina tijekom mjeseca lipnja, što upućuje na zaključak da se vinski podrum dobro održavao i da su se rabile bačve bolje kvalitete. ${ }^{97}$ Unatoč toj činjenici, nerijetki su i zapisi o kiselom i pljesnivom vinu u razmatranom razdoblju. Količina proizvedenog i prodavanog vina izražavala se u barilima, sićima, bokalima i kvartučima. ${ }^{98}$ Prema dostupnim podatcima, u vrijeme Calvijeva upravljanja glagoljaškim sjemeništem prosječno se godišnje proizvelo 76,3 barila vina iz vinograda na Dugom otoku, a 81,5 barila vina iz vinograda u Bibinju i Dračevcu Zadarskom. Sjemenišne bačve držale su oko 20 barila vina. Vino slabije kvalitete se prodavalo, a jedna do dvije bačve zdravog vina ostavljale su se za sjemenišne potrebe ovisno o urodu i kvaliteti

89 Liber $I, 1$.

90 U kolovozu 1782. godine podrum je iznajmio Felice Brutti iz Napulja za prodaju di alcune Botte di Vino di sua specialità. Liber I, 8.

91 Liber I, 39.

92 Liber I, 55.

93 Liber I, 70; 80. Koslata je bila posuda većeg obujma pa se ne uzima kao određena mjera. Usp. Marija Zaninović-Rumora, Stare mjere u svakodnevlju otoka Ugljana, Radovi Zavoda za povijesne znanosti HAZU u Zadru, br. 41, Zadar, 1999., 22.

94 Liber $I, 80$.

95 Liber II, 168.

96 Liber I, 80; Liber II, 13.

97 Liber I, 68; 85. Usp. Š. PeRIČIĆ, Gospodarske prilike Dalmacije, 26.

98 O nosivosti tih mjera vidi: Marija Zaninović-Rumora, Stare mjere za tekućine, Radovi Zavoda za povijesne znanosti HAZU u Zadru, br. 39, Zadar, 1997., 183 - 187; Š. PERIČIĆ, Razvitak gospodarstva Zadra, 280; Josip Kolanović, Šibenski metrološki sustav u XV. stoljeću, Arbivski vjesnik, br. 37, Zagreb, 1994., str. 198, bilj. 38. 
grožđa određene godine. U slučaju manjka vina za sjemenišne potrebe ono se kupovalo, primjerice od zadarskih franjevaca. ${ }^{99}$ Zamjetno je da se bolje vino dobivalo iz grožđa s posjeda u Bibinjama i Dračevcu Zadarskom koje je sano e perfetto, ${ }^{100}$ a lošije s Dugog otoka. ${ }^{101}$ Kvaliteta vina utjecala je i na prodajnu cijenu. Tako se vino iz Bibinja i Dračevca Zadarskog prodavalo po 8 - 12 soldi po kvartuču, a ono s Dugog otoka po 6 - 10 soldi po kvartuču. ${ }^{102}$ No i druge okolnosti utjecale su na cijenu vina. Primjerice, 1786. godine vino se prodavalo po maloj cijeni jer ga je bilo u izobilju u cijeloj pokrajini. Uz to, tada su predstavnici mletačke vlasti već 10 mjeseci bili odsutni iz grada, a vojska prebačena u Kotor zbog uznemiravanja skadarskog paše, ${ }^{103}$ pa je izostala prodaja vina vojnicima. ${ }^{104}$ Vino su redovite prodavale žene u bokalima na malo (alla minuta) ili na pipu (alla spina). ${ }^{105} \mathrm{Za}$ svoj posao dobivale su 6 lira po prodanoj bačvi vina (20 barila) i dnevnicu za ručak. ${ }^{106}$ Primjerice, 1782. godine Kata, sluškinja u Sv. Dimitriju, prodala je 20 barila sjemenišnog vina po cijeni od 31 lire i 10 soldi po barilu, a za uslugu joj je sjemenište platilo 6 lira. ${ }^{107} \mathrm{Na}$ proizvedeno i prodano vino državi se plaćao redoviti porez. ${ }^{108}$ Primjerice, za prodaju vina na pipu (alla spina) porez je iznosio 30 lira godišnje. ${ }^{109}$ Vino se prodavalo i zadarskom kaptolu, Florijevu sjemeništu, a pljesnivo i kiselo vino (vin muffa e guasto) zadarskim trgovcima. ${ }^{110}$ Godine 1794. pristupilo se destilaciji grožđa i proizvodnji rakije (racchia; acquavita). ${ }^{111}$ Grožđe je u svojoj kući destilirao Franjo Livaković, otac svećenika Šime, a za plaću mu se ostavljalo pola proizvedene rakije. ${ }^{112}$

Calvi je zapisivao i vremenske nepogode koje su utjecale na sjemenišne prihode, primjerice 1808. godine na Brbinju i Savru berba je podbacila jer je jaka oluja $s$ grädom potukla plod pa je te godine prinos vina s Dugog otoka iznosio samo 40 barila. $^{113}$

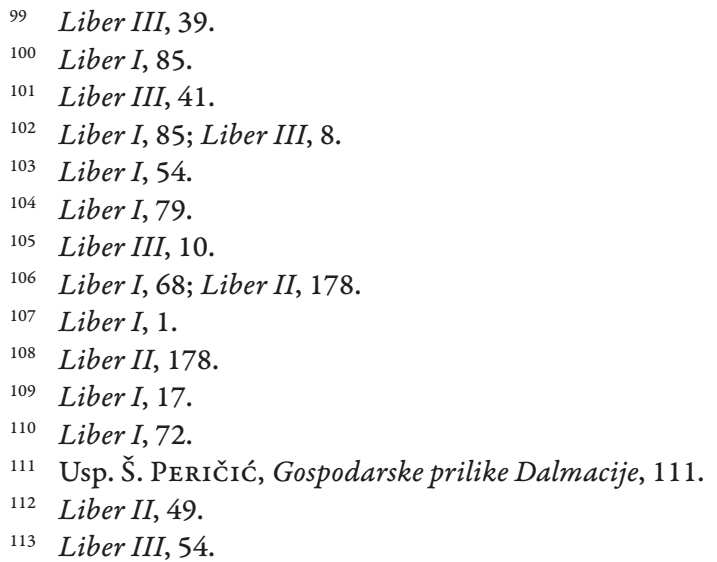


Tablica 4. Prinos vina od 1783. do 1810. s Dugog otoka (Brbinj i Savar) te Bibinja i Dračevca (Terraferma) izražen u barilima

\begin{tabular}{|c|c|c|}
\hline Godina & Brbinj i Savar & Bibinje i Dračevac \\
\hline 1782. & 80 & 60 \\
\hline 1783. & - & - \\
\hline 1784. & 60 & 60 \\
\hline 1785. & 120 & 120 \\
\hline 1786. & 140 & 100 \\
\hline 1787. & 80 & 62,5 \\
\hline 1788. & 80 & 100 \\
\hline 1789. & 100 & 120 \\
\hline 1790. & 80 & 100 \\
\hline 1791. & 80 & 100 \\
\hline 1792. & 70 & 60 \\
\hline 1793. & - & - \\
\hline 1794. & 90 & 80 \\
\hline 1795. & 80 & 50 \\
\hline 1796. & 80 & 60 \\
\hline 1797. & 80 & 60 \\
\hline 1798. & 60 & 60 \\
\hline 1799. & 60 & 40 \\
\hline 1800. & - & - \\
\hline 1801. & 20 & 40 \\
\hline 1802. & 20 & 60 \\
\hline 1803. & 40 & 140 \\
\hline 1804. & - & - \\
\hline 1805. & 160 & 120 \\
\hline 1806. & - & - \\
\hline 1807. & 60 & 80 \\
\hline 1808. & 40 & 120 \\
\hline 1809. & - & - \\
\hline 1810. & - & - \\
\hline
\end{tabular}


Konstantna briga oko nasada maslina i njihova uzgoja na sjemenišnim posjedima u razmatranom razdoblju pokazatelj su važnosti i vrijednosti te voćke u Dalmaciji koncem 18. i početkom 19. stoljeća. ${ }^{114}$ Maslinici glagoljaškog sjemeništa nalazili su se, kao i vinogradi, na Dugom otoku i na području Bibinja i Dračevca Zadarskog. U prosjeku je glagoljaško sjemenište godišnje proizvodilo oko 10 barila, 4 sića i 27 kvartuča ulja, kako proizlazi iz dostupnih podataka rektora Calvija. Redovito se prije berbe pristupalo procjeni uroda maslina što su činili gastaldi sjemenišnih posjeda ili procjenitelji iz grada, ${ }^{115}$ a za svoj posao bili su plaćeni 5 lira po danu. ${ }^{116}$ Usporedbom njihove procjene i konačnog broja pobranih maslina razvidno je da su bili upućeni u posao jer je točnost procjene varirala između 96 i $98 \% .{ }^{117}$ Suprotno vinu, prihod maslinova ulja bio je bolji s posjeda na Dugom otoku, zbog čega je glagoljaško sjemenište 1794. godine pribavilo za svoj mlin u Brbinju novi, moderniji tijesak (torcolo) za ulje kojim je, prema Calvijevim riječima, mogao upravljati samo jedan čovjek, a prinos ulja od iscijeđenih maslina bio je veći za $24-25 \%{ }^{118}$ Brigu oko mlina i novog tijeska za Calvijeva upravljanja glagoljaškim sjemeništem vodio je Josip Rančić iz Brbinja, a sjemenište mu je za to plaćalo 28 lira i 16 soldi. ${ }^{119}$ Redovito održavanje i popravak novog tijeska povjeren je mistru (majstoru) Bernardinu Deganellu iz Zadra. ${ }^{120}$ Cjeloviti prikaz oko nabavke i izgradnje novog tijeska zapisao je rektor Calvi u računskim knjigama. ${ }^{121}$

Iz računskih knjiga glagoljaškog sjemeništa u Zadru moguće je saznati i neke ekonomske aspekte prerade maslina u to vrijeme. Masline i ulje prevozili su se brodovima čiji se najam plaćao 10 lira po danu za barku, a 13 lira za leut. Mornarima se isplaćivalo 3 lire po danu. ${ }^{122}$ Prijevoz maslina iz gradske luke do mlina naplaćivao se 2 solda po četvrtalju. ${ }^{123}$ Masline sa sjemenišnih posjeda redovito su se prevozile u zadarske mlinove Franje Ruste i baštinika Stocco, ${ }^{124}$ a

114 Usp. Š. Peričić, Gospodarske prilike Dalmacije, 27 - 31.

115 Često se o tom poslu u Calvijevim zapisima spominju Varošani Božo Dujela i Šime Jelenić. Liber I, 61; Liber III, 14.

116 Liber I, 48.

117 Liber I, 81; Liber II, 89; 111.

118 Liber II, 38. Stariji torkul radio je na principu poznatih starih rimskih torkula. Usp. Boris ILA KovaC, Rekonstrukcija rimskog tijeska za masline u Mulinama na otoku Ugljanu, Radovi Zavoda za povijesne znanosti HAZU u Zadru, br. 40, Zadar, 1998., 1 - 26.

119 Liber II, 88.

120 Liber II, 112.

121 Prijepis prikaza nabave i izgradnje novog tijeska u Brbinju donosi se u prilogu (Prilog 3).

122 Liber I, 64.

123 Liber I, 66.

124 Liber I, 66; Liber II, 14. Capo Mistro u mlinu Stocco u to je vrijeme bio Stipe Bilović. Liber II, 27. 
rjeđe su se, uglavnom u godini slabog uroda, mljele u mlinu opatica samostana sv. Marije u Zadru, ${ }^{125}$ a tek ponekad u zadarskom mlinu Galeno, ${ }^{126}$ što potvrđuje zaključak Š. Peričića da su vlasnice tih mlinova za mletačke uprave bile uglavnom plemićke obitelji i crkvene ustanove. ${ }^{127}$ Troškovi meljave maslina u zadarskim mlinovima koncem 18. stoljeća iznosili su kako slijedi: al capo Mistro de Molin = 4 lire dnevno; al secondo Mistr $=3$ lire i 10 soldi dnevno; trojici radnika = po 3 lire dnevno; rakija u vrijednosti 10 soldi ujutro; boca vina nakon ručka; prijevoz ulja do sjemenišnih kamenica 2 lire. ${ }^{128}$

Vlasniku mlina plaćalo se u ulju, i to u omjeru 3 kvartuča po barilu dobivenog ulja, a ostatak tijesta od koštica (ossi; morga) velike energetske vrijednosti prodavao se bilo vlasniku mlina za ogrjev ili zadarskim pekarima za potrebe krušnih peći. ${ }^{129}$ Sjemenište je posjedovalo jednu kamenicu za ulje u Brbinju od 8 barila nosivosti i dvije kamenice za ulje u sjemenišnoj konobi ${ }^{130}$ koje su se redovito održavale i prale lužinom (luzini, otopinom pepela ili luga). ${ }^{131} \mathrm{O}$ dobrom stanju kamenice ovisilo je i očuvanje ulja pa bi se u slučaju užeglosti ona redovito oklesala. ${ }^{132}$ Kao i za vino, državi se plaćao porez na ulje. ${ }^{133} \mathrm{Od}$ anomalija tijekom berbe maslina Calvi je zabilježio veliku studen 1782 . godine zbog koje se pristupilo sječi neplodnih stabala i čije su se posljedice protezale sve do 1785 . godine; ${ }^{134}$ zbog lijepa vremena i zrelosti maslina 1786. godine meljava je obavljena početkom veljače; ${ }^{135} 1788$. godine masline na Dugom otoku napao je crv (vermo), ${ }^{136}$ a 1799. godine masline u Brbinju i Savru uopće nisu donijele ploda. ${ }^{137} \mathrm{U}$ slučaju pomanjkanja ulja za svakodnevne potrebe ono se kupovalo po cijeni od 2 lire i 8 soldi po kvartuču. ${ }^{138} \mathrm{U}$ vrijeme nestašice ulja, primjerice 1793. godine kada je zabilježen manjak ulja u Zadru, kupovalo se staro kvalitetno

Liber II, 103.

Liber I, 92.

Usp. Š. PERIČIĆ, Razvitak gospodarstva Zadra, 98.

128 Liber I, 66; 92.

129 Liber I, 66.

130 Liber II, 45.

131 Liber II, 119.

132 Liber II, 45.

133 Liber III, 67.

134 Liber I, 18. Usp. Grozdana Franov-ŽIv ković, Život i djelo glagoljaša don Jerolima Kuzmića Šimića (Župa Sutomišćica, oko 1726. - 4. 12. 1793.), Croatica Christiana periodica, br. 75, Zagreb, 2015., 92.

135 Liber I, 51.

136 Liber II, 82.

137 Liber II, 103.

138 Liber I, 64. 
ulje po visokim cijenama. ${ }^{139}$ Viškove proizvedenog ulja sjemenište je redovito prodavalo katedralnom crkovinarstvu u Zadru po cijeni od 234 lire po barilu. ${ }^{140}$

TABLICA 5. Prinos maslinova ulja od 1784. do 1810. izražen u barilima, sićima $i$ kvartučima

\begin{tabular}{|c|c|c|c|}
\hline Godina & Barila & Sića & Kvartuča \\
\hline 1784. & 5 & 1 & - \\
\hline 1785. & 2 & 1 & - \\
\hline 1786. & - & 13 & - \\
\hline 1787. & 7 & 3 & 4 \\
\hline 1788. & 7 & - & - \\
\hline 1789. & 12 & - & - \\
\hline 1790. & - & - & - \\
\hline 1791. & 12 & - & - \\
\hline 1792. & 2 & - & 8 \\
\hline 1793. & - & - & - \\
\hline 1794. & 33 & 2 & - \\
\hline 1795. & - & - & - \\
\hline 1796. & 5 & 6 & - \\
\hline 1797. & - & - & - \\
\hline 1798. & 11 & - & - \\
\hline 1799. & - & 5 & 5 \\
\hline 1800. & 20 & - & 10 \\
\hline 1801. & - & - & - \\
\hline 1802. & - & - & - \\
\hline 1803. & - & - & - \\
\hline 1804. & 6 & 1 & - \\
\hline 1805. & 8 & - & - \\
\hline 1806. & 15 & - & - \\
\hline 1807. & 4 & 2 & - \\
\hline 1808. & 8 & 2 & - \\
\hline 1809. & 15 & - & - \\
\hline 1810. & - & - & - \\
\hline
\end{tabular}

139 Tada su dvojica đaka poslana barkom u Sukošan kod Mate Sudinje gdje su kupili 1 baril ulja za 318 lira. Liber II, 36.

140 Liber II, $11 ; 67$. 
Od ratarskih kultura najčešće se na sjemenišnim posjedima uzgajao ječam, pšenica, grah, bob, krupnik, raž, proso, crveni sijerak, leća i jari grah. Njihove količine u računskim knjigama izražene su u četvrtaljima (Quartta), polučacima i okama. ${ }^{141}$ No, u izvješću nadbiskupa Carsane od 1770. godine navodi se da je u Brbinju (nel Monte Petroso) 15 kampa zasađeno krumpirom (zappetta), ${ }^{142}$ što pokazuje da je sjemenišno gospodarstvo išlo u korak ili čak i prednjačilo u pogledu uvođenja novih poljoprivrednih kultura u Dalmaciji. ${ }^{143}$ Kao i u ostatku Dalmacije, i ovdje su se proizvodile male količine ratarskih kultura od kojih je pšenica zauzimala najbitnije mjesto i koju se najčešće kupovalo za svakidašnje potrebe glagoljaškog sjemeništa. ${ }^{144}$ Prije žetve redovito su ekonom ili rektor odlazili prebrojati zasijana polja radi kontrole prinosa i utvrđivanja iznosa dominikala. ${ }^{145}$ Prikupljenu pšenicu i ječam, nakon vršidbe na seoskim gumnima (l'Ara), ${ }^{146}$ prevozilo se brodovima u Zadar, a nakon čišćenja i pranja u maštelima slala se morskim putem najčešće do skradinskih ${ }^{147}$ i trogirskih mlinova, ${ }^{148} \mathrm{~s}$ obzirom na to da je zadarsko zaleđe oskudijevalo vodenim tokovima, ${ }^{149}$ dok su se manje količine za svakodnevne potrebe mljele ručno u gradu. ${ }^{150}$ Brašno se čuvalo u drvenom sanduku - kasunu (Casson Grande) pod ključem. ${ }^{151} \mathrm{Zbog}$ izolacije (contumacie) dalmatinskih gradova uzrokovane kugom u Splitu 1783. 1784. godine ${ }^{152}$ glagoljaško sjemenište nije moglo do svoga brašna iz trogirskih

141 O vrijednostima tih mjera vidi više kod: M. Zaninović-Rumora, Stare mjere u svakodnevlju otoka Ugljana, 22; Marija ZANinović-Rumora, Zadarske i šibenske mjere za težinu kroz stoljeća, Radovi Zavoda za povijesne znanosti HAZU u Zadru, br. 40, Zadar, 1998., 171; Marija ZANinovićRuMOrA, Zadarske mjere za zapremninu kroz stoljeća, Radovi Zavoda za povijesne znanosti HAZU u Zadru, br. 36, Zadar, 1994., 87 - 89; Š. PERIČIĆ, Razvitak gospodarstva Zadra, 280.

142 ASV, Sopraintendenti alle decime del Clero, Zara Campatico, b. 284., br. 4.

143 Usp. Š. PERIČIĆ, Gospodarske prilike Dalmacije, 36.

144 Usp. Š. PeričIć, Gospodarske prilike Dalmacije, 32 - 33.

145 Liber II, 32.

146 Liber II, 8; 9.

$147 \mathrm{U}$ travnju 1800. godine u skradinskom mlinu radi fra Antun, brat laik sv. Frane iz Skradina. Liber II, 119.

148 Liber I, 38; 60.

149 Usp. Š. PERIČIĆ, Razvitak gospodarstva Zadra, 97 - 98.

150 Liber I, 72.

151 Liber II, 30.

152 O tome vidi više kod: Ivo Donadini, Otac Fedele iz Zadra: Kuga u Splitu 1783. - 1784., Kulturna baština, br. 18, Split, 1988., 67-89; Znanstvena knjižnica Zadar (dalje: ZKZD), STRATICO, Gregorio, Relazioni sulla peste di Spalato nell' a. 1783-1784, sign. 28330, Ms. 838; ZKZD, Relazione della peste di Spalato dell'anno 1784 esposta in lettera dall'uffiziale N.N. ad un suo concittadino in Venezia con tavole esprimenti gli effetti del Morbo sopra i popoli che ne andarono, sign. 26401, Ms. R673. 
mlinova pa ga je bilo prisiljeno kupovati. ${ }^{153}$ Tek u srpnju 1784. godine dopustile su vlasti mlinaru Ivanu Kaleboti iz Trogira ući brodom u zadarsku luku te je sjemenište, nakon pregleda zdravstvenih službi (Sanità Pubblica), ${ }^{154}$ dobilo željno očekivano brašno, ${ }^{155} \mathrm{~s}$ obzirom na to da je Calvi zapisao da je 1784. godina bila anno sterilissimo za ratarstvo, ${ }^{156} \mathrm{a}$ isto se ponovilo 1795 . godine. ${ }^{157}$ Početkom 19. stoljeća bilježi se veliki nedostatak pšenice i ulja te sukladno tomu i njihova visoka prodajna cijena. ${ }^{158}$

TABLICA 6. Poljoprivredne kulture i njihov prinos u Brbinju na Dugom otoku od 1783. do 1810. u četvrtaljima (ŕ) i okama (ok)

\begin{tabular}{|c|c|c|c|c|c|c|c|}
\hline God. & Ječam & Grah & Pšenica & Bob & $\begin{array}{c}\text { Krupnik } \\
\text { (pir) }\end{array}$ & $\begin{array}{l}\text { Jari grah } \\
\text { (sikirica) }\end{array}$ & Grahorica \\
\hline 1783. & 9 č & $1 c ̌$ & 1 č $13 \mathrm{ok}$ & - & - & - & - \\
\hline 1784. & $2,5 \mathrm{c}$ & $1 c ̌$ & $1,5 \mathrm{č}$ & - & - & - & - \\
\hline 1785. & $22 c ̌$ & $4,5 \mathrm{c}$ & $4,5 \mathrm{c}$ & $2 \check{c}$ & - & - & - \\
\hline 1786. & $24 \check{c}$ & 3 č $16 \mathrm{ok}$ & $5,5 c ̌$ & - & 0,5 č & - & - \\
\hline 1787. & 27,5 č & 4 č $140 \mathrm{ok}$ & 4 č $11 \mathrm{ok}$ & 3 č 9ok & 1ok & 5ok & 6ok \\
\hline 1788. & $14 \mathrm{c}$ & $5.5 c ̌$ & $4 \check{c}$ & $4.5 \mathrm{c}$ & - & - & - \\
\hline 1789. & $15 c ̌$ & 3 č $15 \mathrm{ok}$ & $4 c ̌$ & $1 c ̌ 11 \mathrm{ok}$ & 3ok & - & $4 \mathrm{ok}$ \\
\hline 1790. & $21 \mathrm{č} 11 \mathrm{ok}$ & 5 č $60 \mathrm{k}$ & $4 \check{c} 9$ ok & $1 \mathrm{č} 4 \mathrm{ok}$ & - & - & \\
\hline 1791. & $38 \mathrm{c} 9 \mathrm{ok}$ & 9č 9ok & $6 c ̌ 11 \mathrm{ok}$ & 2 č $9 \mathrm{ok}$ & - & - & $1 \mathrm{c} 6 \mathrm{ok}$ \\
\hline 1792. & 20 č & $6 \check{c}$ & $5 c ̌$ & 2č 9ok & - & - & - \\
\hline 1793. & 32 č $9 \mathrm{ok}$ & $5 c ̌$ & $5 c ̌$ & 2 č $9 \mathrm{ok}$ & 3ok & - & - \\
\hline 1794. & $3 c ̌ 5 o k$ & - & - & - & - & - & - \\
\hline 1795. & 23 č 9ok & $9 \mathrm{ok}$ & $3 \check{c}$ & 9ok & - & - & - \\
\hline
\end{tabular}

153 Liber I, 32.

154 U zadarskoj luci od 1679. godine postojao je Zdravstveni ured. Š. PERIČıć, Razvitak gospodarstva Zadra, 120.

155 Liber I, 33.

156 Liber II, 48.

157 Liber II, 54.

158 Usp. Š. PERIČIĆ, Razvitak gospodarstva Zadra, 132. 


\begin{tabular}{|c|c|c|c|c|c|c|c|}
\hline God. & Ječam & Grah & Pšenica & Bob & $\begin{array}{c}\text { Krupnik } \\
\text { (pir) }\end{array}$ & $\begin{array}{l}\text { Jari grah } \\
\text { (sikirica) }\end{array}$ & Grahorica \\
\hline 1796. & 17č 9ok & $3 c ̌ 1 o k$ & 5 č 3ok & - & - & - & - \\
\hline 1797. & 19.5 č & $1 c ̌ 12 \mathrm{ok}$ & 2 č $16 \mathrm{ok}$ & 1č 9 ok & - & - & - \\
\hline 1798. & $22 \check{c}$ & 1 č $17 \mathrm{ok}$ & 4 č $11 \mathrm{ok}$ & 1 č $7 \mathrm{ok}$ & - & - & 1 č $2 \mathrm{ok}$ \\
\hline 1799. & 40 č & $6 \mathrm{č} 1 \mathrm{ok}$ & $6 c ̌$ 8ok & 9ok & - & - & \\
\hline 1800. & 19 č & 2 č $2 \mathrm{ok}$ & $2 c ̌ s o k$ & $11 \mathrm{ok}$ & - & - & - \\
\hline 1801. & 17 č 9 ok & 1 č $12 \mathrm{ok}$ & 2 č $3 \mathrm{ok}$ & $7 \mathrm{ok}$ & - & - & 5ok \\
\hline 1802. & $10 c ̌$ & - & $1 c ̌$ & - & - & - & - \\
\hline 1803. & 13 č $17 \mathrm{ok}$ & - & $2 c ̌$ & - & - & - & - \\
\hline 1804. & $13 c ̌$ & $1 c ̌$ & 3 č 9 ok & - & - & - & - \\
\hline 1805. & $30 c ̌$ & 2 č 9 ok & $4 \check{c}$ & - & - & - & - \\
\hline 1806. & 18 č $9 \mathrm{ok}$ & $2 c ̌$ & $17 \mathrm{ok}$ & - & - & - & - \\
\hline 1807. & $18 \mathrm{c}$ & $50 \mathrm{k}$ & 2 č $9 \mathrm{ok}$ & - & - & - & - \\
\hline 1808. & $13 c ̌$ & 5ok & 1 č 9 ok & - & - & - & 2ok \\
\hline 1809. & - & - & - & - & - & - & - \\
\hline 1810. & 11 č $90 \mathrm{k}$ & $1 \mathrm{č} 4 \mathrm{ok}$ & 2 č 9 ok & - & - & - & - \\
\hline
\end{tabular}

TABLICA 7. Poljoprivredne kulture i njihov prinos u Savru na Dugom otoku od 1783. do 1810. u četvrtaljima (č $)$ i okama (ok)

\begin{tabular}{|c|c|c|c|c|c|c|c|}
\hline God. & Ječam & Grah & Pšenica & Bob & $\begin{array}{l}\text { Krupnik } \\
\text { (pir })\end{array}$ & Leća & Grahorica \\
\hline 1783. & $4 \check{c} 3 \mathrm{ok}$ & $7 \mathrm{ok}$ & $2 \check{c} 6 \mathrm{ok}$ & $2 \mathrm{ok}$ & - & - & - \\
\hline 1784. & $2.5 \check{c}$ & $3 \mathrm{ok}$ & $14 \mathrm{ok}$ & $3 \mathrm{ok}$ & - & - & - \\
\hline 1785. & $8 \check{c} 8 \mathrm{ok}$ & $6 \mathrm{ok}$ & $3 \check{c}$ & $3 \mathrm{ok}$ & - & - & - \\
\hline 1786. & $4.5 \check{c}$ & $1 \mathrm{c} 7 \mathrm{ok}$ & $1.5 \check{c}$ & 1 č & - & - & \\
\hline 1787. & $7 \check{c}$ & $7 \mathrm{ok}$ & $2 \check{c}$ & $1 \check{c} 3 \mathrm{ok}$ & $1 \mathrm{ok}$ & $1 \mathrm{ok}$ & \\
\hline 1788. & $3.5 \check{c}$ & $1 \check{c} 2 \mathrm{ok}$ & $2 \check{c}$ & - & $3 \mathrm{ok}$ & $3 \mathrm{ok}$ & $3 \mathrm{ok}$ \\
\hline 1789. & $2 \check{c} 6 \mathrm{ok}$ & $9 \mathrm{ok}$ & $1 \mathrm{c} 5 \mathrm{ok}$ & $9 \mathrm{ok}$ & - & $2 \mathrm{ok}$ & - \\
\hline
\end{tabular}


Zdenko Dundović: Gospodarske prilike Zmajevićeva glagoljaškog sjemeništa u Zadru...

\begin{tabular}{|c|c|c|c|c|c|c|c|}
\hline God. & Ječam & Grah & Pšenica & Bob & \begin{tabular}{|l} 
Krupnik \\
(pir)
\end{tabular} & Leća & Grahorica \\
\hline 1790. & 1č $12 \mathrm{ok}$ & $3 o k$ & $14 \mathrm{ok}$ & - & - & lok & - \\
\hline 1791. & 10 č $2 \mathrm{ok}$ & $1 c ̌$ ook & $3 c ̌$ & 9 ok & - & 2ok & - \\
\hline 1792. & $4 c ̌ 2 o k$ & $13 \mathrm{ok}$ & - & - & - & - & - \\
\hline 1793. & $10 \check{c}$ & 6ok & 1č $12 \mathrm{ok}$ & $12 \mathrm{ok}$ & - & - & - \\
\hline 1794. & - & - & - & - & - & - & - \\
\hline 1795. & 1č 8 ok & - & $14 \mathrm{ok}$ & - & $3.5 c$ & - & - \\
\hline 1796. & 2 č $12 \mathrm{ok}$ & - & $1 c ̌$ & $11 \mathrm{ok}$ & - & - & - \\
\hline 1797. & 1č 6ok & 9ok & 10ok & 9 ok & - & - & - \\
\hline 1798. & 3č 3ok & 5ok & 9ok & 5ok & - & - & $\begin{array}{ll}- & -1 \\
\end{array}$ \\
\hline 1799. & $6 \check{c}$ & 8 ok & 1č 3ok & - & - & - & - \\
\hline 1800. & 1č 4ok & - & 9ok & - & - & - & - \\
\hline 1801. & 3č 9ok & - & $5 o k$ & $\begin{array}{ll}- & -1 \\
-1\end{array}$ & - & - & $\begin{array}{ll}- & -1 \\
\end{array}$ \\
\hline 1802. & 0,5 č & - & - & - & - & - & - \\
\hline 1803. & - & - & lok & - & - & - & - \\
\hline 1804. & $3 c ̌ 5 o k$ & - & 8ok & - & - & - & - \\
\hline 1805. & $4 \check{c}$ & - & $12 \mathrm{ok}$ & - & - & - & - \\
\hline 1806. & - & - & 8ok & lok & - & - & - \\
\hline 1807. & - & - & - & - & - & - & - \\
\hline 1808. & - & - & 8 ok & - & - & - & - \\
\hline 1809. & - & - & - & - & - & - & - \\
\hline 1810. & - & - & - & - & - & - & - \\
\hline
\end{tabular}




\begin{tabular}{|c|c|c|c|c|c|c|c|c|c|c|c|c|c|c|c|c|}
\hline & 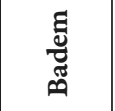 & & & & & & & & & & & & & & 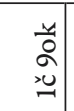 & \\
\hline & 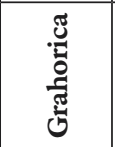 & & 吾 & & $\ddot{x}$ & & & & & & & & & & & \\
\hline & 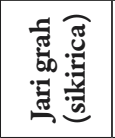 & & & & & & & & $\simeq$ & & & & $\frac{n}{b}$ & & & \\
\hline & 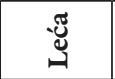 & & & & $\stackrel{\Delta}{c}$ & & & & & & & & & & & \\
\hline & $\begin{array}{l}\text { 范 } \\
\text { 总 } \\
\end{array}$ & & & & & & & & & & & & & & & \\
\hline & 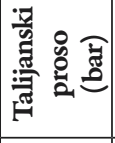 & & & & $x$ & & & & & & & & & & & \\
\hline & 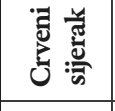 & 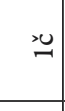 & & & & & & & & & & & & & & \\
\hline & 童 & 嫼 & 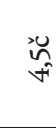 & $\stackrel{\sim}{m}$ & 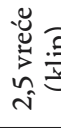 & & & & & & & 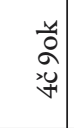 & & & & \\
\hline & 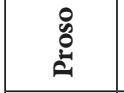 & $\stackrel{\sim}{\sim}$ & 婇 & & $\ddot{x}$ & & $:$ & & & & 茎 & & & $\approx$ & & \\
\hline & 羿 & $\simeq$ & $\stackrel{\sim}{3}$ & $\stackrel{\sim}{\sim}$ & 过 & & | & & 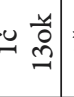 & 品 & 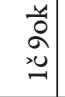 & 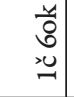 & & & $\stackrel{4}{\circ}$ & $\because \stackrel{4}{0}$ \\
\hline & 煎㤩 & $=$ & 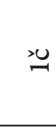 & 幽 & $\check{y}$ & & | & $;$ & 总 & $\stackrel{\sim}{n}$ & & 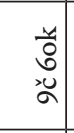 & 哈 & $\underline{m}$ & & \\
\hline & $\stackrel{\circ}{\circ}$ & 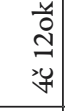 & 总 & 只 & $\ddot{n}$ & & 总 & $\because$ & & 亲 & 总 & & & & & \\
\hline & 䔍总 & 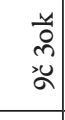 & $=$ & 总 & ry & & 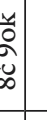 & 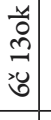 & 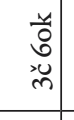 & 总 & 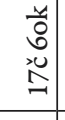 & 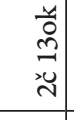 & $\begin{array}{l}\text { 离 } \\
\grave{0} \\
\infty \\
\infty\end{array}$ & 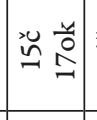 & 声 & 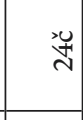 \\
\hline & త్ & $\stackrel{3}{\rightarrow}$ & & 产 & & & : & 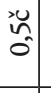 & ì & 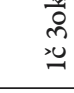 & $\ddot{c}$ & $\stackrel{x}{-1}$ & & & 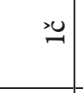 & 音 \\
\hline & 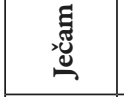 & ṿ̛ & 㣢 & י্ণ & 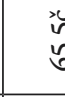 & 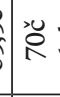 & & 文 & 党 & 冷 & $\stackrel{\infty}{=}$ & 讨 & 范 & 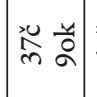 & 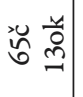 & 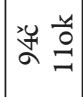 \\
\hline & ت्ठ் & $\stackrel{\infty}{\stackrel{\infty}{\prime}}$ & $\stackrel{\text { Dే }}{\stackrel{0}{\beth}}$ & $\stackrel{\infty}{\stackrel{\infty}{\infty}}$ & İ & 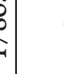 & $\stackrel{\infty}{\infty}$ & 亦 & $\stackrel{\substack{0 \\
\hdashline}}{=}$ & 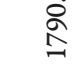 & $\vec{\beth}$ & ปิ & ఏొڤ & 索 & ปી & 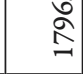 \\
\hline
\end{tabular}


Zdenko Dundović: Gospodarske prilike Zmajevićeva glagoljaškog sjemeništa u Zadru...

\begin{tabular}{|c|c|c|c|c|c|c|c|c|c|c|c|c|c|c|}
\hline 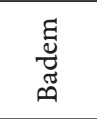 & & & & & & & & & & & & & & \\
\hline 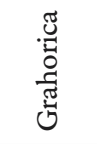 & & & & & & & & & & & & & & \\
\hline 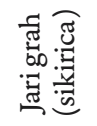 & & & & & & & & & & & & & & \\
\hline ్ֶّ & & & & & $\stackrel{y}{0}$ & & & & & & & & & \\
\hline 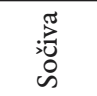 & & & & & & & & & & & & & & \\
\hline 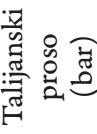 & & & & & & & & & & & & & & \\
\hline 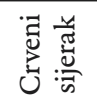 & & & & & & & & & & & & & & \\
\hline 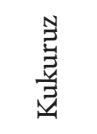 & 䒫总 & & 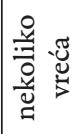 & $\ddot{n}$ & 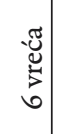 & & & & & & 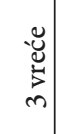 & & & \\
\hline $\begin{array}{l}\circ \\
\stackrel{0}{0} \\
\stackrel{0}{a}\end{array}$ & nun & $\stackrel{2}{=} \stackrel{4}{0}$ & 䒘 & & & & & & vu & & & $\stackrel{4}{\circ}$ & & \\
\hline $\begin{array}{l}\text { N } \\
\widetilde{\pi} \\
\simeq\end{array}$ & $\frac{4}{8}$ & 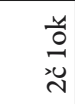 & & & & & & & & & & & & \\
\hline 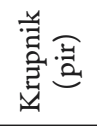 & 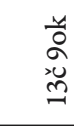 & $\stackrel{\sim}{ٍ}$ & 庵 & 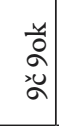 & בu & 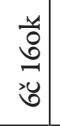 & & $\begin{array}{l}\vec{y} \\
\stackrel{0}{0} \\
z \\
\tilde{c}\end{array}$ & 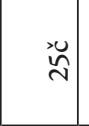 & in & $\underline{m}$ & 诗 & & \\
\hline ๑ & 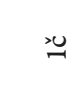 & & & $\frac{4}{2}$ & 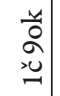 & 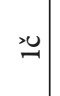 & & & & $\stackrel{4}{0}$ & & & & \\
\hline 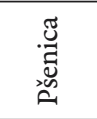 & 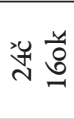 & 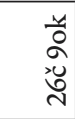 & $\ddot{ָ}$ & 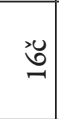 & 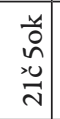 & 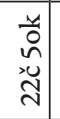 & 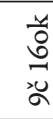 & 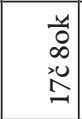 & 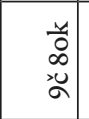 & $\underset{0}{0}$ & 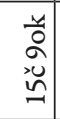 & 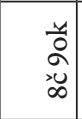 & & 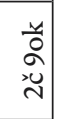 \\
\hline 窇 & 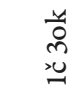 & & u & $\begin{array}{l}\ddot{4} \\
0 \\
\infty\end{array}$ & $\begin{array}{l}\stackrel{4}{0} \\
\mathbb{a}\end{array}$ & & & 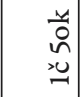 & vu & $\therefore$ & & $\frac{4}{b}$ & & $\begin{array}{l}\vec{y} \\
\text { aे } \\
\text { ỹ }\end{array}$ \\
\hline 窇 & $\begin{array}{l}u \\
\infty \\
\sigma\end{array}$ & $\begin{array}{l}u \\
n \\
n\end{array}$ & 袋 & 菢 & $\begin{array}{l}30 \\
\infty \\
n\end{array}$ & $\vec{\sim}$ & ల్లు & 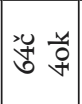 & $\begin{array}{lll}3 \\
& \stackrel{4}{0} \\
\end{array}$ & 瓷 & $\underset{f}{3}$ & $\mid$\begin{tabular}{cc}
$u$ & 4 \\
\hdashline & $\vdots$ \\
$\vdots$
\end{tabular} & & $\stackrel{u}{\sim}$ \\
\hline 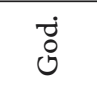 & શิ & $\begin{array}{l}\dot{\infty} \\
\stackrel{1}{=}\end{array}$ & શ் & $\begin{array}{l}\dot{8} \\
\text { D. } \\
-\end{array}$ & $\begin{array}{r}\dot{0} \\
\dot{0} \\
\end{array}$ & $\begin{array}{l}\dot{0} \\
0 \\
\infty \\
0\end{array}$ & 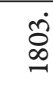 & $\begin{array}{l}+{ }^{+} \\
0 \\
-\end{array}$ & 官 & $\begin{array}{l}0 \\
0 \\
0 \\
0\end{array}$ & $\begin{array}{l}0 \\
\dot{0} \\
0 \\
-\end{array}$ & $\begin{array}{l}0 \\
0 \\
\infty \\
\rightarrow\end{array}$ & $\begin{array}{c}\dot{0} \\
0 \\
0 \\
-\end{array}$ & $\begin{array}{l}\dot{0} \\
\infty \\
-\end{array}$ \\
\hline
\end{tabular}




\section{O tečaju novca}

Rektor Calvi uredno je zapisivao svaku promjenu tečaja i vrijednosti novca u razdoblju od 1782. do 1810 . godine. Uvidom u te upise može se preciznije odrediti odnos vrijednosti dalmatinske (moneta corrente) prema mletačkoj liri i austrijskom fiorinu koji su tada bili u opticaju u Dalmaciji. ${ }^{159}$ Podatci uglavnom korespondiraju $s$ rezultatima istraživanja drugih historiografa. ${ }^{160} \mathrm{Od}$ 1782. pa sve do 1801. godine taj odnos izgledao je ovako: 1 zlatni mletački cekin $=60$ dalmatinskih lira; 1 dalmatinski cekin $=48$ dalmatinskih lira; 1 mletački talir $=$ 24 dalmatinske lire; 1 austrijski talir (Talari Imperiali $)=22$ dalmatinske lire; 1 mletačka lira $=1$ dalmatinska lira i 4 solda; 1 dalmatinska lira 20 soldi.

Calvi je 1801. godine zapisao da su najmitelji sjemenišnih posjeda zbog nestašice mletačkih zlatnih cekina u prošlim godinama plaćali najam srebrnim novcem (Monete d'Argento), uz napomenu da se tečaj cekina u tom slučaju umanjivao za 6 lira (con l'Ajo per ciascun Zecchino di 6 lire, con che rissultava il Zecchino a 54 lire). ${ }^{161}$

Nakon uspostave uprave u Dalmaciji austrijska vlast stabilizirala je tečaj tržišnog novca (moneta plateali). U uporabu je ušao i austrijski fiorin čija se vrijednost, prema Calvijevim zapisima, od 1802. do 1806. godine mjerila kako slijedi: 1 austrijski fiorin $=5$ mletačkih lira; 1 austrijski fiorin $=12$ dalmatinskih lira; 1 austrijski fiorin $=60$ karantana; 1 patakon $(\text { Pattaconi di Rame })^{162}=1$ dalmatinsku liru i 4 solda; 1 karantan $=4$ solda; 1 mletačka lira (Monette bianche marcate Lire Venete $)=4$ dalmatinske lire i 16 soldi; srebrna peturina - petica $($ Pettorine $)=8,5$ karantana; 1 srebrna peturina - petica $($ Baili $)=7$ karantana.

$\mathrm{Za}$ francuske uprave u Dalmaciji dva se puta umanjivala vrijednost novca. Dana 27. svibnja 1806. godine francuska uprava proglasila je novi tečaj. ${ }^{163}$

159 Usp. Š. PERIČIĆ, Gospodarske prilike Dalmacije, 141 - 142.

160 Usp. Š. PERIČIć, Razvitak gospodarstva Zadra, 280.

161 Liber II, 138.

162 Stari austrijski novac. Vidi više kod: Etymologisches Wörterbuch des Dolomitenladinischen, ur. Johannes Kramer, Hamburg, 1993., 203.

163 Liber III, 24. 
TABLICA 9. Usporedba tečaja novca za vrijeme austrijske i francuske uprave u Dalmaciji prema zapisima rektora Calvija iz 1806. godine

\begin{tabular}{|l|l|l|}
\hline \multicolumn{1}{|c|}{ Vrsta novca } & \multicolumn{1}{|c|}{$\begin{array}{c}\text { Tečaj za austrijske } \\
\text { uprave }\end{array}$} & \multicolumn{1}{c|}{$\begin{array}{c}\text { Tečaj za francuske } \\
\text { uprave }\end{array}$} \\
\hline $\begin{array}{l}\text { Patakun } \\
\text { (Pattaconi di Rame) }\end{array}$ & 1 lira i 4 solda & 12 soldi \\
\hline Karantan & 4 solda & 2 solda \\
\hline $\begin{array}{l}\text { Srebrna mletačka lira } \\
\text { (Monete bianche marcate lire } \\
\text { venete) }\end{array}$ & 4 lire i 16 soldi & 2 lire i 8 soldi \\
\hline $\begin{array}{l}\text { Srebrni novac pettorine } \\
\text { (Monete bianche) }\end{array}$ & 8.5 karantana & $\begin{array}{l}8 \text { karantana } \\
\text { (16 dalm. gazzeta) }\end{array}$ \\
\hline Srebrni novac baili & 7 karantana & $\begin{array}{l}6,5 \text { karantana } \\
\text { (13 dalm. gazzeta) }\end{array}$ \\
\hline
\end{tabular}

Dana 17. studenoga 1806. godine francuska vlast ponovo je izdala javni proglas o smanjenju vrijednosti novca. Došlo je do promjene vrijednosti srebrnog novca zvanog Pettorine u vrijednosti 8 karantana (16 dalmatinskih gazetta) i Baili u vrijednosti od 6.5 karantana (13 dalm. gazetta). Pettorine su bile učvršćene na 12 mletačkih soldi, a Baili na 10 mletačkih soldi. Taj se novac rabio za kupovinu hrane i namirnica, a gazetta se tada mjerila 1 mletačkim soldom. Tada je vrijednost peturine od 8 karantana umanjena na 14.5 gazzeta, a onih od 6.5 karantana na 12 gazzeta te se za francuske uprave ustalio tečaj kako slijedi: 1 fiorin $=5$ mletačkih lira; 1 mletačka lira = 20 soldi; 1 mletačka lira $=2$ dalmatinske lire i 4 solda.

Calvi je od tada prihode i rashode sjemeništa upisivao u mletačkoj moneti u odnosu 5 mletačkih lira po fiorinu i 20 soldi po liri. ${ }^{164}$ Česte promjene tržišne vrijednosti novca stvarale su poteškoću pri najmu sjemenišnih terena, a zbog promjene tečaja pala je vrijednost platežnog novca za četvrtinu što je utjecalo i na obračun plaća sjemenišnom osoblju. ${ }^{165} \mathrm{Uz}$ to, francuska je vojska pred konac francuske uprave 1813. godine u Zadru oduzela građanima i crkvenim ustanovama srebrninu od koje se kovao srebrni novac. ${ }^{166}$

164 Liber III, 33.

165 Liber III, 31-33.

166 Bože Mimica, Francuska uprava u Dalmaciji (1805.-1809.) i ilirske pokrajine (1809.-1813.) s posebnim osvrtom na uporabu novca, Hrvati i ilirske pokrajine, Zbornik radova s medunarodnoga znanstvenog skupa HAZU prigodom dvjestote obljetnice proglašenja ilirskih pokrajina (ZagrebZadar, 1.-3. listopada 2009.), ur. Franjo Šanjek, Zagreb, 2010., 531. 


\section{ŽIVOT GLAGOLJAŠKOG SJEMENIŠTA U ZADRU OD 1782. DO 1810. GODINE}

Neke informacije o životu Zmajevićeva sjemeništa u drugoj polovici 18. stoljeća ostavio je zadarski nadbiskup Ivan Carsana. U dopisu zadarskom knezu Jerolimu Bragadinu 1. srpnja 1792. godine Carsana je kronološkim redom naveo papinske bule i mletačke dekrete o ustanovi glagoljaškog sjemeništa u Zadru; zatim nadarbine i prihode za uzdržavanje sjemeništa te podatak da je tada $u$ sjemeništu bilo osam đaka uz rektora, učitelja, ekonoma i poslužitelja. Rektora je odabirao zadarski nadbiskup, a bio je dužan jednom godišnje podnijeti izviješće o upravljanju sjemeništem. ${ }^{167}$ Nadbiskup ili njegov ovlaštenik redovito su godišnje pregledavali knjige prihoda i rashoda o čemu svjedoče potpisi i odobrenja $u$ administrativnim knjigama rektora Calvija.

Zadarski nadbiskup Ivan Carsana imenovao je kanonika Josipa Calvija rektorom glagoljaškog sjemeništa 14 . ožujka 1782 . godine ${ }^{168}$ prema odredbama Tridentskog sabora u Dekretu o sjemeništima u kojemu stoji da vrhovni autoritet sjemeništa pripada biskupu, uz pomoć dvojice kanonika. ${ }^{169}$ Službu rektora Calvi je obnašao 28 godina dok ga dekretom od 28. prosinca 1810. godine nije smijenio zadarski nadbiskup Josip Grgur Scotti (1807. - 1817.), uz odredbu da mu se iz prihoda sjemenišnih nadarbina do konca života ima isplaćivati 18 dalmatinskih cekina godišnje ( 360 malih mletačkih lira). ${ }^{170}$

Calvi je pri preuzimanju dužnosti rektora preuzeo inventar sjemeništa od dotadašnjeg ekonoma don Antuna Valdenevrea. ${ }^{171}$ Prilikom primopredaje službe nadbiskup Carsana doznačio je rektoru Calviju 82 mletačka talira (Talari Veneti; 1 mletački talir nosio je 24 dalmatinske lire) i 80 austrijskih talira (Talari Imperiali; 1 carski talir nosio je 22 dalmatinske lire), što je činilo sumu od 3728 dalmatinskih lira. ${ }^{172}$ Sjemenišni novac i administrativne knjige Calvi je čuvao pod ključem u blagajni koju je dao sam izraditi u studenome 1782. godine. ${ }^{173}$

167 HR-AZDN-16/1, Zadarska nadbiskupija/Metropolija, Registrum litterarum, Dopisivanje zadarskih nadbiskupa: Carsana, 1790. - 1800., knj. 1.

168 Liber $I, 1$.

169 Nikola ŠKalabrin, Biskupijsko sjemenište u Đakovu - od osnutka do 1918., Diacovensia: teološki prilozi, 14 (2), 2006., 228.

170 Liber III, 82.

171 Liber I, 1. U knjigama se navodi i prezime ekonoma Ivana Brižića koji je tu službu obnašao prije Antuna Valdenevrea. Liber I, 30. Bianchi ga pogrešno donosi kao Giovannija Valdenevea. Usp. C. F. BIANCHI, Zara Cristiana I, 271. Antun Valdenevre, sin pok. Kristofora, u to je vrijeme bio i upravitelj nadbiskupske menze. Usp. HR-DAZD-31, Bilježnici Zadra, Giovanni Grisogono de Franceschi, 1768. - 1824., b. III, svež. 15, fol. 1r.; b. III, svež. 16, fol. 82r-v.

172 Liber $I, 1$.

173 Liber I, 13. 
Na raspolaganju pitomcima za vrijeme Calvijeva upravljanja glagoljaškim sjemeništem u Zadru bili su: rektor, ekonom, učitelj, kuhar, jedan poslužitelj, a stanovali su u sjemeništu zajedno s pitomcima. Ispovjednik pitomaca dolazio je iz samostana sv. Frane. U svojstvu ispovjednika pitomaca glagoljaškog sjemeništa za Calvijeva upravljanja spominje se izrijekom samo fra Ivan Krstitelj Passio OFM koji je ujedno početkom 19. stoljeća bio i gvardijan franjevačkog samostana sv. Frane u Zadru. Za svoju službu nije primao nikakve novčane nagrade, ali mu je u znak zahvalnosti rektor Calvi davao nešto kave i šećera. ${ }^{174}$

Uz Calvija je nadbiskup Carsana imenovao i novog ekonoma don Ivana Štrkalja (Stercagl), podrijetlom iz Drniša. Uz službu ekonoma don Ivan Štrkalj bio je u to vrijeme i sakupljač crkvene desetine na kopnu (terraferma). ${ }^{175}$ Službu ekonoma obnašao je do 1. listopada 1795. godine kada je na njegovo mjesto nadbiskup imenovao don Petra Marelića koji je na tom mjestu ostao do konca Calvijeva upravljanja glagoljaškim sjemeništem u Zadru. ${ }^{176} \mathrm{U}$ slučaju opravdane odsutnosti nadbiskup bi imenovao privremenog ekonoma koji je primao plaću razmjerno danima zamjene. ${ }^{177}$ Godišnja plaća ekonoma iznosila je 300 lira, a rektora 18 cekina, odnosno 864 lire. ${ }^{178} \mathrm{Uz}$ redovitu godišnju naknadu za svoju službu ekonom je imao pravo o trošku sjemeništa na jedan par cipela za obilazak nadarbina i redovite ekonomske poslove pri žetvi, berbi i meljavi maslina na otocima i terrafermi. ${ }^{179} \mathrm{U}$ siječnju 1799 . godine zatražili su rektor, ekonom i učitelj od zadarskog nadbiskupa povećanje godišnje plaće, što je konačno i odobreno te je ona tada iznosila za rektora 24 cekina, odnosno 1152 lire dalmatinske monete, a za ekonoma 12 cekina, odnosno 576 lira. ${ }^{180}$

Uspostavom austrijske uprave u Dalmaciji od 1802. godine plaće sjemenišnih službenika upisivao je Calvi u fiorinima, ali se njihov iznos u dalmatinskih lirama nije mijenjao. ${ }^{181}$ Dolaskom francuske uprave u Dalmaciju i promjenom tečaja Calvi je upisivao iznos plaća u mletačkim lirama, a one su tada iznosile

174 Liber II, 164.

175 Liber I, 63.

176 Liber II, 61.

177 Primjerice, 28. travnja 1789. godine ekonom don Ivan Štrkalj otišao je nadbiskupovim dopuštenjem u Veneciju (per la Dominante e l'altre parti) pa ga je u službi ekonoma zamijenio don Vinko Pasini. Isti ga je mijenjao i 1792. godine. Liber I, 83; Liber II, 6.

178 Liber I, 65.

179 Liber II, 61.

180 Liber II, 103.

181 Primjerice, Calvijeva plaća iznosila je 96 fiorina što je ekvivalentno 1152 dalmatinskim lirama. Liber II, 145. 
za rektora 96 fiorina, odnosno 480 mletačkih lira, a za ekonoma 240 mletačkih lira. ${ }^{182}$ Ekonom je stanovao u sjemeništu, na drugom katu, u sobi koja gledala prema jugu, odnosno na vrt nadbiskupske palače, a proširena je 1790. godine na njegov zahtjev. ${ }^{183}$

U ulozi učitelja klerika na platnoj listi sjemeništa u razmatranom razdoblju navode se sljedeći svećenici: don Frane Senjanović (1782. - 1786., 1791. - 1800., 1801. - 1803., ${ }^{184}$ a 1805. - 1810. u svojstvu učitelja kao kanonik ${ }^{185}$ ), don Dominik Šola (1786. - 1787.), ${ }^{186}$ kanonik Ivan Jurović (1787. - 1790.), ${ }^{187}$ don Petar Beda Salamoni (1800.), ${ }^{188}$ don Tripun Rončević (1803. - 1804.), ${ }^{189}$ don Jerolim Alesani (1804. - 1805.), ${ }^{190}$ fra Vinko Vidović OFM s Korčule (1773. - 1797.) ${ }^{191}$ i fra Andrija Kačić OFM iz Makarske (1797. - 1810.). ${ }^{192}$ U vrijeme odsutnosti fra Andrije Kačića od 1. svibnja 1807. do 17. veljače 1808. godine zamijenio ga je fra Konstantin Božić193 iz Pašmana koji je stanovao u samostanu sv. Frane za vrijeme gvardijana fra Bernardina Crljenka. ${ }^{194}$ Nakon što se u svibnju 1813. godine zbog zdravstvenih tegoba Kačić povukao iz učiteljske službe, zamijenio ga je lektor teologije fra Bonaventura iz Korčule. ${ }^{195}$ Važno je naglasiti da se u administrativnim knjigama razlikuju dvije učiteljske službe: ona učitelja klerika u zadarskoj katedrali za koju je naknada iznosila 60 lira godišnje (Senjanović, Šola, Jurović, Salamoni, Rončević, Alesani) i ona učitelja u sjemeništu, koji je tu i stanovao (fra Vidović i fra Kačić), a godišnja mu je plaća iznosila 12 cekina (576

182 Liber III, 35.

183 Liber I, 90.

184 Liber I, 6.

185 Liber III, 18; Liber III, 32; 57.

186 Liber I, 63.

187 Liber I, 76; Liber II, 1.

188 Liber II, 130.

189 Liber II, 173.

190 Liber III, 4.

191 Bio je učitelj glazbe, definitor i lektor teologije u glagoljaškom sjemeništu 24 godine. Umro je 31. srpnja 1797. godine, a troškove njegova pogreba pokrilo je sjemenište. Liber I, 92; Liber II, 83. Imao je brata dominikanca Dimitrija Vidovića koji je bio prior dominikanskog samostana u Šibeniku. Liber I, 39.

192 Liber II, 86. Fra Andrija Kačić bio je lektor teologije u Bresciji, a u glagoljaško sjemenište u Zadru došao je na zamolbu nadbiskupa Carsane. HR-AZDN-16/1, Zadarska nadbiskupija/Metropolija, Registrum litterarum, Dopisivanje zadarskih nadbiskupa: Carsana, 1790. - 1800., knj. 1., 26. travnja 1798. godine.

193 O učenom franjevcu s Pašmana, fra Konstantinu Božiću (1774. - 1860.) vidi više u: Hrvatski biografski leksikon, posjećeno 22. 1. 2017. http://hbl.lzmk.hr/clanak.aspx?id=2629

194 Liber III, 35; 46.

195 HR-AZDN-16/1, Zadarska nadbiskupija/Metropolija, Registrum litterarum, Dopisivanje zadarskih nadbiskupa: Scotti, 1812.-1814., knj. 1., br. 38 i 39. 
lira) kroz dvije semestralne isplate od 288 lira do 1799. godine, ${ }^{196}$ a 18 cekina (864 lire, 432 lire semestralno) od 1799. godine. ${ }^{197}$ Uz redovitu godišnju plaću učitelj u sjemeništu imao je pravo na novčanu naknadu i popudbinu u hrani i piću prigodom kakvih službenih putovanja, primjerice u Veneciju, ${ }^{198}$ ili redovitog godišnjeg odmora razmjerno danima odsutnosti što je redovito odobravao zadarski nadbiskup. ${ }^{199}$ Uz to je sjemenište je plaćalo i medicinsku skrb učiteljima, a česti su zapisi o bolestima, liječničkim intervencijama i lijekovima koji su se kupovali u zadarskim ljekarnama pa se iz Calvijevih zapisa saznaje ponešto i o troškovima u zdravstvu koncem 18. i početkom 19. stoljeća. ${ }^{200}$

Slavko Kovačić u svom radu o katedralnim školama u Dalmaciji pod mletačkom upravom problematizirao je, između ostaloga, zadarsku katedralnu školu, Florijevo i Zmajevićevo sjemenište. ${ }^{201}$ Tragom Minuccijeva izvješća ad limina od 1601. godine kako u „cijeloj pokrajini nema ni sjemeništa ni gramatičke škole“, ustvrdio je Slavko Kovačić da se „zacijelo katedralna škola u Zadru ipak držala“. ${ }^{202}$ Ta tvrdnja odgovara istini. Katedralna škola opstojala je pod ingerencijom zadarskog kaptola. Naime, 1601. godine zadarski arhiprezbiter Ivan Milašić (Milasseo), ${ }^{203}$ učitelj u kleričkom sjemeništu u Zadru (Maestro al pñte del Seminario di Chierici di Zara), ustanovio je za sebe i buduće nasljednike u ulozi učitelja klerika beneficij na temelju emfiteutskog zakupa in perpetuo. ${ }^{204}$ Izraz sjemenište mora se odnositi na katedralnu kaptolsku školu, $s$ obzirom na to da sjemeništa u pravom smislu riječi u Zadru tada, a i kasnije nema. ${ }^{205} \mathrm{Na}$ tu je nakanu odobrenjem Svete Stolice dano u zakup zemljište u dva dijela veličine oko 10 gonjaja $^{206}$ u vlasništvu crkve (kapele) sv. Luke u mjestu

196 Liber II, 102.

197 Liber II, 103.

198 Liber II, 108. Kada je fra Vinko Vidović išao na službeni put u Veneciju, sjemenište mu je dalo živo janje, liker (Rosoglio di Maraschino), dvije salame (due salami da tagliar), sir, govedinu, rižu, kruh i vino. Usp. Liber I, 45.

199 Fra Andrija Kačić je tako za godišnji odmor u rodnoj Makarskoj 4. kolovoza 1798. godine dobio 4 cekina (192 lire) te ribu, meso, pršut, dva kokota, masline, kruh, vino i ulje. Usp. Liber II, 98.

200 Usp. Liber I, 92.

201 Slavko Kovačić, Katedralne škole u Dalmaciji pod mletačkom vlašću od konca 16. do početka 19. stoljeća prema biskupskim izvještajima Svetoj Stolici, Croatica Christiana periodica, br. 15 (27), Zagreb, 1991., $67-71$.

202 S. KovAČıć, Katedralne škole u Dalmaciji, 67 - 68.

203 Usp. A. M. Strgačı́́, Hrvatski jezik i glagoljica, 408.

204 HR-AZDN-18, Prvostolni kaptol u Zadru, Knjiga povlastica Kaptola stolne crkve Sv. Stošije (Liber Privilegiorum Venerabilis Capituli ecclesiae cathedralis S. Anastasiae, martyris), 1399. - 1818., fol. 290.

205 Usp. S. Kovačıć, Katedralne škole u Dalmaciji, 69.

206 Od 16. stoljeća zadarski gonjaj ili gonjal iznosio je točno $2.363 \mathrm{~m}^{2}$. Marija ZANINović-RuMORA, Stare mjere za površinu u sjevernoj Dalmaciji, Radovi Zavoda za povijesne znanosti HAZU u Zadru, br. 35, Zadar, 1993., 127. 
Ždrelac na otoku Pašmanu. ${ }^{207}$ Zemljište je zakupila Marija Roza, žena Zvane Mistacchiellija, za iznos od 8 dukata i 6 lira godišnje koji se „u ime zakupa imaju isplatiti učitelju klerika svake godine na svetkovinu Božića zajedno s redovitom desetinom žita i mošta“. ${ }^{208} \mathrm{U}$ radu se dalje navodi da je nadbiskup Carsana u izvješću što ga je poslao u Rim 1777. godine zapisao u posebnom odlomku „da je odabrao «dva svećenika dobra i učena» koji «katedralne klerike napajaju disciplinama koje priliče crkvenom službeniku»" te kako nije jasno je li uz školu otvorenu u Florijevu sjemeništu paralelno djelovala i druga stara katedralna škola sve do konca 18. stoljeća. ${ }^{209}$

Možda nam zapisi rektora Calvija mogu pomoći u rješavanju te problematike. Naime, Kovačić navodi da su za učitelja katedralne škole plaću osiguravali „od dijela svojih prihoda nadbiskup, katedrala i samostan sv. Krševana“. ${ }^{210}$ Kako je glagoljaško sjemenište u Zadru bilo sljednik nadarbine samostana sv. Krševana, ono je preuzelo i sve obveze proizišle iz te nadarbine. Tu spadaju već spomenute česte obnove crkve sv. Krševana, ali i obveza pokrivanja dijela plaće učitelju u katedralnoj školi. ${ }^{211}$ Tomu u prilog ide činjenica da je godišnja plaća učitelja u glagoljaškom sjemeništu bila gotovo deset puta veća od one katedralnog učitelja za isti posao pa se vjerojatno radi o dijelu pune godišnje plaće. Nadalje, 1787. godine isplatilo je glagoljaško sjemenište 60 lira kanoniku Ivanu Juroviću za službu katedralnog učitelja. U Calvijevu zapisu od 15. svibnja 1785. godine, prigodom prodaje vina Florijevu sjemeništu, stoji da je kanonik Jurović u to vrijeme rektor Florijeva sjemeništa, ${ }^{212}$ što je i ostao do njegova zatvaranja 1797 . godine. ${ }^{213} \mathrm{U}$ zapisu od 3. travnja 1788. godine glagoljaško sjemenište plaća kanoniku Juroviću - maestro delli Chierici di questa Metropolitana per l'Oneranza dovuta per tal Offizio nell'anno scorso 1787 - iznos od 60 lira. ${ }^{214}$ A ko se plaća učiteljima Florijeva

207 Bianchi navodi da je to zemljište ostavio 1600. godine Simone Mansionario uz obvezu jedne mise u spomen pokojnika i školovanje jednog siromašnog dječaka koji bi htio postati klerik. C. F. Bianchi, Kršćanski Zadar, 399.

208 Ugovor je sklopljen 6. veljače 1601. godine u kući Zvane Mistacchiellija, a ovjerio ga je prisegnuti zadarski notar Šimun Venier. HR-AZDN-18, Prvostolni kaptol u Zadru, fol. 290-292.

209 S. Kovačić, Katedralne škole u Dalmaciji, 70 - 71.

210 S. Kovačıć, Katedralne škole u Dalmaciji, 68; 69.

211 Potvrdu tomu vidi u popisu obveza nadarbine samostana sv. Krševana gdje izrijekom stoji: Onorario al Maestro de Chierici - l(ire) 60. HR-DAZD-336, Benediktinski samostan Sv. Krševana, kut. 5., svež. 1.5.7., fol. 87r (dva su folija u svežnju označena brojem 87).

212 Liber I, 44.

213 C. F. Bianchi, Zara Cristiana I, 266; Slavko Kovačıć, Licej u Nadbiskupskom sjemeništu u Splitu i njegov teološki studij sa sveučilišnim pravima priznatim od francuske države godine 1810., Dalmacija za francuske uprave (1806. - 1813.), Zbornik radova, ur. Marko Trogrlić i Josip Vrandečić, Split, 2011., 412.

214 Liber I, 76. 
sjemeništa davala iz sredstava Florijeve zaklade, kako navodi i sam Kovačić, ${ }^{215}$ nije presmiono zaključiti da se katedralnog učitelja plaćalo iz fonda glagoljaškog sjemeništa zbog obveza proizišlih iz nadarbine samostana sv. Krševana, što bi onda ukazivalo na postojanje stare katedralne škole u Zadru. Tim više što se uplate katedralnom učitelju bilježe u Calvijevim administrativnim knjigama i nakon prestanka rada Florijeva sjemeništa, sve do 1805 . godine. ${ }^{216}$

Godine 1806. na platnoj listi glagoljaškog sjemeništa bilježi se u službi prefekta u glagoljaškom sjemeništu don Bartul Tolić iz Biograda. ${ }^{217}$ Službu je započeo u travnju 1805. godine te mu se 26. 3. 1806. isplatila godišnja plaća od 6 cekina, odnosno 288 lira dalmatinske monete. ${ }^{218}$

Bitan čimbenik svakodnevice glagoljaškog sjemeništa bio je i sjemenišni kuhar. Plaća sjemenišnog kuhara 1784 . godine iznosila je 24 lire mjesečno. ${ }^{219}$ Od 1. srpnja 1796. godine plaća kuhara je iznosila 30 lira, ${ }^{220}$ od 1800. godine 36 lira, ${ }^{221}$ a od 1807. godine 43 lire i 4 solda. ${ }^{222}$ Kuhar je, kao i poslužitelj, živio u sjemeništu te mu je ono pokrivalo troškove liječenja u slučaju bolesti. ${ }^{223}$ Ako je kuhar sudjelovao kod poslova u sjemenišnoj konobi nakon berbe, za taj posao bio je dodatno plaćen. ${ }^{224}$ Službu su napuštali svojevoljno, isključivo radi bolje plaćenog radnog mjesta, ili u slučaju bolesti, ili bi im sjemenište dalo otkaz zbog samovolje u poslu, kao što je bio slučaj s Mihom Franićem, ${ }^{225}$ ili zbog psovke na pitomce, u slučaju Ante Karlovića. ${ }^{226}$ Razvidno je iz knjiga prihoda i rashoda da je kuhinja dobro opremljena i uredno održavana, nekoliko puta obnavljan je veliki kamin koji je 1787. godine proširen, ${ }^{227}$ kao i kompletna kuhinja, ${ }^{228}$ kupljen je novi

215 S. Kovačić, Katedralne škole u Dalmaciji, 71.

216 Usp. S. KovačIć, Licej u Nadbiskupskom sjemeništu u Splitu, 412.

217 Tolić, Bartul (Bare), rođen u Biogradu. Zaređen za svećenika 17. XII. 1796. (Coll. ordinum). Godine 1795. kumuje kao žakan, a od 1807. do 1809. krštava. Član je Bratovštine Uznesenja u Biogradu. Bi brat poś(tova)ni go(spodi)n don Bare Tolić da sviću (BU Biograd, fol. 6r). 1797. na 21 agusta munta loj don Bare Tolić, li. 1 so. 10 (BU Biograd, fol. 50r). Na 20 agusta 1810 u Biogradu (munta) četvrt mesa pečena don Bare Tolić, li. 9:1 (BU Biograd, fol. 60r). Kapelan je Ugljana od 1798. do 1801. (MK Ugljan). Župnik je u Zemuniku. Umro 1. veljače 1811. God. 1. II. don Bari Tolić 1811. (KG Biograd). Pavao Kero, Leksikon svećenika glagoljaša, (u izradi).

218 Liber III, 21.

219 Liber I, 37.

220 Liber II, 72.

221 Liber II, 118.

222 Liber III, 32.

223 Dana 22. srpnja 1787. godine razbolio se kuhar Ante Marinović pa je sjemenišste platilo zadarskom kirurgu Josipu Alesaniju za puštanje krvi i liječničku skrb 12 lira. Liber I, 69.

224 Liber II, 49.

225 Liber $I, 3$.

226 Liber I, 58.

227 Liber I, 65. 
kuhinjski stol, ${ }^{229}$ a blagovaonica je imala dva stola, jedan za kojim je blagovalo vodstvo glagoljaškog sjemeništa (seconda tavola), s raskošnijim priborom za jelo, i drugi za kojim su blagovali pitomci (prima tavola).

Sjemenišni poslužitelj pomagao je u kuhinji i blagovaonici, kao i kod svakodnevnih poslova održavanja prostora ili drugih poslova. Za svoju službu primao je do 1796. godine godišnju plaću 18 lira mjesečno, od 1796. godine 24 lire, a od 1807. godine 28 lira i 12 soldi dalmatinske monete, odnosno 15 lira mletačke monete. ${ }^{230} \mathrm{Uz}$ to je sjemenište skrbilo o odjeći (braghe, coparan e gesserma) i obući poslužitelja, ${ }^{231}$ kao i kuhara. ${ }^{232} \mathrm{Za}$ Calvijeva upravljanja glagoljaškim sjemeništem u Zadru spominju se u službi poslužitelja do 1790 . godine Antonio Piovezana, ${ }^{233}$ do 1803. godine Petar Meneghetti te Petar Bettio od 1803. do 1810. godine, sin kuhara Gašpara, čija je plaća 1803. godine iznosila 1 liru dnevno. ${ }^{234}$ I žena Gašpara Bettija pomagala je u poslovima. ${ }^{235}$ U Calvijevim knjigama navode se kao uomo di servizio, servitù, sottocuoco ${ }^{236}$ ili uomo di cucina. ${ }^{237}$ Redovita naknada kuharu i poslužitelju uvećavala se jednom godišnje u visini njihove mjesečne plaće (mancia; buonaman). ${ }^{238} \mathrm{Za}$ nabavu živežnih namirnica brinuo se ekonom kojemu je rektor mjesečno izdavao određeni iznos u tu svrhu, a taj je za Calvijeva upravljanja prosječno iznosio oko 350 dalmatinskih lira, ovisno o vrijednosti monete. ${ }^{239}$

Prehrana je bila raznovrsna i pratila je uobičajene trendove građana Zadra u razmatranom razdoblju. ${ }^{240}$ Temeljila se na konzumaciji obrađenih žitarica, grahorica, krumpira i tjestenine (minestra di pasta), ${ }^{241}$ rjeđe mesa, ${ }^{242}$ a češće ribe. ${ }^{243} \mathrm{Za}$ pripremu mesa i tjestenine koristio se veliki bakreni lonac (bronzino

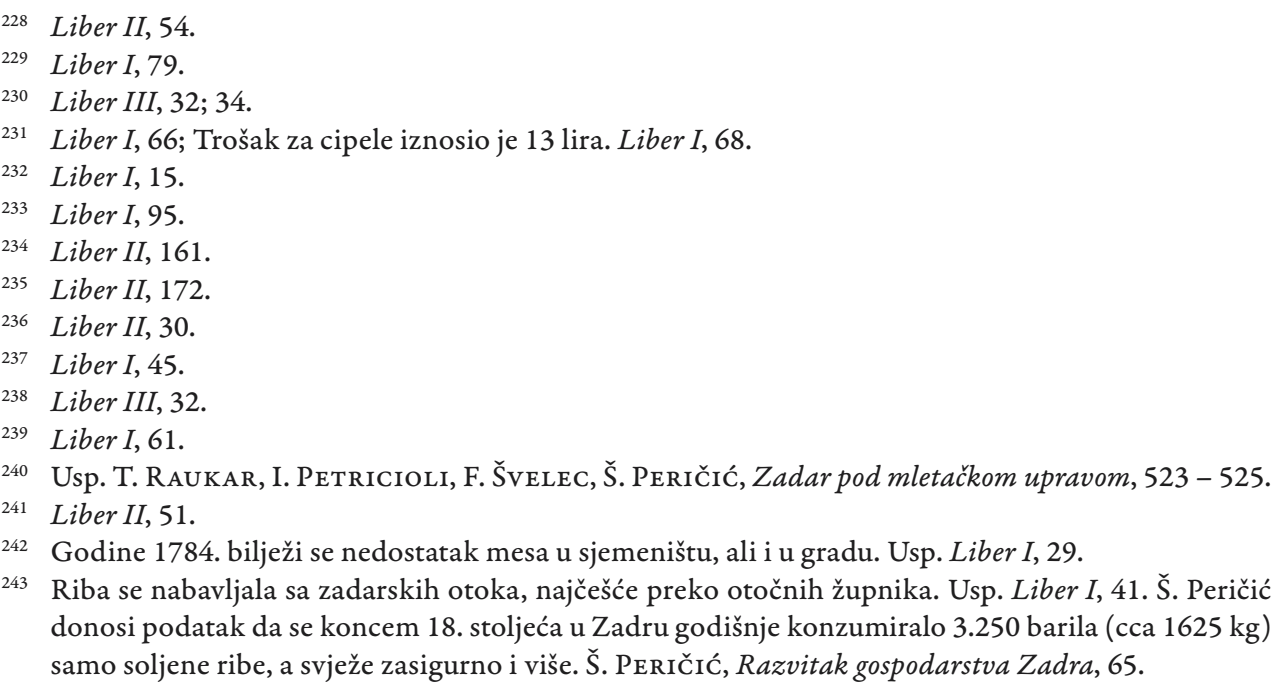
donosi podatak da se koncem 18. stoljeća u Zadru godišnje konzumiralo 3.250 barila (cca $1625 \mathrm{~kg}$ ) samo soljene ribe, a svježe zasigurno i više. Š. PERIčıć, Razvitak gospodarstva Zadra, 65. 
grande) od 8 kvartuča. ${ }^{244}$ Određene kulture i proizvodi uvozili su se uglavnom s Apeninskog poluotoka, primjerice venecijanska riža ${ }^{245}$ i leća, ${ }^{246}$ tjestenina i leća iz Puglie (bigoloni di Puglia), ${ }^{247}$ tjestenina iz Ancone (bigoli Anconitani), ${ }^{248}$ Genove (bigoloni di Genua) ${ }^{249}$ i Napulja (bigoloni di Napoli provisti in Ancona), ${ }^{250}$ kesteni, ${ }^{251}$ mahunarke i grašak, ${ }^{252}$ ali i smokve $s$ Hvara i bademi redovito $u$ korizmeno vrijeme ${ }^{253}$ te krupni grah iz Like. ${ }^{254} \mathrm{U}$ vrijeme poklada za drugim stolom (seconda tavola) jeo se usoljeni goveđi jezik ${ }^{255}$ i služio se liker, ${ }^{256}$ a tijekom cijele korizme za doručak se servirala rajčica. ${ }^{257}$ Proizvodi s Apeninskog poluotoka prevozili su se brodovima iz Venecije, a za sjemenište je u Calvijevo vrijeme taj posao obavljao najčešće parun Ante Bujačić sa Silbe, ${ }^{258}$ čiji je sin Božo bio pitomac sjemeništa. ${ }^{259}$ Zamjetno je iz administrativnih knjiga da je sjemenište redovito poslovalo s trgovcima i zanatlijama čiji su sinovi bili klerici. Nerijetko se kupovao bijeli luk s Paga po cijeni od 2 lire po restu, crveni luk te maslac, papar i sol kod zadarskih trgovaca. ${ }^{260}$ Sa sjemenišnih nadarbina pristizalo je neznatno voća, uglavnom dinje i lubenice te ponešto bundeva, a rjeđe se u računskim knjigama spominje kupovina agruma, primjerice limuna. ${ }^{261}$ Cijena mesa u to vrijeme iznosila je 2 lire po libri, a od 1806. godine 2 lire i 8 soldi po libri, ${ }^{262}$ a najčešće se konzumirala ovčetina i govedina (carne di manzo), a od mesnih prerađevina pršut i salame. ${ }^{263} \mathrm{U}$ nedostatku kruha pribjegavalo se kupovini pšenice s raznih strana o čemu se uredno bilježilo koliko je pšenice, od

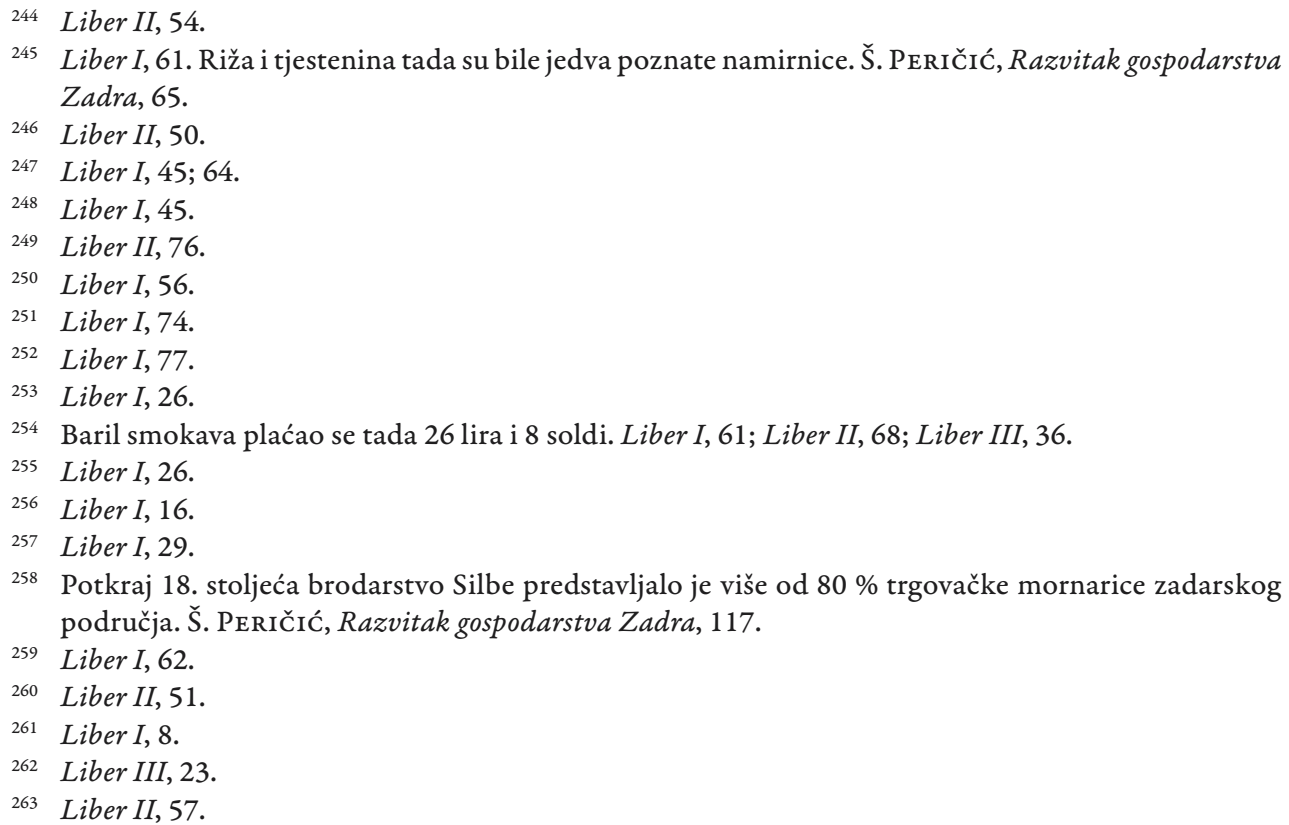


koga i po kojoj cijeni otkupljeno. ${ }^{264}$ Kupovala se i pšenica iz crkvene desetine od biskupske ili kaptolske menze. ${ }^{265}$ Nerijetko se u godinama slabog uroda pšenice i pomanjkanja kruha ona kupovala u gradskoj žitnici (Fontego) ${ }^{266}$ za pripremu dvopeka (pan biscotto), ${ }^{267}$ a kod pomanjkanja brašna kruh se kupovao kod zadarskih pekara Jakova Lombardija, ${ }^{268}$ njegova posinka Pasquala Montagne ${ }^{269}$ i Katarine Soprano, majke svećenika Franje Soprana. ${ }^{270}$ Cijena jednog kruha težine 1 četvrtalja tada je iznosila 3 lire i 4 solda. ${ }^{271}$ Često se konzumirao sir što je na ime najma i dominikala pristizao sa sjemenišnih nadarbina, a bio je iznimne kakvoće. ${ }^{272}$ Sir se čuvao u salamuri prema zadarskom receptu (formaglio di salamora alla Zaratina), ${ }^{273}$ a cijena mu je iznosila 1 liru i 4 solda po unci. ${ }^{274}$ Pravio se i slatki sir koji se čuvao u ulju (formaglio dolce in Oglio). ${ }^{275} \mathrm{Od}$ ribljih proizvoda konzumirala se usoljena tunjevina, ${ }^{276} \mathrm{o}$ korizmi suhi bakalar i nesoljena riba ${ }^{277}$ te srdela. ${ }^{278}$ Osim za posnih dana, u sjemeništu se bakalar pripremao i radnicima u vrijeme žetve, berbe i meljave maslina. ${ }^{279}$ Riba se pripremala u bakrenom kotliću (bastardella di rame per pesce) koji je za potrebe sjemeništa izradio Ivan Miletić (papusser). ${ }^{280} \mathrm{Na}$ dan sv. Krševana mogli su pitomci uživati 2 kvartuča (quartuzzi $d u e)$ prošeka (vin prossecco), ${ }^{281}$ a redovito se za sjemenišne potrebe rabilo zdravo i cijelo vino za članove uprave sjemeništa i učitelja, a vino miješano $s$ vodom (bevanda) za đake i kuhara, ${ }^{282}$ osim u oskudici ili godini slabe berbe kada su svi pili bevandu. ${ }^{283}$ Prošek se konzumirao i prigodom svečanih promocija pitomaca

264

265

266 Usp. T. Raukar, I. Petricioli, F. Švelec, Š. Peričić, Zadar pod mletačkom upravom, 524.

267 Liber II, 51.

268 Liber I, 61.

269 Liber II, 14.

270 Liber III, 5. U Zadru je koncem 18. stoljeća bilo oko 29 obrtnika te struke. Usp. Š. PERIČIĆ, Razvitak gospodarstva Zadra, 96.

271 Liber I, 82.

272 Liber II, 90.

273 Liber I, 37.

274 Liber I, 78.

275 Liber I, 48.

276 Liber I, 39.

277 Liber I, 91.

278 Liber I, 79.

279 Liber II, 84. Bakalar je u Dalmaciji bio vrlo tražena posna hrana. Fani Celio CegA, Crtice o ribarstvu i prehrani ribom u Trogiru od 18. do početka 20. stoljeća, Ethnologica Dalmatica, br. 1., Split, 2015., 138.

280 Liber I, 72.

281 Liber I, 39.

282 Liber I, 36.

283 Liber II, 139. 
u svećenički red ${ }^{284}$ te o većim crkvenim svetkovinama. ${ }^{285} \mathrm{O}$ Božiću, Uskrsu i većim svetkovinama kupovao se badem, med, ${ }^{286}$ kalabreške suhe grožđice (uva calabria) i šafran ${ }^{287}$ za pripremu božićnog kolača (bossolai di Natale) ${ }^{288}$ i uskrsne pogače (pogazza di Pasqua). ${ }^{289}$

Veliki problem svakodnevnom životu glagoljaškog sjemeništa predstavljala je pitka voda. Bunar za vodu u koji se slijevala kišnica (acqua di cisterna) nalazio se u sjemenišnom dvorištu, ${ }^{290}$ ali su slab protok i gubljenje velikih količina vode nerijetko uzrokovali pomanjkanje pa se sjemenište koristilo vodom iz cisterne obližnje pravoslavne crkve sv. Ilije (delli Greci). ${ }^{291}$ Unatoč čestim čišćenjima i zahvatima na kanalicama i samoj cisterni, od 1788. godine rektor Calvi nije uspijevao riješiti problem gubitka vode i odvoda u sjemenišnu cisternu. ${ }^{292} \mathrm{~K}$ tomu, u kolovozu 1808. godine zbog stalne suše došlo je do izrazitog manjka vode u Zadru te je sjemenište kupovalo vodu po cijeni od 1 lire po maštelu (mastello). ${ }^{293}$ Voda se kupovala s raznih strana, primjerice od mještana zadarskog predgrađa Borgo Erizzo (danas Arbanasi), ${ }^{294}$ a često su je dovozili i mornari s galija. ${ }^{295}$

TABlica 10. Primjer sjemenišnog jelovnika u korizmi 1782. godine (15. 3.-31. 3. 1782.) s troškovnikom

\begin{tabular}{|l|l|l|l|l|l|l|l|l|l|}
\hline $\begin{array}{l}\text { Kvalitet- } \\
\text { na riba }\end{array}$ & Manule & Sipa & Bakalar & $\begin{array}{l}\text { Slane } \\
\text { srdele }\end{array}$ & $\begin{array}{l}\text { Zelje } \\
\text { (erbette) }\end{array}$ & Fažol & Riža & Grašak & Rajčica \\
\hline $\begin{array}{l}37 \text { lira i } \\
16 \text { soldi }\end{array}$ & $\begin{array}{l}31 \text { liru i } \\
12 \text { soldi }\end{array}$ & $\begin{array}{l}5 \text { lira i } \\
16 \text { soldi }\end{array}$ & $\begin{array}{l}\text { 15 lira i } \\
14 \text { soldi }\end{array}$ & $\begin{array}{l}\text { 2 lire i } \\
12 \text { soldi }\end{array}$ & $\begin{array}{l}\text { 4lire i } 10 \\
\text { soldi }\end{array}$ & $\begin{array}{l}5 \text { lira i } \\
13 \text { soldi }\end{array}$ & $\begin{array}{l}\text { 8 lira i } \\
18 \text { soldi }\end{array}$ & $\begin{array}{l}\text { 4 lire i } \\
\text { 8 soldi }\end{array}$ & $\begin{array}{l}\text { 3 lire } \mathrm{i} \\
6 \text { soldi }\end{array}$ \\
\hline
\end{tabular}

284 Liber I, 27.

285 Liber I, 15.

${ }^{286}$ Liber I, 95; Liber II, 12. Male količine meda i voska (cerese) prikupljale su se sa sjemenišnih nadarbina što korespondira s razvojem pčelarstva u 18. stoljeću. Usp. Š. Peričić, Razvitak gospodarstva Zadra, $83-84$.

287 Liber II, 46.

288 Sličan se kolač pripremao i u drugim dalmatinskim gradovima. Usp. Fani Celio Cega, Kuhinja, blagovanje, prehrana u plemićkoj palači u 18. st. - ideja za novi stalni postav u Muzeju grada Trogira, Etnološka istraživanja, br. 12/13, Zagreb, 2008., 289.

289 Liber II, 82.

290 Liber I, 62.

291 Liber I, 94.

292 Liber II, 60.

293 Kupljeno je tada 27 maštela vode. Liber III, 54. Jedan maštel držao je 92,518 litara. Josip Kolanović, Šibenski metrološki sustav u XV. stoljeću, Arbivski vjesnik, br. 37, Zagreb, 1994., 198.

294 Liber III, 64.

295 Liber II, 137. Za opskrbu brodova vodom 1546. godine uređeno je vrelo u predjelu Kolovara, a 1790. godine ondje je izgrađen gat za pristajanje brodova u tu svrhu. Š. PERIČIĆ, Razvitak gospodarstva Zadra, 120. 
TABLICA 11. Popis kuhara u glagoljaškom sjemeništu u Zadru od 1782. do 1810. godine

\begin{tabular}{|l|c|c|}
\hline \multicolumn{1}{|c|}{ Ime i prezime } & Podrijetlo & Razdoblje službovanja \\
\hline Miho Franić & Kukljica & 1782. \\
\hline Toma Šarin & Ždrelac & $1782 .-1784$. \\
\hline Ante Karlović & Ugljan & $1784 .-1786$. \\
\hline Ante Marinović & Ždrelac & $1786 .-1788$. \\
\hline Josip Kromić & Mrljane & $1788 .-1791$. \\
\hline Ivan (Jovo) Marković & - & $1791 .-1795$. \\
\hline Massimo Canvelle & - & $1795 .-1800$. \\
\hline Gašpar Bettio & - & $1800 .-1810$. \\
\hline
\end{tabular}

Za potrebe kuhinje i ogrjeva sjemenište je rabilo relativno velike količine drva. Drvo se nabavljalo s raznih strana. Prvenstveno je pristizalo s nadarbina na Dugom otoku gdje je sjemenište posjedovalo šume u Brbinju, ${ }^{296} \check{Z ̌ m a n u}^{297} \mathrm{i}$ Telašćici, ${ }^{298}$ ali se i kupovalo na otocima ili od Morlaka iz zadarskog zaleđa ovisno o okolnostima. ${ }^{299}$ Cijena drva varirala je ovisno o ponudi i potražnji, a ponekad je bila prekomjerna, primjerice 1792. godine. ${ }^{300}$ Drvo iz sjemenišne šume na Gračini (Bosco Gracina) pokraj Žmana prodavalo se po 3 lire za 1 paš (passo). ${ }^{301}$ O nabavci i prijevozu drva za dnevne potrebe kuhinje brigu je vodio kuhar, a o kakvim se količinama radi zorno pokazuje podatak da je sjemenište u razdoblju od 1. rujna 1805. do konca lipnja 1806. godine utrošilo 1599 lira i 8 soldi za 4 velike barke (562 lire i 10 soldi) i 264 zaprežna kola drva (1036 lira i 18 soldi). ${ }^{302}$

\section{KARITATIVNI KARAKTER GLAGOLJAŠKOG SJEMENIŠTA U ZADRU KONCEM 18. I POČETKOM 19. STOLJEĆA}

U knjigama prihoda i rashoda rektora Josipa Calvija zapaža se izrazito karitativno djelovanje glagoljaškog sjemeništa u Zadru koncem 18. i početkom 19. stoljeća prema odredbama ustanovljenja glagoljaškog sjemeništa. ${ }^{303}$ Valja

296

Liber II, 59

298 Liber II, 55.

299 Liber I, 44.

300 Liber II, 16.

301 Liber II, 73.

302 Liber III, 26.

303 HR-AZDN-16/1, Zadarska nadbiskupija/Metropolija, Registrum litterarum, Dopisivanje zadarskih nadbiskupa: Carsana, 1774.-1790., knj. 1, 29. travnja 1785. godine. 
naglasiti da redovita pomoć siromasima nije izostajala ni za najvećih oskudica. Primjerice, 1782. i 1783. godine, prema Calvijevim zapisima, u Zadru i njegovoj okolici vladala je ekstremna glad. ${ }^{304}$ Stoga je zadarski nadbiskup naložio Calviju da se iz sjemenišnih zaliha siromasima podijeli brašna za kruh. ${ }^{305}$ Ponekad se siromasima dijelilo i vino slabije kvalitete iz sjemenišne konobe. ${ }^{306}$

Redovita godišnja pomoć siromasima u visini od 48 lira dijelila se na glavnim sjemenišnim vratima tri puta godišnje: za Dušni dan, ${ }^{307}$ na Veliku Subotu ${ }^{308}$ i na Badnjak, ${ }^{309} \mathrm{o}$ čemu je brigu vodio sam rektor. U slučaju iznimne potrebe rektor je odobravao veći iznos pomoći, kao primjerice na Veliki petak 1803. godine kada je u Zadru zabilježen veliki priliv siromaha ne samo iz grada nego i iz drugih mjesta pa im se tada podijelilo 72 dalmatinske lire. ${ }^{310}$ Međutim, u razdoblju od 1782. do 1810. godine Calvi je podijelio dodatnih 458 lira raznim siromašnim i brojnim obiteljima (per oggetto di carità), redovnicima za otkup roblja na osmanlijskom teritoriju ${ }^{311}$ ili zatočenih redovnika, ${ }^{312}$ zadarskim kapucinima za siromašne ${ }^{313}$ te za plaćanje troškova prijevoza prema Veneciji ${ }^{314}$ ili dalmatinskim gradovima najčešće samohranim majkama s djecom. ${ }^{315}$ Osobito se učestala pomoć siromašnim zadarskim obiteljima bilježi 1799. godine. ${ }^{316} \mathrm{Uz}$ to, Calvi je 1803. godine pomogao siromašnim kolonima iz Brbinja, Šimunu Mirkovu i Mati Meštrovu, za koje se zauzeo njihov župnik podijelivši ima svakome 24 lire za kupnju ječma za sijanje. ${ }^{317}$ Calvi je pomagao i opljačkane strance u Zadru, ali i francuskog časnika s Kalabrije koji je zalutao od svoje pukovnije. ${ }^{318}$ Sveukupno je od sjemenišnih prihoda za Calvijeva upravljanja siromasima podijeljeno 4583 lira i 10 soldi. No, od samoga iznosa važnija je činjenica da su sjemenišna vrata

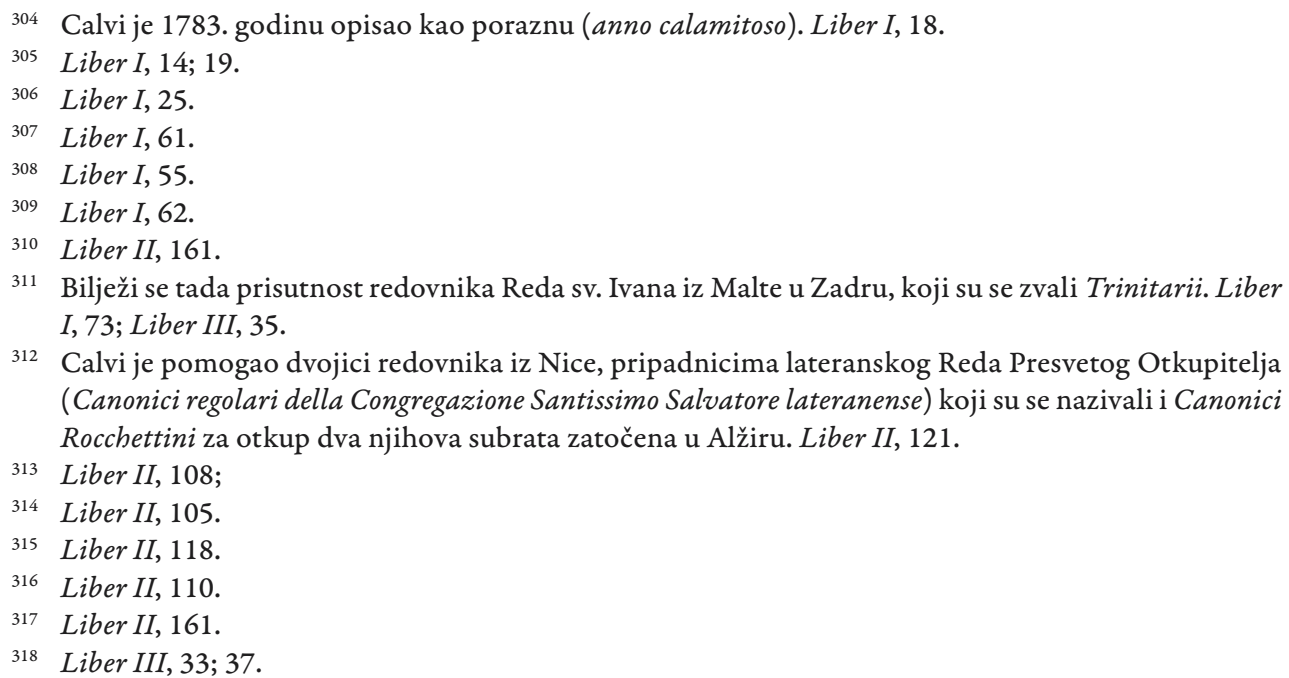


pružala utjehu i pomoć najsiromašnijim slojevima društva u Zadru koncem 18. i početkom 19 stoljeća, a osobito u teškim vremenima, što je bilo uobičajeno i za druge crkvene institucije u gradu u tom razdoblju. ${ }^{319}$

\section{PITOMCI GLAGOLJAŠKOG SJEMENIŠTA ZA CALVIJEVA UPRAVLJANJA}

Iz knjiga prihoda i rashoda rektora Calvija saznaju se šturi podatci o broju, imenima i podrijetlu pitomaca glagoljaškog sjemeništa u Zadru, kao i o njihovu školovanju. Na početku Calvijeve službe u sjemeništu je bilo 6 đaka i jedan đakon, don Vinko Pasini. ${ }^{320}$ Godine 1783. zabilježeno je da u sjemeništu stanuje 8 daka. ${ }^{321}$ Godine 1784. bilježi se da je u sjemeništu 7 đaka. Nadbiskup Carsana zapisao je u svom izvješću od 1792. godine da je smještajni kapacitet glagoljaškog sjemeništa predviđen za 16 pitomaca, ali je naglasio da prihodi sjemenišnih nadarbina ne mogu pokriti uzdržavanje tolikog broja đaka. Te je godine u sjemeništu bilo 7 đaka i 5 konviktoraca. I u Calvijevim zapisima razlikuju se đaci (Alumno) od konviktoraca (Convitore). Đaci (Alumni) bili su stipendirani iz prihoda sjemenišnih nadarbina, a đaci konviktorci plaćali su stan i hranarinu. Dnevna hranarina za klerike konviktorce iznosila je 2 lire, a za đakone i svećenike 2 lire i 8 soldi. Od 1789. godine iznos hranarine povećan je na 2 lire i 10 soldi, ${ }^{322}$ a 1799. godine na 3 lire i 4 solda dnevno. ${ }^{323} \mathrm{O}$ troškovima konviktoraca najčešće su skrbili rodbina ili župnici s kojima su bili u srodstvu, a rjeđe dobrotvori. Ako njihovi skrbnici nisu mogli pokriti troškove hrane u novcu, mogli su ih podmiriti u naturalnoj protuvrijednosti (ulje, vino, pšenica...). ${ }^{324} \mathrm{U}$ obračun hranarine pojedinog pitomca nije ulazilo vrijeme provedeno u berbi ili u pratnji nadbiskupa prigodom pastirskih vizitacija. ${ }^{325} \mathrm{U}$ slučaju bolesti pitomaca troškove medicinske skrbi pokrivalo je sjemenište. ${ }^{326}$ Uz te, Carsana je naveo i određen broj hrvatskih klerika koji su stanovali u

319 Usp. HR-AZDN-18, Prvostolni kaptol u Zadru, Spisi zadarskoga Kaptola, br. 155, kut. 24; HRAZDN-16/1, Zadarska nadbiskupija/Metropolija, Registrum litterarum, Dopisivanje zadarskih nadbiskupa: Generalni vikar Đurović, 1800.-1804., knj. 1., 6. ožujka 1802. godine.

320 Liber $I, 1$.

321 Liber I, 25.

322 Liber I, 86; HR-AZDN-16/1, Zadarska nadbiskupija/Metropolija, Registrum litterarum, Dopisivanje zadarskih nadbiskupa: Carsana, 1790. - 1800., knj. 1.

323 Liber II, 111.

324 Liber I, 65.

325 Liber I, 81.

326 Liber I, 7. 
privatnom aranžmanu u gradu, a pohađali su sjemenišnu školu. ${ }^{327}$ Okvirno se iz dostupnih podataka može zaključiti da je broj stipendiranih pitomaca u glagoljaškom sjemeništu od 1782. do 1809 . godine varirao između 6 i $8 .{ }^{328} \mathrm{U}$ svibnju 1809. godine zadarski nadbiskup Josip Grgur Scotti naložio je rektoru Calviju da primi dvostruki broj đaka u glagoljaško sjemenište, što je dodatno otežalo gospodarsko stanje zavoda početkom 19. stoljeća. ${ }^{329}$ Redovitom broju stalnih pitomaca zadarski bi nadbiskup ponekad pridodao i kojeg svećenika glagoljaša (sacerdote foraneo) kako bi se usavršio za župničku službu (ad esser istruto per l'esercizio di parroco), a troškove hranarine pokrivala bi mu nadbiskupija. ${ }^{330}$

O ulasku pitomaca u glagoljaško sjemenište odluku je donosio zadarski nadbiskup. ${ }^{331}$ Pitomce su nadbiskupu preporučivali uglavnom župnici, ali ponekad i neki viđeniji zadarski građani i državni dužnosnici. ${ }^{332}$ Kada bi jedan đakon napuštao sjemenište radi svećeničkog ređenja, na njegovo bi mjesto nadbiskup poslao drugoga. ${ }^{333}$ Prije svećeničkog ređenja đakoni su obavljali deseterodnevne duhovne vježbe u glagoljaškom sjemeništu. ${ }^{334}$ Promocija u sveti red svečano se obilježavala nakon završnog ispita pred zadarskim nadbiskupom. Primjerice, 15. prosinca 1794. godine zadarski nadbiskup Carsana poslao je 26 kandidata za svete redove na svečanu promociju na Rab koju je obavio trogirski biskup Ivan Petar Galzigna (1790. - 1795). Sedmorica kandidata bila su iz glagoljaškog sjemeništa u Zadru, a ostali pripadnici seoskog svećenstva (clero foraneo), a za sve njih popudbinu je osiguralo glagoljaško sjemenište u Zadru. ${ }^{335} \mathrm{Za}$ Calvijeva upravljanja glagoljaškim sjemeništem u Zadru bilježi se samo jedan pitomac koji nije bio pripravnik za svećeništvo, a to je Franjo Garbo, sin Katarine, udove Fontana, čiji je ulazak u sjemenište zagovarao zadarski trgovac Biasio Agazzi. ${ }^{336}$

327 HR-AZDN-16/1, Zadarska nadbiskupija/Metropolija, Registrum litterarum, Dopisivanje zadarskih nadbiskupa: Carsana, 1790.-1800., knj. 1.

328 Liber I, 33.

329 Liber III, 61.

330 Liber I, 26.

331 Usp. Liber I, 64.

332 Liber II, 95; 160; Primjerice, za klerika Božu Šokotu iz Ždrelca zauzeo se sam Dvorski komesar za Dalmaciju Peter Goëss (1802. - 1804.) pa ga je Calvi morao primiti unatoč činjenici da u sjemeništu nije bilo slobodnih kreveta. Liber II, 164.

333 Liber I, 92.

334 Liber III, 67.

335 Liber II, 51.

336 Liber II, 116. 
Smještaj za pitomce glagoljaškog sjemeništa bio je skroman, a sastojao se od dvije dvorane na drugom katu koje su služile kao zajednički dormitorij. Zbog trošnosti zgrade često se pristupalo obnovi dormitorija, ${ }^{337}$ a veći zahvat bilježi se 1795. godine kada je nadbiskup Carsana naložio izgradnju 8 niša unutar dormitorija radi pristojnijeg smještaja. Niše su bile odvojene zavjesama, a u svakoj se nalazio krevet, klecalo i sjedalica. Troškovi preuređenja pokriveni su novcem koji je sjemeništu dugovao kanonik Melhior Petrina iz Velog Lošinja. ${ }^{338}$ Kvalitetniji materijal za obnove i preuređenja u sjemeništu nabavljao se u Veneciji i Ankoni, a na njega se nije plaćao porez državi jer je bio za osobnu upotrebu, iako je bilo i takvih pokušaja koje je osporio zadarski knez, ${ }^{339}$ dok su vapno i pijesak pristizali sa zadarskih otoka. ${ }^{340}$

O teološkoj naobrazbi pitomaca brinuo je sjemenišni učitelj koji je stanovao zajedno s đacima, a soba mu je bila na prvom katu zgrade (camera che guarda sopra la Piazza del Duomo). ${ }^{341}$ Učiteljeva soba potpuno je obnovljena u studenome 1797. godine. ${ }^{342} \mathrm{U}$ lipnju 1802. godine preselio se učitelj fra Andrija Kačić u sobu na drugom katu. ${ }^{343} \mathrm{O}$ školskom inventaru vodila se osobita briga. ${ }^{344}$ Školske stolice i skriptoriji za đake bili su izrađeni od venecijanskog drva (albeo veneziano), ${ }^{345}$ kao i stol za učitelja. ${ }^{346}$ Tijekom školske godine pitomci su obavljali duhovne vježbe, za što je Calvi dao izraditi drveni križ ukrašen pozlaćenim ornamentima jer je duhovno napredovanje uz obrazovno bilo temeljem odgoja budućih svećenika. ${ }^{347}$ Učionica je bila najsvjetlija dvorana u sjemenišnoj zgradi s 4 prozora i nalazila se na najvišem katu. ${ }^{348}$ Poučavanje teologije odvijalo se na hrvatskom nastavnom jeziku u sažetom obliku prema priručniku moralne teologije Antuna Kačića Bogoslovje diloredno. ${ }^{349}$ Sjemenišni primjerak priručnika održavao je 1793. godine

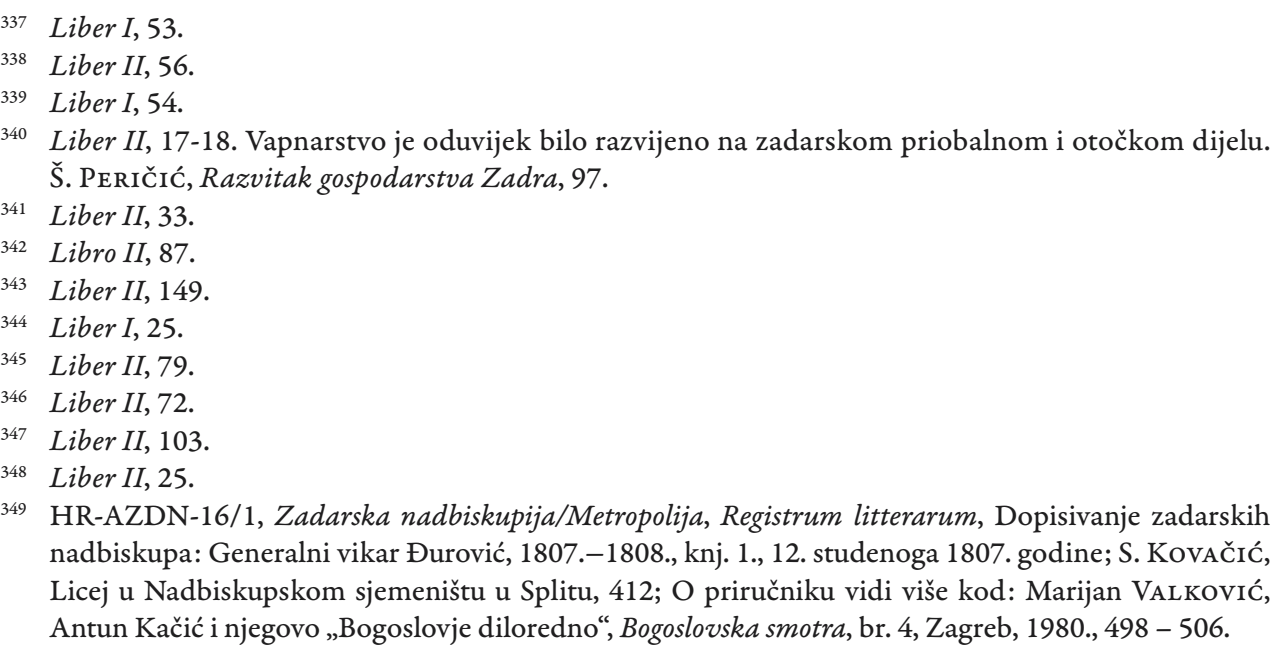


Antonio Luigi Battara, osnivač poznate zadarske tiskare. ${ }^{350}$ Tablično se prikazuju osnovni podatci o pitomcima glagoljaškog sjemeništa u Zadru od 1782. do 1810. godine prema zapisima rektora Calvija.

TABLICA 12. Pitomci glagoljaškog sjemeništa za Calvijeva upravljanja

\begin{tabular}{|c|c|c|c|c|c|}
\hline $\begin{array}{c}\text { Ime } \mathbf{i} \\
\text { prezime }\end{array}$ & Status & Podrijetlo & $\begin{array}{c}\text { Godina } \\
\text { boravka u } \\
\text { ilirskom } \\
\text { sjemeništu }\end{array}$ & Skrbnik & Podatci \\
\hline Šime Sičić & đakon & Dobropoljana & 1782. & & \\
\hline Šešelja & & Zaglav & 1782. & & \\
\hline $\begin{array}{l}\text { Mate } \\
\text { Crnović } \\
\text { (Cerneich) }\end{array}$ & đakon & Radošinovac & 1782. & & \\
\hline $\begin{array}{l}\text { Vinko } \\
\text { Pasini } \\
\end{array}$ & dakon & & 1782. & & \\
\hline Dundović & klerik & & 1783. & & $\begin{array}{l}\text { Umro u sjemeništu } \\
\text { da male Cronico }\end{array}$ \\
\hline $\begin{array}{l}\text { Ante } \\
\text { Košćica } \\
(\text { Coschizza) }\end{array}$ & dakon & Olib & 1783. & & \\
\hline \multirow[t]{2}{*}{\begin{tabular}{|l} 
Lovre \\
Petričević
\end{tabular}} & dakon & Olib & 1783. & & \\
\hline & dakon & Dragove & 1784. & & \\
\hline Rakar & đakon & & 1784. & & \\
\hline Juraj Bujačić & & Premuda & 1784. & Petar Filippi & \\
\hline Adam & dakon & Kolan & 1784. & & \\
\hline \begin{tabular}{|l|} 
Božo \\
Bujačić \\
\end{tabular} & klerik & Silba & 1785. & $\begin{array}{l}\text { otac Ante } \\
\text { Bujačić, parun }\end{array}$ & \\
\hline $\begin{array}{l}\text { Mate Stazić } \\
(\text { Stasich })\end{array}$ & đakon & Pašman & 1785. & & $\begin{array}{l}\text { Godine } 1785 . \\
\text { zaređen za } \\
\text { svećenika }\end{array}$ \\
\hline
\end{tabular}
l(ire). Liber II, 31. Antonio Battara prodao je Calviju i treću administrativnu knjigu po cijeni od 36 lira i 12 soldi. Liber III, 1. O tiskari Battara vidi više kod: Pavao GALIć, Povijest zadarskih tiskara, Zagreb, 1979., $21-26$. 


\begin{tabular}{|c|c|c|c|c|c|}
\hline $\begin{array}{c}\text { Ime i } \\
\text { prezime }\end{array}$ & Status & Podrijetlo & $\begin{array}{c}\text { Godina } \\
\text { boravka u } \\
\text { ilirskom } \\
\text { sjemeništu }\end{array}$ & Skrbnik & Podatci \\
\hline $\begin{array}{l}\text { Petar } \\
\text { Smoljan }\end{array}$ & klerik & Ist & 1785. & $\begin{array}{l}\text { otac Petar } \\
\text { Smoljan }\end{array}$ & $\begin{array}{l}\text { Došao u sjemenište } \\
\text { 9. } 10.1785 \text {. } \\
\text { Spominje se ponovo } \\
\text { 5. 5. } 1787 . \text { Kao } \\
\text { subđakon spominje } \\
\text { se } 18.12 .1788 . \\
\text { Kao đakon } 13.7 \text {. } \\
\text { 1789. Ponovno kao } \\
\text { dakon } 18.5 .1790 . \\
\end{array}$ \\
\hline Šime Blasul & klerik & Kali & 1786. & $\begin{array}{l}\text { don Božo Blasul, } \\
\text { stric i otac Šime } \\
\text { Blasul } \\
\end{array}$ & $\begin{array}{l}\text { Došao u sjemenište } \\
\text { 23. } 1.1785 \text {. }\end{array}$ \\
\hline Ive Dražić & dakon & Kali & 1787. & $\begin{array}{l}\text { don Lovre } \\
\text { Dražić, brat }\end{array}$ & $\begin{array}{l}\text { Primljen u } \\
\text { sjemenište kao } \\
\text { dakon 3.5. } 1786 .\end{array}$ \\
\hline Jure Matešić & dakon & Molat & 1787. & & \\
\hline $\begin{array}{l}\text { Jure Mikuš } \\
\text { (Michos) }\end{array}$ & & Banj & 1788. & $\begin{array}{l}\text { otac Jerolim i } \\
\text { brat Ante }\end{array}$ & \\
\hline Michel & dakon & Iž & 1788. & & \\
\hline $\begin{array}{l}\text { Dominik } \\
\text { Supičić } \\
\text { (Zupichich) }\end{array}$ & klerik & Silba & 1788. & \begin{tabular}{|l|} 
sin pok. Bartola \\
Supićiča; Antun \\
Dorkin, zadarski \\
trgovac
\end{tabular} & \\
\hline $\begin{array}{l}\text { Ante } \\
\text { Kulonja } \\
(\text { Culogna) }\end{array}$ & klerik & Nevidane & 1788. & & \\
\hline $\begin{array}{l}\text { Šime Mirko } \\
(\text { Simo } \\
\text { Mirco) }\end{array}$ & klerik & Olib & 1788. & $\begin{array}{l}\text { otac Ivan i brat } \\
\text { Martin }\end{array}$ & \\
\hline $\begin{array}{l}\text { Martin } \\
\text { Kevrić }\end{array}$ & klerik & Poličnik & 1789. & \begin{tabular}{|l} 
don Jure \\
Kevrić, župnik \\
Poličnika, stric \\
\end{tabular} & $\begin{array}{l}\text { Dana 31. 3. } 1792 . \\
\text { spominje se kao } \\
\text { dakon. }\end{array}$ \\
\hline Juraj Bujačić & klerik & Premuda & 1789. & \begin{tabular}{|l|} 
don Ante \\
Petričević, \\
župnik Premude \\
\end{tabular} & \\
\hline $\begin{array}{l}\text { Martin } \\
\text { Matulj }\end{array}$ & subđakon & Turanj & 1790. & & \\
\hline Jure Kevrić & klerik & Poličnik & 1792. & \begin{tabular}{|l|} 
don Jure \\
Kevrić, župnik \\
Poličnika, stric \\
\end{tabular} & \\
\hline
\end{tabular}




\begin{tabular}{|c|c|c|c|c|c|}
\hline $\begin{array}{c}\text { Ime i } \\
\text { prezime }\end{array}$ & Status & Podrijetlo & $\begin{array}{c}\text { Godina } \\
\text { boravka u } \\
\text { ilirskom } \\
\text { sjemeništu }\end{array}$ & Skrbnik & Podatci \\
\hline Mate Milić & klerik & Kukljica & 1793. & $\begin{array}{l}\text { don Vinko } \\
\text { Pasini }\end{array}$ & \\
\hline $\begin{array}{l}\text { Marko } \\
\text { Armanini }\end{array}$ & klerik & & 1798. & $\begin{array}{l}\text { primljen u } \\
\text { sjemenište } \\
\text { na zagovor } \\
\text { Dominika } \\
\text { Petriciolija iz } \\
\text { Sali }\end{array}$ & \\
\hline Jure Lukačić & klerik & Biograd & 1799. & $\begin{array}{l}\text { don Krševan } \\
\text { Lukačić, župnik } \\
\text { Biograda, stric }\end{array}$ & \\
\hline $\begin{array}{l}\text { Franjo } \\
\text { Gabro }\end{array}$ & laik & Zadar & 1800. & $\begin{array}{l}\text { majka Katarina, } \\
\text { udova Fontana }\end{array}$ & $\begin{array}{l}\text { Primljen na zagovor } \\
\text { Blaža Agazija. Bio } \\
\text { je laik i učenik u } \\
\text { sjemeništu. }\end{array}$ \\
\hline Jure Strgačić & subđakon & Tkon & 1800. & $\begin{array}{l}\text { don Jakov } \\
\text { Strgačić, župnik } \\
\text { Tkona, stric }\end{array}$ & \\
\hline Šime Bolić & dakon & & 1801. & & $\begin{array}{l}\text { Zaređen za } \\
\text { svećenika na Pagu. } \\
\text { Zaredio ga kotorski } \\
\text { biskup Franjo Petar } \\
\text { Rakamarić. }\end{array}$ \\
\hline Mate Pavić & dakon & & 1801. & & $\begin{array}{l}\text { Zaređen za } \\
\text { svećenika na Pagu. } \\
\text { Zaredio ga kotorski } \\
\text { biskup Franjo Petar } \\
\text { Rakamarić. } \\
\end{array}$ \\
\hline $\begin{array}{l}\text { Matija } \\
\text { Šimeta }\end{array}$ & dakon & Veli Rat & 1801. & & \\
\hline Stipčević & & Olib & 1801. & $\begin{array}{l}\text { don Ante } \\
\text { Stipčević, župnik } \\
\text { Oliba, stric }\end{array}$ & \\
\hline Božo Šokota & klerik & Ždrelac & 1803. & & $\begin{array}{l}\text { zagovor kneza De } \\
\text { Goezza }\end{array}$ \\
\hline \begin{tabular}{|l|} 
Vinko \\
Lovrović
\end{tabular} & klerik & $\begin{array}{l}\text { Zadar } \\
\text { (katedrala) }\end{array}$ & 1803. & & \\
\hline $\begin{array}{l}\text { Ivan } \\
\text { Školjarev }\end{array}$ & subđakon & & 1803. & & \\
\hline
\end{tabular}


U spisima zadarskog nadbiskupa Josipa Grgura Scottija nalazi se popis đaka glagoljaškog sjemeništa u Zadru iz 1813. godine, kandidata za svećeničko ređenje, koji su bili đaci za vrijeme Calvijeve rektorske službe, pa se ti podatci tablično prikazuju. ${ }^{351}$

TABLICA 13. Kandidati za svećeničko redenje 1813. godine, bivši pitomci glagoljaškog sjemeništa u Zadru

\begin{tabular}{|l|l|c|c|}
\hline \multicolumn{1}{|c|}{ Ime i prezime } & \multicolumn{1}{c|}{ Podrijetlo } & Starosna dob & Godine školovanja \\
\hline Mate Rudić & Tkon & 27 god. & 8 \\
\hline Špiro Duka & Arbanasi & 25 god. & 7 \\
\hline Andrija Karlić & Kukljica & 25 god. & 7 \\
\hline Šime Masar & Lukoran & 25 god. & 8 \\
\hline Martin Košćica & Kukljica & 25 god. & 8 \\
\hline Jakov Mišlov & Kali & 23 god. & 8 \\
\hline Mate Jurišić & Vrgada & 23 god. & 4 \\
\hline Petar Matulić & Molat & 23 god. & 3 \\
\hline
\end{tabular}

DRUŠTVENO-POLITIČKE I VOJNE OKOLNOSTI KONCEM 18. I POČETKOM 19. STOLJEĆA U DALMACIJI I NJIHOV UTJECAJ NA ŽIVOT GLAGOLJAŠKOG SJEMENIŠTA U ZADRU PREMA ZAPISIMA REKTORA JOSIPA CALVIJA

Vrijednost Calvijevih računskih knjiga ogleda se u činjenici da je njegovo upravljanje glagoljaškim sjemeništem u Zadru (1782. - 1810.) obuhvatilo propast Mletačke Republike, uspostavu prve austrijske i dolazak francuske uprave na vlast u Dalmaciji. Calvi je u kratkim crtama zapisivao društvenopolitičke mijene koncem 18. i početkom 19. stoljeća i njihov utjecaj na život i ekonomske prilike glagoljaškog sjemeništa u Zadru. Calvi je tako zapisao da je 12. svibnja 1797. godine abdicirala Mletačka Republika, a izrazio je pritom i svoje žaljenje (con danno innesprimibile di tutti noi Sudditi suoi fedelissimi) pa su gradske vlasti molile za pomoć uvećanju plaća vojnicima u Zadru koji su danonoćno, prema uputi generalnog providura Andree Querinija, držali stražu

351 HR-AZDN-16/1, Zadarska nadbiskupija/Metropolija, Registrum litterarum, Dopisivanje zadarskih nadbiskupa: Scotti, 1812.-1814., knj. 1, br. 42. 
kako bi spriječili pobunu što je već zahvatila druge gradove u Dalmaciji. Calvi je na tu nakanu dao 4 mletačka talira, odnosno 96 dalmatinskih lira. ${ }^{352}$ Promjenom vlasti u Dalmaciji došle su i nove nevolje za glagoljaško sjemenište. Nakon pada Mletačke Republike napadnut je sjemenišni gastald u Brbinju. ${ }^{353}$ Kako se diljem Dalmacije širila anarhija, Calvi zapisuje da je Zadar, zajedno s ostalim gradovima provincije, priznao vlast cara Franje II. te su 1. srpnja 1797. godine austrijske trupe ušle u grad. ${ }^{354}$ Vojsci i časnicima ponuđen je smještaj u zadarskim samostanima i dvama sjemeništima. ${ }^{355}$ Papa Pio VI. uputio je na zamolbu austrijskog cara breve mjesnim biskupima u Dalmaciji da se muški i ženski samostani ustupe za smještaj austrijske mornarice. U ime nadbiskupa Carsane okružnicu dalmatinskim biskupima o tom breveu poslao je kapitularni vikar Ivan Armani u siječnju 1798. godine. ${ }^{356} \mathrm{U}$ veljači 1798. godine, unatoč teškom zdravstvenom stanju zadarskog nadbiskupa, austrijske vlasti zahtijevale su iscrpno izvješće o stanju Zadarske nadbiskupije. ${ }^{357}$ Protucrkvena liberalna strujanja nadahnuta jozefinizmom očitovala su se $u$ javnom izrugivanju zadarskih klerika od strane austrijskih službenika pa je nadbiskup Carsana uputio protest austrijskim vlastima. ${ }^{358}$

U glagoljaškom sjemeništu vojska je zauzela školsku učionicu, jednu sobu, jednu prostoriju u prizemlju i sjemenišnu kuhinju za potrebe austrijskih časnika. Iako su vlasti skrbile o prehrani svojih časnika, znatan dio troškova oko njihova smještaja pao je na sjemenište. ${ }^{359}$ Ubrzo su austrijski časnici u potpunosti zaposjeli sjemenišnu kuhinju te je rektor Calvi bio primoran podići novi kamin i napu za njemačkog časnika kako bi se oslobodila kuhinja za potrebe sjemeništa. ${ }^{360} \mathrm{U}$ travnju 1798. godine austrijski kapetan otvorio je vojni ured na prvom katu sjemeništa te zauzeo dvije sobe za sebe i suprugu i poslugu, a

352 Liber II, 79; Usp. Josip Posedel, Zadar 1797-1813, Zadar Zbornik,ur. Jakša Ravlić, Zadar, 1964., $195-196$.

353 Liber II, 88.

354 Usp. Šime Peričıć, Marija Stagličıć, Antun Travirka, Zvjezdana Rados, Glorija RabacČondrić, Zadar za austrijske uprave, Zadar, 2011., 25 - 26; Carlo Federico BIANCHI, Fasti di Zara, Zadar, 1888., 117 - 118.

355 U gradu se tada smjestilo preko 2000 austrijskih vojnika. Š. PERIČIĆ, M. STAgličić, A. TRAVIRKA, Z. RADOs, G. RABAC-ČonDRIĆ, Zadar za austrijske uprave, 27.

356 HR-AZDN-16/1, Zadarska nadbiskupija/Metropolija, Registrum litterarum, Dopisivanje zadarskih nadbiskupa: Carsana, 1790. - 1800., knj. 1.

357 HR-AZDN-16/1, Zadarska nadbiskupija/Metropolija, Registrum litterarum, Dopisivanje zadarskih nadbiskupa: Carsana, 1790.-1800., knj. 1., 21. veljače 1798. godine.

358 HR-AZDN-16/1, Zadarska nadbiskupija/Metropolija, Registrum litterarum, Dopisivanje zadarskih nadbiskupa: Carsana, 1790. - 1800., knj. 1., 5. kolovoza 1798. godine.

359 Liber II, 80; 84.

360 Liber II, 91. 
preuređenje je palo na račun sjemeništa. ${ }^{361} \mathrm{U}$ nastojanju da omogući normalan život sjemenišne zajednice, a onemogući austrijske časnike da odlažu smeće na trećem katu sjemeništa, Calvi je na stepenište postavio nova željezna vrata, ${ }^{362}$ a jedan ključ dobilo je osoblje sjemeništa i jedan pitomci. ${ }^{363} \mathrm{U}$ svibnju 1798. godine austrijski pukovnik barun Riera zahtijevao je od nadbiskupa da se isprazni soba predviđena za sjemenišnog poslužitelja i ustupi njegovu časniku pa je Calvi morao uložiti dodatna sredstva za provizorno uređenje smočnice za smještaj poslužitelja. ${ }^{364}$ Austrijski časnici ostali su u sjemeništu do ožujka 1800. godine, ${ }^{365}$ a vojna oprema i nakon njih. Nakon čestih traženja nadbiskupa Carsane austrijska vojska je u studenome 1800. godine uklonila vojnu opremu iz crkve sv. Donata koja je tamo bila uskladištena od ulaska austrijskih trupa u Zadar ${ }^{366}$ te ju premjestila u potkrovlje i jednu manju prostoriju u prizemlju glagoljaškog sjemeništa. ${ }^{367}$ Iako je Vlada obećala da neće više uzurpirati sveta mjesta, to se nije ispoštovalo. Crkve su se pretvarale u skladišta za brašno, a redovnicima otežavao svakodnevni život. ${ }^{368}$ Saznaje se da je 1802. godine austrijska vojska ponovo zauzela sjemenišnu zgradu, ali i nadbiskupski dom.

Kako su u Zadar u vrijeme korizme pristizali kapucini iz Venecije održati redovite korizmene propovijedi, Calvi ih je morao primiti u sjemenište na stan $i$ hranu zbog okupacije nadbiskupskog doma, što je dodatno opteretilo sjemenišnu blagajnu. ${ }^{369} \mathrm{U}$ rujnu 1802. godine naređuje se Calviju evakuacija sobe za poslugu u sjemeništu za potrebe vojske od strane generala Marcheta, na što je Calvi uputio dvije tužbe. ${ }^{370}$

Smrću nadbiskupa Carsane 12. prosinca 1800. godine ${ }^{371}$ Calvi se suočio s novim nevoljama na osobnoj i profesionalnoj razini. Zadarski kaptol htio je smijeniti kanonika Calvija s mjesta rektora pa se on pripremio obraniti dokumentima ustanove glagoljaškog sjemeništa, ali je kaptol na koncu odustao

\footnotetext{
361 Liber II, 92; 94.

362 Liber II, 91.

363 Liber II, 93.

364 Liber II, 94.

365 Liber II, 117.

366 HR-AZDN-16/1, Zadarska nadbiskupija/Metropolija, Registrum litterarum, Dopisivanje zadarskih nadbiskupa: Carsana, 1790.-1800., knj. 1., 4. rujna 1799. godine; C. F. Bi ANCHI, Fasti di Zara, 120.

367 Liber II, 129.

368 HR-AZDN-16/1, Zadarska nadbiskupija/Metropolija, Registrum litterarum, Dopisivanje zadarskih nadbiskupa: Generalni vikar Đurović, 1800.-1804., knj. 1., 5. travnja 1802. godine.

369 Liber II, 147; 161. O kapucinima u Zadru vidi: Zdenko Dundović, Kapucinski tragovi u Zadru tijekom 18. i 19. stoljeća, Croatica Christiana periodica, br. 79, Zagreb, 2017., 1 - 20.

370 Liber II, 154.

371 Liber II, 130.
} 
od svoje nakane. ${ }^{372}$ Taj slučaj govori da je Calviju teško pala sama pomisao da napusti rektorsku službu za koju se vezao, što je zorno vidljivo i u zapisima o njegovoj smjeni 1810. godine na koncu treće administrativne knjige. ${ }^{373}$ Paralelno s nakanom zadarskog kaptola o smjeni rektora uslijedilo je imenovanje predstojnika vladinog Ureda za računovodstvo Nicolòa Veriga upraviteljem nadbiskupske menze u Zadru i glagoljaškog sjemeništa kojemu je Calvi morao predočiti sjemenišnu dokumentaciju i polagati račune. ${ }^{374} \mathrm{Od} 1802$. godine Verigo je sklapao ugovore o najmu sjemenišnih posjeda i zemljišta nadbiskupske menze pa se može govoriti o kontroli prve austrijske uprave nad crkvenim dobrima i prihodima. ${ }^{375} \mathrm{U}$ troškove sjemeništa za vrijeme prve austrijske uprave ubraja se i trošak od 29 lira i 10 soldi za osam velikih svijeća prigodom dolaska u Zadar Dvorskog komesara za Dalmaciju baruna Francesca Marie di Carneo-Steffanea 20. ožujka 1802. godine kada je naređeno da se u gradu osvijetle prozori svih zgrada, ${ }^{376}$ a jednako su zahtijevale i francuske vlasti, primjerice za Napoleonove pobjede nad Pruskom kod Jene. ${ }^{377} \mathrm{U}$ rujnu 1806. pozvao je austrijski car sve koji su oštećeni smještajem vojske za vrijeme njihove uprave da predaju zahtjev za obeštećenje. Calvi je predao zahtjev alla Municipalità Comunale priloživši autentične dokumente esaurito dal Protocolo kneza Antuna Begne i austrijskog quartier mastra prema kojemu sjemenište potražuje 376 fiorina. Zahtjev je preko prvostupanjskog suda u Zadru upućen austrijskom povjereniku koji ga je proslijedio u Beč odakle se čekalo povoljno rješenje. ${ }^{378}$ Novac za obeštećenje za vrijeme Calvijeva upravljanja glagoljaškim sjemeništem nije uplaćen u sjemenišnu blagajnu. Gotovo 60 \% prostora sjemenišne zgrade od prizemlja do potkrovlja zauzela je vojska za prve austrijske uprave u Dalmaciji, a sjemenišna je blagajna zbog stalnih obnova i premještanja trpjela gubitke, čime je život i rad

\section{Liber II, 130.}

373 Liber III, 81-85.

374 Liber II, 132; HR-AZDN-16/2, Zadarska nadbiskupija/metropolija, Spisi Zadarske nadbiskupije/ Ordinarijata, 1797.-1806., kut. 1, dokument br. 373 od 25. siječnja 1801. godine; HR-AZDN-16/1, Zadarska nadbiskupija/Metropolija, Registrum litterarum, Dopisivanje zadarskih nadbiskupa: Generalni vikar Đurović, 1800.-1804., knj. 1., fol. 2r-v.

375 Usp. Liber III, 20; 22; HR-AZDN-16/1, Zadarska nadbiskupija/Metropolija, Registrum litterarum, Dopisivanje zadarskih nadbiskupa: Generalni vikar Đurović, 1800.-1804., knj. 1., 2. travnja 1805. godine.

376 Liber II, 145. O barunu Carneo-Steffaneu vidi više kod: Vjekoslav MašTrović, Dva primjera odnosa austrijskih vlasti prema umjetninama u prvoj polovini XIX. st. u Dalmaciji i Istri, Prilozi povijesti umjetnosti u Dalmaciji, br. 21, Split, 1980., 657 - 663

377 Liber III, 30; Usp. Frano BARAs, Dalmatinski dani maršala Marmonta, Dalmacija za francuske uprave (1806.-1813.), Zbornik radova, ur. Marko Trogrlić i Josip Vrandečić, Split, 2011., 214 - 216.

378 Liber III, 29. 
u glagoljaškom sjemeništu bio znatno otežan. ${ }^{379}$ Konstantna napetost rektora Calvija rezultirala je popuštanjem discipline đaka u sjemeništu. U spisima generalnog vikara Ivana Jurovića zabilježeno je da su oni mjesecima dovodili u svoj dormitorij neku ženu iz grada na lošem glasu pa je Jurović naložio postavljanje već spomenutog prefekta Tolića za sjemenišnog odgojitelja. ${ }^{380}$

Nakon smjene vlasti u veljači 1806. godine ušle su francuske trupe u Dalmaciju, a s njima i nove poteškoće za gospodarski život sjemeništa. Francuska vojska bezobzirno se odnosila prema crkvenim prostorima u Zadru. ${ }^{381}$ Primjerice, 24. siječnja 1807. godine nadbiskupski dom u Zadru zahvatio je požar te su uništeni i pokradeni mnogi dokumenti nadbiskupijskog arhiva zbog čega je protestirao generalni vikar Jurović i tražio povrat dokumentacije, ali se francuska vlast na to oglušila. ${ }^{382}$ Francuska mornarica nasilno je zauzela skladište iznad sjemenišnog podruma u blizini lučkih vrata (Porta Marina) i izbacila najmitelja Steffana Manzinellija iz Ankone. Prema ugovoru koji je potpisao njegov udruženik Michel Schelini, morao je Calvi nadoknaditi štetu zbog prekida najma (488 lira i 12 soldi) te je u tužbi generalnom providuru Dandolu naveo da gubitkom prostora i dalje ostaju obveze ugovora (perdendo la località non perda gl'affitti). ${ }^{383}$ Zapisao je da je buka uzrokovana radovima francuske vojske u skladištu iznad vinskog podruma 1807. godine bila uzrokom pljesnivom i kiselom vinu ( 6 bačava) pa je te godine sjemenište ostalo sa samo jednom bačvom zdravog vina. ${ }^{384}$ Okupacija skladišta prouzročila je tako dvostruku materijalnu štetu glagoljaškom sjemeništu. Calvi je više puta molio generalnog providura Dandola da se oslobodi skladište, ${ }^{385}$ o čemu je ostavio opsežan zapis. ${ }^{386}$ Međutim, odgovori generalnog providura mahom su bili cinični u skladu s njegovom naravi. ${ }^{387}$ Već u rujnu 1806. godine Dandolo je

\section{Liber III, 23.}

380 HR-AZDN-16/1, Zadarska nadbiskupija/Metropolija, Registrum litterarum, Dopisivanje zadarskih nadbiskupa: Generalni vikar Đurović, 1804.-1806., knj. 1., 6. travnja 1805. godine.

381 Usp. Ante Bralić, Zadar kao administrativno i političko središte Dalmacije za francuske uprave, Dalmacija za francuske uprave (1806.-1813.), Zbornik radova, ur. Marko Trogrlić i Josip Vrandečić,

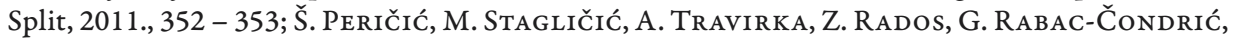
Zadar za austrijske uprave, 33.

382 HR-AZDN-16/1, Zadarska nadbiskupija/Metropolija, Registrum litterarum, Dopisivanje zadarskih nadbiskupa: Generalni vikar Đurović, 1807.-1808., knj. 1., 20. travnja 1807. godine.

383 Liber III, 26; 43.

384 Liber III, 41.

385 Liber III, 27. Doista je u knjigama protokola Generalnog providurstva Dalmacije u Zadru zavedeno Calvijevo reagiranje, ali dokument nije pronađen u svežnju na koji protokol upućuje. Vidi: HRDAZD-57, Generalno providurstvo Dalmacije u Zadru, Urudžbeni zapisnici (Protocoli), 1806.-1809., knj. 9, tit. IV, dokument br. 3522 od 21. listopada 1806.

386 Liber III, 41; 43.

387 Usp. F. BARAs, Dalmatinski dani maršala Marmonta, 209. 
tražio ukinuće nastave na hrvatskom jeziku u glagoljaškim sjemeništima u Zadru i Priku kod Omiša, a zagovarao uporabu talijanskog jezika u pouci. ${ }^{38} \mathrm{Ne}$ čudi stoga da je generalni vikar Jurović u zamolbi generalnom providuru radi podjele subđakonata kleriku Ivanu Mariji Mariniću sa Silbe naveo da on napreduje u učenju talijanskog jezika. ${ }^{389}$ Dandolo je naime morao potvrditi svako imenovanje i napredovanje klerika i svećenika, a to je činio po političkom ključu. ${ }^{390}$ Dandolo je odlučivao i o pripuštanju pitomaca u glagoljaško sjemenište. ${ }^{391}$

Uz to, generalni providur Dandolo oduzeo je u kolovozu 1806. dio novca namijenjenog sjemeništu i naredio da se pohrani u središnju blagajnu (Central Camera), čemu se Calvi usprotivio. ${ }^{392}$ Odnos generalnog providura Dandola prema rektoru Calviju i glagoljaškom sjemeništu u Zadru može se sagledati kroz njegov općenit stav i u kontekstu nepromišljenih reformi prema Crkvi u Dalmaciji koje su konačno doživjele potpuni krah. ${ }^{393}$

U rujnu 1806. godine stigla je obavijest da će se vojska povući iz sjemeništa, a đaci se vratiti svojim službama. Francuska vojska dotad je već u potpunosti uništila sjemenište koje je zahtijevalo opsežnu obnovu. ${ }^{394} \mathrm{Uz}$ to, zbog čestih gusarskih napada tijekom 1807. godine na Jadranskom moru ${ }^{395}$ kasnile su isplate najma sjemenišne nadarbine Sv. Petra na Osoru i Unijama zbog nemogućnosti plovidbe iz Velog Lošinja prema Zadru, a ekonomsko stanje sjemeništa bilo je sve teže. ${ }^{396}$

U lipnju 1808. francuska vojska iselila je iz sjemeništa $s$ drugog kata sjemeništa pa je Calvi pristupio obnovi đačkih dormitorija, što je donijelo nove

388 F. BARAs, Dalmatinski dani maršala Marmonta, 210.

389 HR-AZDN-16/1, Zadarska nadbiskupija/Metropolija, Registrum litterarum, Dopisivanje zadarskih nadbiskupa: Generalni vikar Đurović, 1807.-1808., knj. 1., 5. srpnja 1807. godine.

390 To se vidi primjerice u slučaju don Martina Pestića iz Bokanjca koji je trebao biti imenovan župnikom u mjestu Radovin. Generalni vikar Jurović u molbi je zapisao: ...egli non ha nessuna Canonica eccesione presso di me, come pur spero non ne' avrà nessuna politica presso di voi. HRAZDN-16/1, Zadarska nadbiskupija/Metropolija, Registrum litterarum, Dopisivanje zadarskih nadbiskupa: Generalni vikar Đurović, 1807.-1808., knj. 1., 11. studenoga 1807. godine.

391 Dana 12. studenoga 1807. godine pisao je generalni vikar Jurović zamolbu Dandolu da dopusti ulazak u sjemenište i pristup kleričkom staležu Marku, sinu Jurja Dundovića iz Radovina. HRAZDN-16/1, Zadarska nadbiskupija/Metropolija, Registrum litterarum, Dopisivanje zadarskih nadbiskupa: Generalni vikar Đurović, 1807.-1808., knj. 1.

392 Liber III, 28.

393 Usp. Vicko Kapitanović, Hrvatska Crkva pod francuskom vlašću, Croatica Christiana periodica, br. 33, Zagreb, 1994., 135 - 156

394 Liber III, 28.

395 Usp. Š. PERIČIĆ, Razvitak gospodarstva Zadra, 134.

396 Liber III, 36. 
troškove. ${ }^{397} \mathrm{~K}$ tomu, ubrzo je trebao doći novi zadarski nadbiskup Josip Grgur Scotti u nadbiskupski dom te se moralo urediti cisternu za vodu koju su onečistili francuski vojnici ${ }^{398}$ koji su se i inače neodgovorno ponašali prema sjemenišnoj imovini ${ }^{399}$ prema ustaljenom modusu operandi. ${ }^{400}$ Poput prve austrijske uprave, $\mathrm{i}$ francuska vlast miješala se u nadarbine na Dugom otoku pa je svojim dekretom dodijelila vinograde i maslinike u Salima Šimunu Micheliju, ${ }^{401}$ a on je kasnije tražio da mu se pripuste i zemljišta u Žmanu, što je stvaralo dodatni pritisak rektoru Calviju s obzirom na obveze sklopljenih ugovora za te posjede. ${ }^{402}$ Unatoč svim poteškoćama, Calvi je nastojao omogućiti normalan rad pitomcima glagoljaškog sjemeništa pa je 1806. godine, nakon što je francuska vojska zauzela najviši kat zgrade, preselio školu u sjemenišno potkrovlje. ${ }^{403}$

Osobito teško stanje glagoljaškog sjemeništa bilježi se 1809. godine u vrijeme austrijske opsade Zadra. ${ }^{404} \mathrm{U}$ listopadu 1808. godine francuska vojska ponovo je zauzela sjemenišne prostorije. Francuski pukovnik Petar Damiani Vergada naredio je da se zatamne prozori na prvom katu sjemeništa za potrebe francuskih trupa. ${ }^{405}$ Pitomci su poslani kućama, morske prometne puteve za prilaz sjemenišnim nadarbinama i mlinovima za meljavu pšenice bilo je nemoguće koristiti, a Calvi se prestao hraniti u sjemeništu ${ }^{406}$ u kojemu su tada bili učitelj, ekonom, posluga i don Šime Barbaroša, kojega je nadbiskup poslao u sjemenište jer nije imao gdje stanovati. ${ }^{407}$ Najmitelji su kasnili s isplatama, ${ }^{408}$ težaci su odbijali platiti dominikal, a gusari su pokrali većinu sjemenišne sitne stoke u Telašćici ${ }^{409}$ pa su rasli troškovi sudskih parnica. ${ }^{410} \mathrm{Uz}$ to, francuska uprava uvela je u opticaj obveznice (Cedole; Carte Monetatte), što je rezultiralo potpunim nedostatkom

\footnotetext{
397 Liber III, 50.

398 Liber III, 51.

399 Liber III, 23.

400 Usp. A. Bralić, Zadar kao administrativno i političko središte, 353.

401 Liber III, 57.

402 Liber III, 65.

403 Liber III, 27.

404 O opsadi Zadra 1809. godine vidi više kod: Ante Bralić, Tea EscheBACH, Austrijska opsada Zadra 1809. godine, Radovi Zavoda za povijesne znanosti HAZU u Zadru, br. 50, Zadar, 2008., 213 $-234$.

405 Liber III, 55.

406 U 28 godina rektorske službe Calvi nijednom nije večerao u sjemeništu, što je na koncu obračunao kao dug sjemeništa prema sebi u iznosu od 5030 lira i 16 soldi. Liber III, 83.

407 Liber III, 65.

408 Liber III, 66.

409 Liber III, 71.

410 Liber III, 70.
} 
efektivnog novca u sjemenišnoj blagajni. Najmitelji su plaćali rentu francuskim obveznicama koje Calvi nije uspijevao unovčiti, što je pogodovalo lihvarstvu, pa su primjerice kod kupovanja namirnica za dnevne potrebe zadarski trgovci umanjivali vrijednost tih obveznica za $22 \% !^{411}$ Međutim, to ne iznenađuje jer je i francuska intendatura u Zadru postupala na isti način kod zamjene obveznica za novac pa je sjemenište i tu bilo oštećeno. ${ }^{412}$

Dodatni ekonomski pritisak na rektora Calvija izvršio je nadbiskup Scotti u travnju 1810. godine kada je naložio da se sjemenište pobrine o prehrani nemoćnih i starih svećenika. ${ }^{413}$ Teško se dolazilo i do drva za potrebe kuhinje, a tada su ga jedino zadarski Arbanasi dovozili u grad, i to uglavnom panjeve vinove loze i veće grane maslina koje su prodavali po precijenjenih 12 dalmatinskih lira po naramku pa je sjemenište od 1. studenoga 1809. do konca srpnja 1810. utrošilo 797 mletačkih lira i 16 soldi samo za drva. ${ }^{414}$

Usporedbom odnosa prve austrijske i francuske uprave prema Crkvi i njezinim institucijama u Zadru uočava se identičan obrazac ponašanja. I jedni i drugi gledali su u Crkvi i njezinim službenicima izvanredno sredstvo promicanja vlastitih interesa u organizaciji uprave i reforme školskog sustava u Dalmaciji, istodobno ju percipirajući kao prepreku u ostvarenju vizije modernog društva utemeljenu na jozefinističkim i prosvjetiteljskim idejama. ${ }^{415}$

\section{ZAKLJUČAK}

Zalaganjem nadbiskupa Vicka Zmajevića u Zadru je podignuto glagoljaško sjemenište za pouku hrvatskih klerika na materinjem jeziku radi bolje pastoralne zauzetosti i obrane katoličke vjere na prostoru Dalmacije. U tu svrhu pripojene su nadarbine benediktinskog samostana sv. Krševana i opatije sv. Petra u Osoru glagoljaškom sjemeništu u Zadru čiji su prihodi bili izvor financiranja života i djelovanja budućih svećenika glagoljaša i njihovih odgojitelja. Sačuvani blagajnički dnevnici sjemenišnog rektora i zadarskog kanonika Josipa Calvija za razdoblje od 1782. do 1810. godine vrijedno su povijesno vrelo za promatranje prvenstveno gospodarskih prilika i neprilika glagoljaškog sjemeništa u

411 Usp. Š. PERIČIĆ, Gospodarske prilike Dalmacije, 143.

${ }^{412}$ Liber III, 69; 73.

413 Liber III, 72.

414 Liber III, 74.

415 Usp. Stjepan Ćosıć, Državna uprava u Dalmaciji i crkveni preustroj 1828./1830. godine, Croatica Christiana Periodica, 65 (2010.), 56 - 57. 
Zadru koncem 18. i početkom 19. stoljeća. Poput ostalih crkvenih ustanova, život glagoljaškog sjemeništa ovisio je o prihodima sjemenišnih nadarbina utemeljenih na kolonatskim ugovorima i trajnim zakupima. Nedovoljno razvijena poljoprivredna tehnologija, česte vremenske nepogode i društveno-političke mijene na ovim prostorima koncem 18. i početkom 19. stoljeća bitno su utjecale na gospodarsku situaciju glagoljaškog sjemeništa u Zadru. U takvim okolnostima ono je ipak opravdalo svrhu i odgojilo većinskom hrvatskom stanovništvu Zadra i njegove okolice svećenike glagoljaše koji su živjeli i poučavali puk u vjeri, dijelili s njim dobro i zlo u turobnim i tjeskobnim danima pod tuđinskim vlastima koje su se izmjenjivale na našim prostorima. 
PrIlog 1. Prijepis bule pape Benedikta XIII. od 30. prosinca 1729. godine o ustanovljenju glagoljaškog sjemeništa i pripojenju nadarbina Sv. Krševana u Zadru i Sv. Petra u Osoru (Izvor: HR-DAZD-336, Benediktinski samostan sv. Krševana, kut. 5, svež. 1.5.10., fol. 35-40)

Benedictus Episcopus Seruus Seruorum Dei Ven(erabili) Fratri Episcopo Nonensi salutem, et Apostolicam Benedictionem. Inter Sacrosanctae Tridentinae Sinodi caelitus emissas Sanctiones illa nobis potissimum est Cordi per quam apud singulas Metropolitanas, et Cathedrales Ecclesias Ecclesiastica puerorum Seminaria, veluti Militantis Ecclesiae Tentoria erigi demandatur, ut in eis Pueris bonae indolis, bonaeque voluntatis Sacris Litteris probisque moribus adolescant, adultique exeis, tamquam generosi Catuli et Latebris exilientes in uibiorum exitium, et ad Ecclesiasticae disciplinae erumpant progressum. Quapropter ad debitam tam Salubris Sanctionis Executionem praecipuam Pastoralis N(ost)ri muneris Curam dirigentes, cum adeam Vigil Praesulum praesertim quorum pusillum, et exilem sibit Comissum Gregem inimica Schismaticorum adhui crassari non desinit uersutia nos prouocat studium ad Laudabilia eorum uota adiutricem Apostolicae N(ost)rae Liberalitatis dexteram Libenti animo protendimus, secumque per ualidam Sacrarum Litterarum Scientia, Vitae ac morum honestate Clipeatorum Militum opera reduci illuc Ortodoxae Religionis tranquillitati incumbimus, et Triumphorum faecunditati omniaque desuper impartimur quae ad tuendam inter infernae noctis errorum Vmbras purum aeternae claritatis Lumen prospicimus in Domino Salubriter expedire. Cum itaque sicuti Venerabilis Frater Vincentius Zmaievich Archie(pisco)pus Jadrensis nobis nuper exposuit Prouincia olim Regnum Dalmatiae quae etsi retractis temporibus florentissimus Sacrosanctae Matris Ecclesiae ager, ex quo proceres frugiferaeque tot prodierant Apostolicorum Dogmatum plantae, ut ex earum erudita fructuum ubertate ipsa Mater Ecclesia inumerum filiorum sibi strenue militanti in Terris, et Triumphanti in Coelis alere consueuerunt Caetum nunc uero Prouincia huiusmodi magna ex parte sub infidelium Tyrannide excessus in tenebrosum nullumque admitteris Sacrarum Scientiarum cultum impietatis Nemus, et Schismaticis Orientalibus, Haereticisque Septentrionalibus praesertim Serbianis ac Turcis ipsis undique resserta in horridam uenenatarum ac faedurum Belluarum huiusmodi Fedem conuersa reperiatur propeteaque eiusdem Provinciae Clerus Illiricus ignorantiae tenebris obuolutus scientiarumque huiusmodi Cultus Illiricus ope destitutus Populum illum aeternae ueritatis semitas edocere eique Verbum Dei serere non ualeat, et pleriquae ex Populo huiusmodi Schismaticis heriticisque praedictis imixti, eorumque uenena sibi dulciter apposita incante bibentes, et perua Litis Ortodoxae Religionis Dogmatum Pharmacis sanari non ualentes aeternae Vitae Lumen deserere misere cogantur, et licet Vincentius Archie(pisco)pus praedictus alias, et a sui regiminis primordijs, ac postquam ex debito sui Pastoralis muneris Eccl(esi)am Jadrense, ac Vniuersam illius Dioecesim, Clerum et Populum, ilorumque statum perlustrauerat et Aliquantibus sibi prae Lacrymis Paterni 
sui amoris Occulis diu fleuerat super pusillo sibi Omisso Dominico Grege huiusmodi, quo ob rudem Lectorum illum ad aeterna Pascua minantium custodiam sepae sepius Infidelium et praecipue Serbianorum haereticorum praedictorum rapinis exponebatur raptusque in dies angebatur, ac per eumdem Vicentium Archie(pisco)pus comperto quod extra Ciuitatem Jadrensem et in uniuersa illius Dioecesi huisumodi septuaginta et ultra Parochiales Ecclesiae quae non nisi Clericis, seu Praesbiteris ex Clero praedicto existentibus, qui in praedictis ignorantiae tenebris, ut praedictur inuoluti sine ullo Magistratorum Librorumque commodo et non aliud nisi Illiricum Idioma calentes illa propterea carent idoneitate quae ad debitae animarum curae huisumodi munia praesertim in illis Partibus exequenda requiritur conferri non ualent, numerabantur prout numerantur de praesenti ad effugandas imposterius a Clero praedictorum exitiosas ignorantiae huiusmodi tenebras, eique exhibendus Sacrarum Litterarum Lumen proquod Populo sibi deinde Omisso pro tempore, et in umbra Mortis ambulanti tutum rectumque iter ad Caelestia Regna ostendere ualeret nonnulla publica Gymnasia in Ciuitate Jadrensis praedicta pro eiusdem Cleri Clericis inibi edocendis erudiendisque opportuno Litterarum huiusmodi clispet proprijs sumptibus menutenenda apperuerit, et aperta existant. Nihilominus dictus Vincentius Archie(pisco)pus proinde attendens quod Gymnasia ipsa futuris temporibus a Clericis extra Ciuitatem praedictam, et in illius Dioecesi huisusmodi existentibus attenta Genitorum Suorum paupertate Clericos ipsos extra eorum Domos alere non calentium non frequentutura, et a pro tempore existentibus E(pisco)pis Jadrensibus attenta Mensae Archiepiscopalis eiusdem Ecclesiae Jadrensis fructuum tenuitate dimissura sint, Clerusque praedictus non sine Spirituali Populi huiusmodi detrimento in Lacrymabile ueteris suae ignorantiae profundum sit prolapsurus et quamsuis Eccl(esi)ae Jadren(sis) iliusque Mensae Archiepiscopalis praedictarum paupertas deffectusque mediorum ad infrascripti Collegij seu Seminarij aedificationem manutentionemque procurandas opportunorum, plures Collegij seu Seminarij ut infra erigendi et instituendi huiusmodi institutionis praedictae cura a Vigili eisu mente anerterint attamen dictus Vincentius Archie(pisco)pus firma ope fidutiaque conceptis in illo quo bonae menti succurit uiresque adauget quique si dat incipere dat quoque perficere in Ciuitate Jadrensis praedicta et in loco ad id ab eodem Vincetnio Archie(pisco)po elleto eddefitia in usum Collegij seu Seminarij erigendi seu instituendi huiusmodi cum eisu Scholis Mansionibusque ac officinis pro Magistrorum et puerorum in eo tempore introducendorum et Ministrorum in eis pro tempore interuientium comodo proprijs eius sumptibus construere inceperit et prope olim adiunante Domino aedifitium huiusmodi constructione ad debitam eorum perfectionem perducturus sit, et si quemadmodum idem Vincentius Archie(pisco)pus Nobis subiunxitaedifitia praedicta quorum perfectio ut praedictur munificentia dante Domini imminet ex hunc, et cum primum illa perfecta fuerit in Collegium seu Seminarium puerorum Ecclesiasticorum Jadrensium pro certo puerorum Illiricorum Illirico idiomate dumtaxat in Ecclesiastici Ritibus utentium in eo ut infra educandorum, et instruendorum numero a Nobis ut infra perpetuo erigerentur, et instituerentur eidem 
Collegio seu Seminario ut infra erigendo et instituendo pro illius, nec non Puerorum, Praeceptorum, Offitialium aliorumque Ministrorum in eo pro tempore degentium congruis manutentione et sustentatione attento quod media pro praemissis suportandis a Concilio Tridentino Episcopis delegati, et imposita ob Ecclesiasticorum redituum in illis partibus ab infidelium auaritia depauperatorum tenuitate, et pauperiem ab Archie(pisco)po Jadrensis exerceri non ualeant unum Sancti Crysogoni Jadrensis quod Franciscus Antonius Tetta ac alterum Monasteria Abbatiae nuncupata Sancti Petri Auxerensis respectiue Ciuitatis Sancti Benedicti seu alterius respectiue Ordinis, quod Josephus Capitani Clerici, seu Praesbiteri Filij in comendam ad eorum respectiue Vitam ex ancessiore Apostolica ad uitam obtineri consueuerunt, ac cuius uidelicet secundo Dicti Monasterij Mensa Abbatialis a Mensa Conuentuali separata existit similiter ex nunc pro ut ex tunc, et e Contra cum primum illa illorum Comenda huiusmodi ex eorumdem Francisci Antonij, ac Josephi respectiue Persona quouis modo cessante uacare contigerit etiam perpetuo ut infra unirentur annectarentur et incorporarentur illorumque respectiue fructus, redditus, et prouentus eidem Collegio seu Seminario ut infra erigendo seu instituendo similiter perpetuo applicarentur, et appropriarentur aliaque infra coriederentur ex erectione, institutione, unione, anexione, incorporatione, applicatione, appropriatione alijsque infrascriptis huiusmodi probe (prate?) debiteque inibi adolescentum aetas a teneris anis ad pietatem, et Religionem, nec non spirituale illarum partium utilitatem informaretur et uiresceret. Quare pro parte dicti Vincentij Archie(pisco)pi Nobis fuit humiliter supplicatum quominus pijs Pastoralis sui muneris uotis huiusmodi in praemissis benigne anuere, et publico spirituali Gregis sibi Comissi bono opportune consulere de benignitate Apostolica dignaremur Nos igitur qui personas Ecclesiastica praesertim animarum curae incumbentes, sereno Scientiarum, ac Sanctorum morum Lumine tamquam sydera ambulantibus per huius saeculi tenebras rectas ad Caeleste patriam semitas monstrantia in Sacrosanctae Ministis Ecclesiasticae Caelo rubilare perpeti satagimus cura, praedicti Vincentij Archie(pisco)pi nota in praemissis confouere eumque specialis gratiae fauore prosequi uolentes, et a quibusuis suspensionis, et interdicti, alijsque Ecclesiasticis Sententijs Censuris, et poenis a Jure, uel ab homine quauis occasione, uel Causa Latis, si quibus quomodolibet inodatus existit ad effectus praesentium tantumodo consequendum harum serie absoluentes, et absolutum fore Censentes Supplicationibus a praedicto Vincentio Archie(pisco)po Nobis desuper humiliter porrectis benigne inclinati Fraternitati tuae attento quod Tu ut dictus Vincentius Archie(pisco)pus asserit Ordinarius uicinior illarum partium existis per Apostolica Scripta Mandamus, quatenus uocati qui fuerint euocandi, aedifitia praedicta ex nunc, et cum primum illa ut praemittitur perfecta fuerint cum omnibus, et singulis Scholis, Officinis, Oratorio, hortis, et Mandionibus in eo existentibus in Collegium, seu Seminarium puerorum Ecclesiasticorum pro certo puerorum Illiricorum Illirico idiomate in Ecclesiasticis Ritibus et functionibus utentium, et non aliroum numero a Vincentio Arcie( pisco)po praedicto praescribendo, et in eo iuxta prouidam Regularum, seu Statutorum, et Decretorum ad eodem Vincentio 
Archie(pisco)po desuper edendorum Sacris tamen Canonibus, ac Constitutionibus Apostolicis, et praedicti Concilijs Decretis minime aduersantium alendorum, ac Religiose educandorum, et Ecclesiastica disciplina instruendorum, ac quorum indoles, et uoluntas spem attulerit eos Ecclesiasticis Ministerij in idiomate praedicto perpetuo inseruituros, nec non certo etiam Magistrorum pueros ipsos educantium, ac Offitialium, aliorumque Ministrorum inibi inseruientium numero, quae educatio, et instructio praedictae exegerint, ac praedictus Vincentius Archie(pisco)pus, et pro tempore existens Archie(pisco)pus Jadrensis opprotunum fore diudicauerint et per dictum Vincentium Archie(pisco)pum ac pro tempore existenti Archie(pisco)pum Jadrensis praedictus, ita quod liceat eidem Vincentio Archie(pisco)po ac pro tempore existenti Archie(pisco)po Jadrensis praedicto dumtaxat, et non alteri unicuique Superiori, quacumque auctoritate, superioritate, et praeeminentia polletni Pueros ipsos eligere, Magistros, Offitiales, aliosque Ministros quoscumque deputare, illosque amonere, et in eorum Locum alios prout prouidum Collegij, seu Seminarij ut infra erigendi, et instituendi huiusmodi annuorum Reddituum quantitas, et temporum qualitas ad procurandam illius manutentionem seu incrementum id suaserit, et expendiens uidebitur subrogare, et substituere, numerumque ipsum augere, uel minuere, regendum gubernandum, et plenarie administrandum Apostolica auctoritate praesentium, sine tamen alicuius praeiuditio perpetuo erigas, et instituas, eoque sic erecto, et instituto, primo dictum, quod Cura Conuentuque caret, ac cuius ad Tercentum, nec non secundo dictam Monast(eri)a huiusmodi cui Cura non iminet animarum ac cuius ad Sexaginta tres Florenos auri, cum uno Tertio alterius Floreni similis respectiue fructus, redditus, et prouentus in Libris Camerae Apostolicae taxati reperiuntur ex nunc pro ut ex tunc, et e contra cum primum illa percessus etiam et Causa permutationis, uel decessus seu priuationem, aut quamuis alim demissionem, uel amissionem, seu religionis ingessus, et Professionis emissionem, et Francisci Antonij et Josephi praedictorum, aut alias quouis modo Comenda praedicta respectiue cessante uacare contigerit etiam si actu nunc quouis modo, quem etiam si ex illo quaeuis generalis resseruatio etiam in Corpore Juris clauda ressultet pro expresso haberi uolumus, aut ex aliorum quorumcumque personis, seu per liberas Francisci Antonij, et Josephi praedictorum, uel quorumuis aliorum cessiones de Monasterijs praedictis illorumque legimine, et administratione in Romana Curia uel extra eam, etiam coram Notario publico, et Testibus sponte factas, aut assecutionem alterius Benefitij Ecclesiastici Ordinaria auctoritate collati, Comenda ipsa respectiue cessante uacent, et si tanto tempore uacauerint, quod eorum collatio iuxta Lateranensis Statuta Concilij ad Sedem Apostolicam Legitime deuoluta dictaque Monasteria dispositionis Apostolicae specialiter resseruata existant, eisque cura tantum Jurisdictionalis imineat, et super eis inter aliquos Lis cuius litis Statum praesentibus haberi uolumus pro expresso pendeat in decisa et de illis Consistorial... disponi consuerit, seu debeat, ac illorum respectiue titulum collatiuum, naturam, et essentiam regularis, et denominationem Abbatis in illis ita ut deinceps in eis nulla regularitas censeatur nullumque in illorum respectiue Abbatem recipi possit Apostolica auctoritate 
praedicta etiam perpetuo supprimas, et extinguas eaque si suppressa et extincta cum omnibus, et singulis illorum, et quoad secundo dictum Monasterium illiusque Mensae Abbatialis, quae a Mensa Conuentuali eiusdem sedodicti Monasterij separata ut praedicitur existit dumtaxat respectiue fructibus, redditibus prouentibus, honoribus, praerogativis praeeminentijs, Terris, Dominijs, pertinentijs Juribus, obuentionibus, emolumentis uniuersis ad praedicta Monasteria ut praedictiur suppressa, et extincta quoad secondo dictum Monasterium ad illius Mensa Abbatiale praedicta dumtaxat quomodlibet respectiue dependentibus cuiuscumque Nominis, Nature, Speciei, quantitatis, et qualitatis existant nihilo excepto, et instituto pro illius Dote et Congrua Puerorum in et ut praedicitur alendorum, ed edocendorum, nec noe Preceptorum in eo edocentium, ac Offitialium aliorumque Ministrorum inibi inseruientium praedictoum sustentatione; ita quod liceat eidem Collegio seu Seminario ut praedicitur erecto et instituto, iliusque pro tempore existentibus Administratoribus, seu Deputatis Monasteriorum praedictorum ut praedicitur suppressorum, et extinctorum, et quoad secundo dictum Monasterium illius Mensae Abbatialis dumtaxat fructuum, redituum, prouentuum, honorum, praerogatiuarum, praeeminentiarum, Jurisdictionum, iurium, obuentionum, pertinentiarum et emolumentorum, aliorumque praemissorum ueram, reale, corporale et actualem possessionem per se uel alium seu alios eorum, ac dicti Colegij, seu Seminarij ut praedicitur erecti, et instituti Nomine propria auctoritate libere apprehendere, et apprehensam perpetuo retinere, illaque locare dislocare, erhendare, exigere, percipere, leuare, recuperare, ac in Collegij seu Seminarij ut praedicitur erecti, et instituti huiusmodi usus utilitate neccessitateque, ac puerorum in eo pro tempore alendorum, e edocendorum, nec non praeceptorum ac Offitialium aliorumque Ministrorum inibi inseruientium praedictorum sustentationem conuertere Dioecesani Loci, uel cuiusuis alterium superioris licentia desuper minime requisita supportatis tamen prius per Collegium seu Seminarium ut praedicitur erectum, et institutum huiusmodi, illiusque administratores seu deputatos pro tempore existentes praedictos omnibus, et singulis dictorum Monasteriorum ut praedicitur suppressorum, et extinctorum Oneribus. Mensa tamen Conuentualis secundo dicti Monasterij, illiusque Prioris Claustralis ac Monacorum, et Conuentus Juribus etiam quoad Monacorum Numerus, et fructus, redditus, et prouentus ad eamde Mensam Conuentuale spectantem saluis firmis, et illaesis ut prius remanentibus eadem Apostolica auctoritate similiter perpetuo unias, anectas, et incorpores. Nos enim Collegio seu Seminario ut praedicitur erecto, et instituto huiusmodi nec non pueris, Magistris, praeceptoribus, Offitialibus, alijsque Ministris in eo pro tempore existentibus, ut omnibus, et quibuscumque priuilegij exemptionibus, libertatibus, facultatibus, et indultis, quibus caetera puerorum Ecclesiastica Collegia seu Seminaria, ac huiusmodi Magistri, Offitiales, alijque Ministri in eis existentis quouismodo utuntur, potiuntur, et gaudent, ac uti, potiri, et gaudere poterunt quomodolibet in futurum non solum ad eorum instar, sed aeque principaliter uti, potiri, et gaudere ualeant in omnibus, et per omnia Apostolica auctoritate concedimus, et indulgemus, illaque eis comunicamus, dictumque 
Collegium seu Seminarium ut praedicitur erectum, et institutum sub Beati Petri Apostoli, et Sedis Apostolicae, atque N(ost)ra protectione suscipimus, nobisque imediate subjcimus, ac a quacumque alia Superioritate liberum, imune, et exemptum declaremus, nec non dicto Vincentio Archie)pisco)po, ac pro tempore existenti Archie(pisco)po Jadrensis praedicto plenam, ac liberam facultatem, et auctoritatem pro salubri directione, et conseruatione Collegij seu Seminarij ut praedicitur erecti, et instituti huiusmodi illiusque bonorum, rerum, ac Jurium tam temporalium, quam Spiritualium Economos, Rectores, aliosque Ministros, et Offitiales in eo deputandi, amouendique et alios eorum loco sufficiendi; Ordinationes praeterea, et Statutas aequa tamen, et honesta, Sacrisque Canonibus, et Constitutionibus Apostolicis, ac eiusdem Concilijs Decretis praedictis non repugnantias faciendi, et edendi, quae tamen semel sic facta, et edita a Sede Apostolica approbari, et confirmari debeant, ac si approbata, et confirmata imutari nullo unquam tempore, aut alia de nouo addi ualeant Apostolica auctoritate praedicata etiam concedimus, et impartimur, illaque ab Omnibus pueris, Magistris, et Offitialibus alijsque Ministris in Collegio seu Seminario ut praedicitur erecto, et instituto huiusmodi existentibus eique Ministrantibus inuiolabiliter obseruari ordinantes, quoque nullo unquam tempore de subreptionis, uel obreptionis, aut nullitatis uitio, seu intentionis $\mathrm{N}$ (ost)rae, uel quopiam alio deffectu uotari, impugnari, inualidari, retractari in ius, uel contouersiam uocari ad uiam, et terminos iuris reduci, aut aduersus eas quocumque iuris, uel facti aut gratiae remedium impetrari, aut etiam motu proprio, deque Apostolicae potestatis plenitudine concedi, nec sub quibusuis limitationibus, derogationibus, aut alijs contrarijs dispositionibus per quotcumque Romanos Pontifices successores N(ost)ros, ac etiam per Nos et Sedem Apostolicam praedictam pro tempore faciendis, et concedendis comprehendi posse, uel debere sed semper ab illijs excipi et quoties illae emanabunt, toties in pristinum, et eumdem, in quo ante praemissa quomodolibet erant... Restitutas, repositas, et plenarie integrates, ac de nouo etiam sub quacumque posteriori Data per dictum Vincentium Archie(pisco) pum et pro tempore existenti Archie(pisco)pum Jadrensis praedictum quandocumque eligenda con cessas, ualidasque, et efficaces fore, et esse suosque plenatios, et integros effectus sortiri et obtinere, ilisque ac Collegio seu Seminario ur praedicitur erecto et instituto huiusmodi, illiusque pueris, Magistris, Offitialibus, alijsque Ministris in eo pro tempore existentibus praedictis perpetuo suffragari, sicque et non alias per quoscumque Judices Ordinarios, et Delegatos etiam Causarum Palatij Apostolici Auditores, ac Sanctae Romanae Eccl(esi)ae Cardinales, etiam de Latere Legatos, Vicelegatos dictae Sedis Nuntiojudicari, et deffiniri debesre, irritumque, et imane decernimus, ac secuis super his a quoquam quauis auctoritate scienter, uel ignorante contigerit attentari Non obstantibus Constitutionibus, et Ordinationibus Apostolicis, ac dictae Ciuitatis Jadrensis, nec non Monasteriorum praedictorum, et Ordinis, cuius illa respectiue existunt etiam Juram(ent)o Confirmatione Apostolica, uel quauis firmitate alia roboratis, statutis e consuetudinibus, priuilegijs quoque indultis, et Litteris Apostolicis quibusuis Superioribus, et personis sub quibuscumque tenoribus, et 
formis ac cum quibusuis derogatoriarum derogatorijs alijsque effecacioribus effecacissimis ac inosolitis Clausulis, ac etiam irritantibus et alijs decretis in genere, uel in specie, etiam motu simili, ac alias in contrarium praemissorum quomodolibet concessis, quibus omnibus, et singulis, et si de illis, eorumque totis tenoribus, specialis, specifica, expressa, et indiuidua, ad de Verba ad Verbum, non autem per Clausulas Res, idest importantes mentio aut aliqua alia exquisita forma ad hoc seruanda foret illorum tenores praesentibus proplene et sufficienter expressis habentes, illis alias in suo robore permansuris latissime et plenissime, ac specialiter, et expresse hac uice dumtaxat derogamus caeterisque contrarijs quibuscumque. Per praesentes autem non intendimus Benefitia Ecclesiastica in primo, et secundo dictj Monasterij quomodolibet resepctiue dependentia ullatenus unire Collegio, seu Seminario per se per praesentes erecto, et instituto

Datum Romae apud Sanctum Petrum Anno Incarnationis Dominicae M.D.CCXXIX Tertio Kalendas Januarij. Pontificatus Nostri Anno Sexto 
SLIKA 1. Prva stranica prijepisa bule pape Benedikta XIII. od 30. prosinca 1729. godine o ustanovljenju glagoljaškog sjemeništa i pripojenju nadarbina Sv. Krševana u Zadru i Sv. Petra u Osoru

\section{B5 \\ Bolle d'Inftitution; è Dotacion del Seminario:}

A 33 .

1729. 30. Decembre.

DEndictus Epifcopus Seruus Seruorum Dei Vea.

13 Fratri Epifcopo Nouenfi falutem, \& Apoftoli. cam Benedictionem. Inter Sacrofancta Tridentinæ Sinodi cęlicus emiffas Sanctiones illa nobis potifimum eft Cordi per quam app. fingulas Metropolitanas, \& Cachedrales Ecclefias Ecclefiaftica puerorum Seminaria, veluti Militantis Ecclefix Tentoria erigi demandantur. \&\&c.

Cum itaque ficut Ven. Frater Vincentius Smaierich Archiepifeopus Iadrenf: nobis nuper expofuic Prouincia olim Reguum Dalmatiz, qux \& if - retroadtis temporibus florentifimus Sacrolanctre Matris Ecclefix Ager, ex quo proceres frugifereque toe prodierane Apoftolicorum dogmatum plantæ, vt ex carum erudita Irractum vbertace ipfa Mater Ecclefia innumerum filiorum fibi ftrenue militanci in Terris, \& crium: phantis in Cęlis alere confueueras cetum, nune vero Prouincia huiutmodi magna ex partefub infidelium Tyranide exiftens in tenebrofum . nullumque admitteas facrarum feicotiarum cultum impietatis Nemus, \& Schimaticis 0 . rientalibus, Hæreticilq. Septenerionalibus pré: fertim Serbianis, ac Turcis ipfis vadique referta in horridam venenatarum, ac fedarum Beluarum huiufmodi fedem conuerfa reperiatur, proptereaque eiufdem Prouincia Clerus Illiricus ignorantia tenebris obuolucus \&c. Ac

Izvor: HR-DAZD-336, Benediktinski samostan sv. Krševana, kut. 5, svež. 1.5.10., fol. 35-40 
Prilog 2. Opis obnove krovišta crkve sv. Krševana u Zadru 1792. godine. (Izvor: HR-AZDN, fond 6, Nadbiskupsko sjemenište Zmajević/ Nadbiskupska gimnazija u Zadru, Spisi, Računi i dnevnici blagajne, 18. i 19. st., Liber II.)

Registro della rinnovazione delli tetti, ed altre Opere eseguite nella Chiesa Abb(aziale) di $S($ a)n Grisogono di questa Città, a peso di questo Seminario Illirico; eccetuata qualche picciola contribuzione somministrata dalli $P(a d)$ ri Monaci di quel Monastero, come in progresso sarà specificato.

Ritovandosi li tetti Superiore e due Laterali di essa Chiesa di S(a)n Grisogono in molto disordine, e minacianti rovine per la mal loro intesa ed eseguita costruzione, e specialmente per essere assai colminati, ne è derivato che li Coppi nel loro centro assicurati con Chiodi in tutta quasi l'estenzione, questi arruginiti li spessavano, e l'Acque dilatandosi per il Legname l'avevano pregiudicato; talchè le Caene e Biscantieri nelle loro estremità infraciditi, le Banchette e tavole de medesimi quasi tutte consunte, la gravità degli indicati Colmi riposava semplicemente sopra li Muri, spogli questi anco delle Chiavi di ferro, necessarie al reciproco sostegno. Tutto ciò rissultò dalla perizia eseguita li 20 Maggio 1791 dal Proto Antonio Bernardini, qual in essa insieme manifesta non poter assicurare per alcun periodo in particolare il Colmo Maggiore, ad oggetto dell'esposto. Ogni cura hò indicata e rassegnata io Can(oni)co Giuseppe Calvi Rettore di q(ues)to Seminario alli savj riflessi del nostro Mon(signo)r Ill(ustrissi)mo e R(everendissi)mo Arcivescovo Giovanni Carsana; qual impulsato non solo dall'evidente indicato pericolo, mà ancora dalle umilissime personali suppliche a Lui rassegnate dalli $\mathrm{R}$ (everendissi)mi Monaci di essa Chiesa $\mathrm{P}(\mathrm{a})$ dre Prior $\mathrm{D}(\mathrm{o}) \mathrm{n}$ Angelo Vecchia, e $\mathrm{P}(\mathrm{a})$ dre Cellerario $\mathrm{D}(\mathrm{o}) \mathrm{n}$ Alessandro Balbi, si determinò all' impresa, d'esser effettuata con il Denaro, che Egli tiene in Deposito di ragione dell'indicato Seminario. Impegnato adunque fù per l'esecuzione il mentovato Proto Antonio Bernardini Veneziano, Uomo di esperienza, marcata nella rinnovazione delli tetti di questa nostra Chiesa Metropolitana nell'anno 1781 con comune approvazione. Ricevuti da me gli assensi e comandi del Prelato indicato, hò formato privata Scrittura con esso Proto Bernardini segnata li 11 Giugno 1791, con la quale si spiega ed impegna per la rinnovazione del solo tetto Superiore con la costruzione di sei capaci finestre, trè in ogni lato della Nave Maggiore, per rendere luminosa la Chiesa; sino ad ora con alcuni soli piccioli fenestrini, semplicem(en)te nel lato da Garbin, che la teneva ottenebrata. Considerati dal Proto li Biscantieri del riferito tetto, che esistevano $\mathrm{n}$ (umer)o 106, li computò tutti capaci con la recizione della loro estremità, $\mathrm{e}$ con una nuova quadratura per levare il patito; così le Caene parimenti con la recizione nell'estremità ove occorresse, per essere rimesse nella loro mancanza con un incalmo di Larice adequato, assicurate insieme clandestinam(en)te con Chiavi di ferro; incatramati gli incalmi, e le estremità delle medesime, nonchè quelle delli Biscantieri, e li profili tutti delle Banchette, ed incassate con tavola di Larice incatramata le teste delle Caene riferite; impegnatosi pure d'assicurare li Coppi tutti con Malte, giudicato avendo che di questi pocca quantità ne mancarebbe. Hò convenuto adunque con l'indicato Proto Antonio Bernardini l'Opera dietro espressa raporto a quanto spetta alla sua sopraintendenza, ed essecuzione; per le fatture tutte delli Marangoni, Murari, e Manuali, si nel disfacimento, 
che nella rinnovazione dell'indicato tetto Superiore; per le sei finestre con le loro Vetrate, per Tallari in argento Veneti quattrocento, e ottanta n(umer)o 480, ciascun Tallaro a Lire ventiquattro L 24, formano Moneta di Dalmazia Lire undeci milla cinquecento, e venti; dico L 11520: restando ad aggravio del Seminario la provista di tutti li Materiali occorenti, e loro trasporti, nonchè le fatture tutte appartenenti al favro, e tagliapietra.

Incoata la convenuta Opera li p(ri)mo Luglio 1791 con il disfacimento dell'accennato tetto Superiore, in progresso dell'esecuzione scoprendo con evidenza che anco li tetti laterali non potevano regere, non solo per la loro costruzione, mà ancora per li difetti rilevati nel Legname; ed insieme perchè diminuindo delli medesimi al fianco della Navata media l'elevazione, si darebbe maggior spazio per ingradire le sei determinate, e convenute finestre; consigliato con miei ossequiosi caratteri Mon(signo)r Ill(ustrisssi)mo e R(everendissi)mo Arcivescovo, che si ritrovava a Venezia per suoi affari, con rispettabili suoi rescritti 25 Luglio sud(det)to hà rimesso in me l'affare. Adunque con nuova Scrittura privata, segnata 23 Agosto 1791 a tal solo oggetto estesa mi sono convenuto con il Proto Bernardini dichiarito per Tallari quaranta quattro n(umer)o 44, che formano Lire mille cinquanta sei, L 1056, considerati dal medesimo Proto li Biscantieri di essi due tetti latterali quasi tutti capaci per la nuova costruzione, con la recizione delle loro estremità dovendogli però contribuire tutto d'altro Materiale occorrente, e supplire le fatture del favro e tagliapietra se occorressero.

Compite quasi le determinate convenute Opere, il R(everendissi)mo P(a)dre D(o)n Angelo Vecchia Prior dell'indicato Monastero considerata la Cappella Maggiore, ove formano Coro, nonnostante le sei finestre da nuovo eseguite nella Navata media che non avrebbe sufficiente lume, per esser la medesima travagliata con figure Mosaiche antiche e di molto deterorate, rapresentanti nella Voluta il Redentore, ed a fianchi di esso la B(eata) Vergine, e $\mathrm{S}(\mathrm{a}) \mathrm{n}$ Giovanni $\mathrm{B}(\mathrm{a}) \mathrm{tt}(\mathrm{ist}) \mathrm{a}$, ed in giro li dodeci Appostoli; hà esibito il riferito $\mathrm{P}(\mathrm{a})$ dre Prior di ragione del Monastero per la demolizione dell'indicate figure, dell'otturazione di quattro piccioli fenestrini, ed un alquanto maggiore; per la formazione d'un capace fenestrone in mezzo ad essa Cappella, per il primo e secondo incarto ed imbianco, Tallari venti quattro $\mathrm{n}^{\circ} 24$ che formano Lire cinquecento e setanta sei, L 576, dovendo il di più cadere a peso del Seminario. Ciò maturato da Mon(signo)r Arcivescovo, ed a me dal medesimo appoggiato, accordai la semplice fattura con il Proto Bernardini per Tallari trenta $\mathrm{n}^{\circ} 30$, che formano L 720 di questa Moneta, come dalla sua Scrittura 2 Novembre 1791, e questa pure in relazione delle precedenti non computate le fatture di tagliapietra e favro. Esso $\mathrm{P}(\mathrm{a})$ dre Prior Vecchia mi consegno pontualm(en)te gli già esibiti ventiquattro Tallari $\mathrm{n}^{\circ} 24$, con condizione che di essi soldi non ne dovessi fare alcune memoria; non volendo comparire d'aver somministrato in vantaggio dell'impressa fabbrica alcun succidio, contemplando l'indicato dovesse esser il tutto considerato a peso del Seminario. Mà ciò verificar non si poteva, prima perchè l'indicata Opera della Cappella non era eseguibile da alcun Artefice per li sei Tallari aggionti dal Seminario alli ventiquattro contribuiti dal riferito $\mathrm{P}(\mathrm{a})$ dre Prior (qual ne diede altri trè per altra Opera, che sarà in seguito segnata); e poi perchè il Monastero ne tempi in dietro, da chè il Seminario è in possesso dell'Abbazia fù Zeta, ex se, senza alcun suffragio del Seminario hà eseguito molte Opere a benefizio della antidetta Chiesa di S(a)n Grisogono, trà quali la rifuzione della 
Campana Maggiore; l'erezione dell'Altare di Marmo con la Immagine di S(an) Grisogono e $S(a) n$ Zoilo al fianco sinistro dell'Altare Maggiore; l'Organo antico ed in somma decadenza, che era nel fianco da Bora della Navata Magg(io)re questo demolito, aquistò l'Organo di S(a)n Simeone di questa Città, allorchè il Professor Nachich in essa Chiesa ne impiantò dell'Orchestra e Cassone moderno, come esiste sopra la Porta Magg(io)re; governò più volte li tetti della Chiesa indicata; hà sempre provedute le Sacre Supeletili; ed altro hà eseguito come dagli Documenti nel loro Archivio. Indico esser concorso sponte il Proto Bernardini, ed a proprie spese raporto la fattura, in relazione del convenuto, di otturare con Muro pieno in Calcina li dieci fenestroni bislonghi con voluta, esistenti nella Navata media cinque per fianco a semplice lume delli Coridori sotto li Soffitti inferiori.

Rimanendo in qualche disordine li Muri delle due Navate laterali, ed in quella da Garbin nella Cappella dell'Altar di S(a)n Grisogono ritrovandosi quattro finestre irregolari, ed ora superflue, così nella facciata in Maistro nel lato destro due altre consimili, e ciascuna con Vetri fondi, occorrenti per le finestre determinate; hò convenuto con il Proto per otturare di Muro essi sei fori, rimediare a qualunque disordine nelli detti Muri laterali, rimettere gli incarti, ed imbianchire ambi li spazi di essi Muri, per Lire duecento, dico L 200, a qual effetto il nominato $\mathrm{P}(\mathrm{a})$ dre Prior Vecchia hà contribuito tre Tallari, che sono L 72; sicche essa fattura restò a peso del Seminario per L 128 oltre li Materiali abbisognati.

Compita la riferita fabbrica li 3 Febbraro 1792, restavano d'eseguirsi per l'intiero dal Proto in relazione delle indicate sue Scritture le sei finestre di Vetri per la Navata media, e quella nel Coro dietro all'Altar Magg(io)re; e nella facciata sopra la Porta la grande e sopra essa due picciole, che riferiscono al Soffitto, e queste trè non convenute raporto alla fattura; delle quali tutte fù negletta l'esecuzione dal nominato Proto sino Giugno prossimo venturo; e li 16 dell'indicato Mese furono compite dal medesimo ed alli suoi luoghi annicchiate. In virtù di chè gl'antidetti R(everen)di Monaci l'Altare a fianco da Garbin, prima con l'Immagine di S(a)n Antonio Abbate, questa tutta deteriorata e non più esponibile, sostituirono in esso un Crocefisso con Croce antica, dal d(et)to Proto restaurata, e stabilita con Sfazone, che in quadro la contorna, serviva prima di Baldacchino sopra l'Altar Magg(io)re, il Proto indicato dalli riferiti Monaci con il peculio del Monastero fù supplito; eseguite insieme altre opere dagli nominati raporto all'adornamento della Chiesa. Lo chè compito principiarono Offiziare essa Chiesa con Messa cantata solene li 24 Giugno antidetto, giorno di S(a)n Gio(vanni) B(a)tt(ist)a caduto in Domenica.

\section{A di 25 Giugno 1792}

Rassegnata la presente amministrazione descritta partitam(en)te in un Libro particolare da me Can(oni)co Giuseppe Calvi Rettore del Seminario Illirico a Mon(signo)r Ill(ustrissi)mo e R(everendissi)mo Arcivescovo Giovanni Carsana raporto alle fatture eseguite con suo ordine nella Chiesa di S(a)n Grisogono di questa Città, e dal medesimo Mon(signo)r sommenistratemi le controscritte Lire venticinque mille, trecento e due, Soldi undeci del corpo del Denaro, che esso tiene in deposito di ragione dell'indicato Seminario, in questo giorno anco hò cantelato il riferito Prelato per l'indicato Denaro di proprio mio pugno in un foglio; e siccome all'incontro mi sono dato Credito degli indiviuati Soldi, così a pareggio qui mi dò Debito delle riferite L 25302:11. 
SLIKA 2. Obnova krovišta crkve sv. Krševana u Zadru 1792.

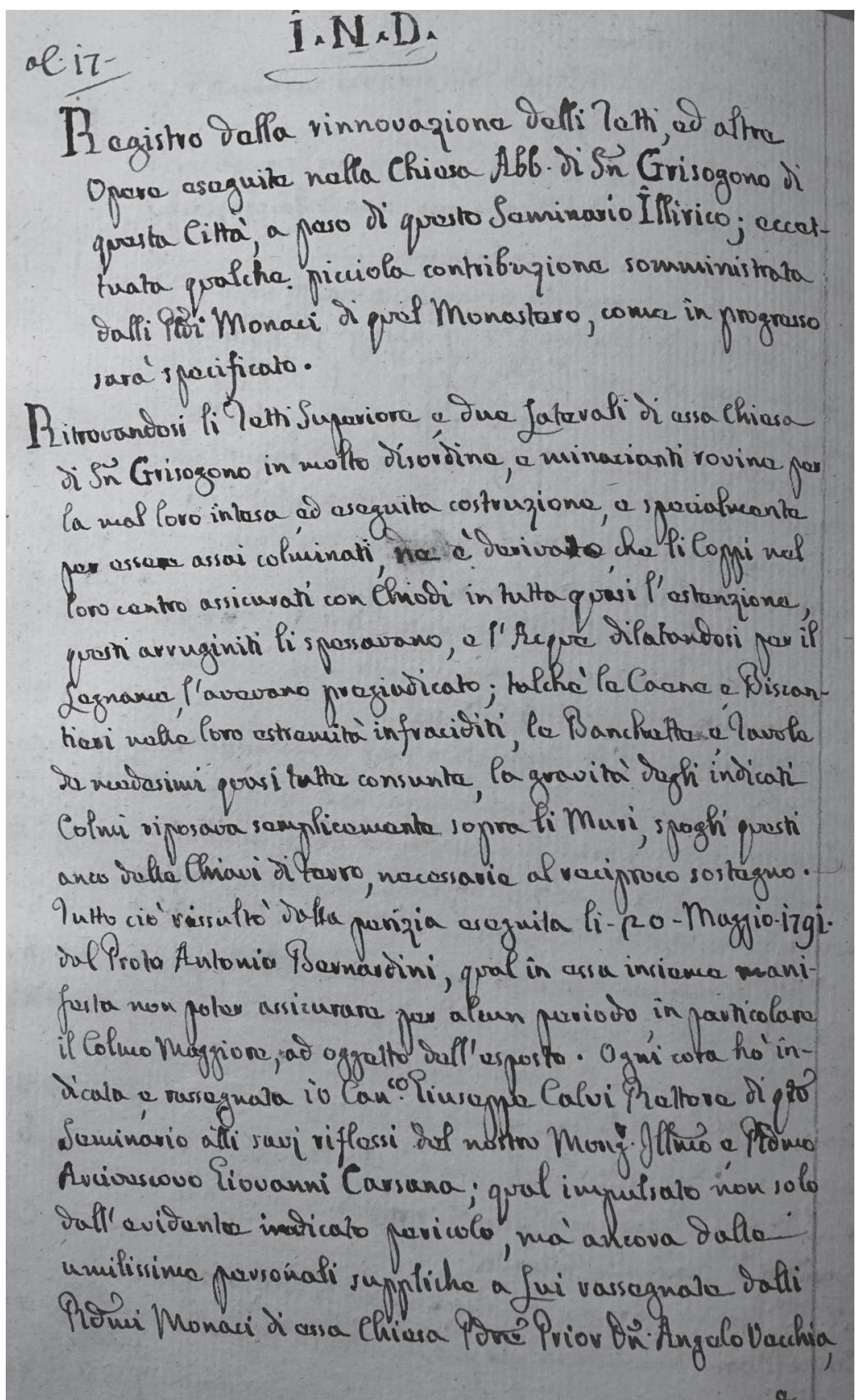

Izvor: HR-AZDN, fond 6, Nadbiskupsko sjemenište Zmajević/Nadbiskupska gimnazija u Zadru, Spisi, Računi i dnevnici blagajne, 18. i 19. st., Liber II. 
Prilog 3. Postavljanje novog tijeska za ulje u sjemenišni mlin u Brbinju 1794. (list 37) (Izvor: HR-AZDN, fond 6, Nadbiskupsko sjemenište Zmajevićl Nadbiskupska gimnazija u Zadru, Spisi, Računi i dnevnici blagajne, 18. i 19. st., Liber II.)

Dichiarazione dell'impianto del nuovo torcolo da Oglio in Birbigno in questo anno 1794.

Da chè mi ritrovo alle regenza di questo Seminario non esistendo Torcolo da Oglio nella Villa di Birbigno, ove pur vi esiste il Molino di ragione d'esso Pio Luogo; trascurato esso Torcolo dalli Precessori o per mancanza di molti Olivari peridi dal fredo nel 1782, o perchè servindosi di picciolissima Macchina ad uso comune negli Scogli, continuar intendessero con quella, a fronte di molto tempo mal impiegato, e d'un dispendio considerabile, e danoso nel riddure le Paste in tante Tine alla riva del Mare, per essere sciolte da essa acqua marina, e riccuperato da quelle l'Oglio a forza di Papiglie (così indicate in idioma Illirico); stante il frutto ubertoso si è dimostrato e raccolto in questo Autuno dall'anno 1793 a diferenza di tutti gli anni scorsi che sempre fu meschino, e per impedire con l'aletamento dell'utile a quelli Villici non passare in altre parti per riddure le loro Olive in Oglio, come pratticavano la maggior parte con portarsi a Lossin con aggravio e rischio; mi sono determinato con gli assensi del Mon(signo)r Ill(ustrissi) mo e R(everendissi)mo Arci(vesco)vo Giovanni Carsana farne costruire uno a norma degli esistenti in questa Città uno di ragione Eredi Stocco e l'altro degli Eredi Cicanti. Ordinato da me a tal oggetto il Legname nell'anno precedente al R(everen)do Sig(no) r D(o)n Pietro Bonicelli da Lossin Grande, di questo anche fece seguire il taglio in tempo opportuno; mà le combinazioni non permisero riddurlo a questa parte nel tempo determinato. Frà tanto consigliato dall'intendente Sig(no)r Donato Ferrari d'appigliarmi ad altra Machina più espediente, utile, ed occupante picciolo spazio, in questa parti ancor non veduta ne praticata, ideata ed eseguita dal Sig(no)r Grimaldi Genuese e Marchese di Seminara in Calabria, ivi stabilita, e chè con essa Macchina o sia Torchio hà dimostrato con il fatto a quelle parti produre questo d'utile per la sua forza di spremere il ventiquattro e venticinque di più per cento d'Oglio, a diferenza delle usuali Macchine che cola usano, impiegandovi un solo Uomo per l'esecuzione; capacitato io dalla ragione ed dal vantaggio oltre la dichiarazione fattami anco dalla produzione a Stampa data da esso Sig(no)r Grimaldi, mi appighai a questo, e del Legname occorrente e diverso ne ho fatta nuova ordinazione all'indicato R(everen)do Bonicelli, che in tempo conveniente ne hà fatto eseguire il taglio nell'Isola di Veglia. La qualità di esso Legname e dimenzione e Due Colonne quadrate di Rovere o altro Legno forte, grosse Piedi $n^{\circ} 1$, Onzie n(umer)o 4 , alte Piedi n(umer)o 10. Un Bancacio di essa specie, largo Piedi $n^{\circ} 2$, grosso Piedi ${ }^{\circ} 1$, lungo Piedi n ${ }^{\circ}$ 1/2; Un pezzo di Olmo o altro Legno compatto per la Madre Vida, lungo Piedi $n^{\circ} 51 / 2$, alto Piedi $n^{\circ} 1$, Onzie $n^{\circ} 4$, largo Piedi $n^{\circ} 2$. Un Legno di Cornoler o Sorboler salvatico per la Vida lungo Piedi $n^{\circ} 41 \frac{1}{2}$, grosso in quadro Piedi $n^{\circ} 1$. Questi sono li pezzi principali ed esenziali; ed altro Legname provisto qui in Città, oltrè servirsi di qualche 
pezzo della prima ordinazione. Li pezzi della prima ordinazione, che dovei acquistare sono Due pezzi di Olmo longhi Piedi ${ }^{\circ} 8$, larghi Piedi $n^{\circ} 1$, grossi Oncie $n^{\circ} 4$. Un pezzo longo Piedi $n^{\circ} 8$, largo Oncie $n^{\circ} 22$, grosso Oncie $n^{\circ} 7$. Un pezzo longo Piedi $n^{\circ} 15$, grosso Oncie $n^{\circ} 9$ in quadro da un cava, e dall'altro Piedi $n^{\circ} 1$. Due pezzi longhi Piedi $n^{\circ} 8$, grossi per quadro Oncie $n^{\circ} 6$.

Effetuato adunque il taglio dell'indicato Legname, e speditomi dal R(everen)do Sig(no) r D(o)n Pietro Bonicelli li 8 Settembre 1793 con il Boscarolo M(istr)o Andrea Rugger; che aveva esso taglio eseguito, il Legname mentovato fù trasportato dalla Marina nel Cortile dell'Arcivescovile Palazzo, e collocato alle Volute di questo Seminario. Ivi diede mano all'opera il Proto Giuseppe Lipieri assieme con M(istr)o Tita Bava Veneziani, e Pubbliche Maestranze li 29 Ottobre, ed a picciole giornate, a motivo de Pubblici lavori lo compirono alla fine di Dicembre, con aver eseguito una Vida di risserva, come a mio credito stà segnato.

Li 17 Gennaro 1794 Già traslatato quasi intieram(en)te il Legna lavorato in Birbigno, in oggi mi sono portato colà assieme con il R(everen)do Economo $\operatorname{Sig}($ no)r D(o)n Giovanni Stercagl, M(istr)o Tita Bava che doveva impiantare il Torcolo, ed il Sig(no)r Donato Ferrari come intendente, e che aveva suggerito l'opera. Ivi si siamo trattenuti sino li 26, ed in tal spazzio fù impiantata, e stabilita la Machina con il suo occorrente. Qual Machina anco fù messa in pratica con la mazina d'undeci Quarte Zaratine d'Olive delle inferiori e patite derivate di ragion domenicale dalla Villa di Savro. Il torcolo lavorò a meraviglia comune, spremendo con forza, rendendosi sufficiente un solo Uomo alla comprezione immediata dello stesso, ed alla seguente con la Stanga del Molinello; talchè la pasta dopo la repplicata torchiata restò asciuta, e senza alcuna Oleozità, a deferenza delle Machine di diferente costruzione. Immediate si invogliarono non solo li Villici di Birbigno, mà ancora quelli delle Ville vicine e distanti per effettuare il loro particolar Oglio; talchè fù tale e tanto il concorso che dalli 26 Gennaro, sino li 29 Aprile (giorno in cui abbiamo dato mano alla mazina dell'Olive del Seminario) che alcuni furono costretti distaccarsi, ed a tal oggetto passare alli Lossini. Compito però l'Oglio del Pio Luogo reppigliariono gli indicati, e seguirono sino tutto Giugno. Prima però che hanno dato mano li riferiti alla mazina hò convenuto e stabilito in presenza del mentovato $\mathrm{R}$ (everen)do Economo del Sig(no)r Donato Ferrari, del R(everen)do Parroco Brunas, D(o)n Simon Odvitovich, ed altri con il Capitanio, Giudice, e Vecchiardi della Villa di dover contribuire al Seminario per ragion di Minella il Decimosettimo dell'Oglio, che riccavaranno; ciòè da diecisette Mizure, Sedeci siano per il Proprietario dell'Olive ed Oglio, ed una Mizura per il Seminario; e cosi fù stabilito, ed effettuarono il convenuto li Villici ed altri Aventori strani; non cadendo a peso del Pio Luogo se non il Molino, e torcolo con gli Utensili a questi inservienti. Capitò l'utile reale, ed il modo facile proveniente da tal eseguita Opera, da alcuni Proprietarj de Beni Olivati, rissolsero di effettuare nelle loro possessioni una tal Machina; e trà questi li primi ed immediati furono li Nobili Sig(no)ri Co(nti) Fanfogna nello Scoglio di Sverinaz, li Sutlovich in Eso, come usufruttarj delli Beni delli 
Sig(no)ri Co(nti) Canagetti; e ne destinarono essi Co(nti) Fanfogna altro in detta Villa di Eso nelle loro ragioni, e le R(everen)de Madri di S(ant)a Maria altro nella Villa di Bibigne. Portatomi a Birbigno unitam(en)te con il R(everen)do Economo Sig(nor) D(o) n Giovanni Stercagl li 29 Aprile per la Mazina dell'Olive, ed ivi considerando l'aggravio al qual doveva soggiacere il Pio Luogo per l'acquisto in contanti della Legna occorrente per la facitura dell'Oglio (lo chè si aspirava da quelli Villici) mi sono determinato a persuaderli alla contribuzione d'un fascio di Legna per ciascuna Casa gratis a tal oggetto. Li primo Maggio adunque, giorno festivo delli S(anti) App(osto)li Filippo, e Giacomo, dopo la Messa Parrochiale unito il Popolo al solito nel Sacrà della Chiesa, hò manifestato ad intelligenza di ciascuno, presente esso $\mathrm{R}$ (everen)do $\operatorname{Sig}($ no)r $\mathrm{D}(\mathrm{o}) \mathrm{n}$ Giovanni, che conveniva la meditata contribuzione d'un fascio di Legna per famiglia, nell'occorrenza della fattura dell'Oglio del Seminario proprietario del Bosco anco con oggetto, che la Villa tutto l'anno a consumo proprio particolare se ne serve senza alcun aggravio. Dopo qualche opposizione mal fondata, da alcuni proposta e da me e dal R(everen)do Ec(ono)mo spianata, il Capitanio Brunas, Giudici, e Vecchiardi di buon grado assentirono alla proposizione, ed hanno indotto pure ad assentirvi gli oppositori. Convennero adunque unanimi per la gratuita contribuzione d'un fascio di Legna per famiglia, con condizione però di dividere la Villa in trè Classi, o siano Contrade, denominato da medesimi Zaglav, Castel e Giaperschien, e di dover metter le Sorti, a quali di esse Contrade caderà il turno. Ciò immediate a loro costume effettuato innanzi ciascuno nel mentovato Sacrà, hà caduto il primo turno alla Contrada Zaglav; il secondo al Castel; ed il terzo a Giaperschien. Convenero poi li Villici indicati meco e stabilirono, che se il primo turno non fosse sufficiente con la patuita contribuzione per quell'anno, segua il secondo, e questo non compito, le Case, che da questo non fosse occorsa la Legna, diano principio nell'anno venturo, e segua il terzo turno; e parimenti se il primo non avesse compito nell'anno da esso incoato, le Case, che non avessero contribuito, diano principio nell'anno seguente, essendovi raccolto d'Olive; e quando il raccolto mancasse in un tal anno, sempre abbia debito alla contribuzione negli anni avvennire il turno o sia Contrada, o Case, a quali cessò la contribuzione, nell'anno del raccolto. Convenero e meco stabilirono in presenza dell'indicato R(everen)do Economo li Villici riferiti di venire con la loro Barca a levare il Soggetto destinato nel tempo, che si doverà mazinare l'Olive del Pio Luogo, e rimetterlo in Città dopo effettuato l'Oglio, con il turno, che praticano per il raccolto delle Biave, e della Vindemia, a norma delli Contadini dell'altre Ville stilano con loro Compatroni; e con il solo aggravio del Seminario delle Cibarie qui in Città alliquattro Remiganti, come si stila per esso raccolto delle Biave e Vindemia. Data mano adunque alla mazina dell'Olive del Seminario, derivate dlle Ville Birbigno, Savro e Bibigne colà trasportate, pontualmente le Case tutte del riparto della Contrada detta Zaglav, hà contribuito, e ciascuna asportato al Molino lo stabilito e convenuto fascio di Legna, che fù sufficiente in questo anno per tal opera; dovendo principare e seguire nel nuovo Raccolto d'Olive, quando accaderà la Contrada detta Castel. 
SLIKA 3. Postavljanje novog tijeska za ulje u sjemenišni mlin u Brbinju 1794. (list 37)

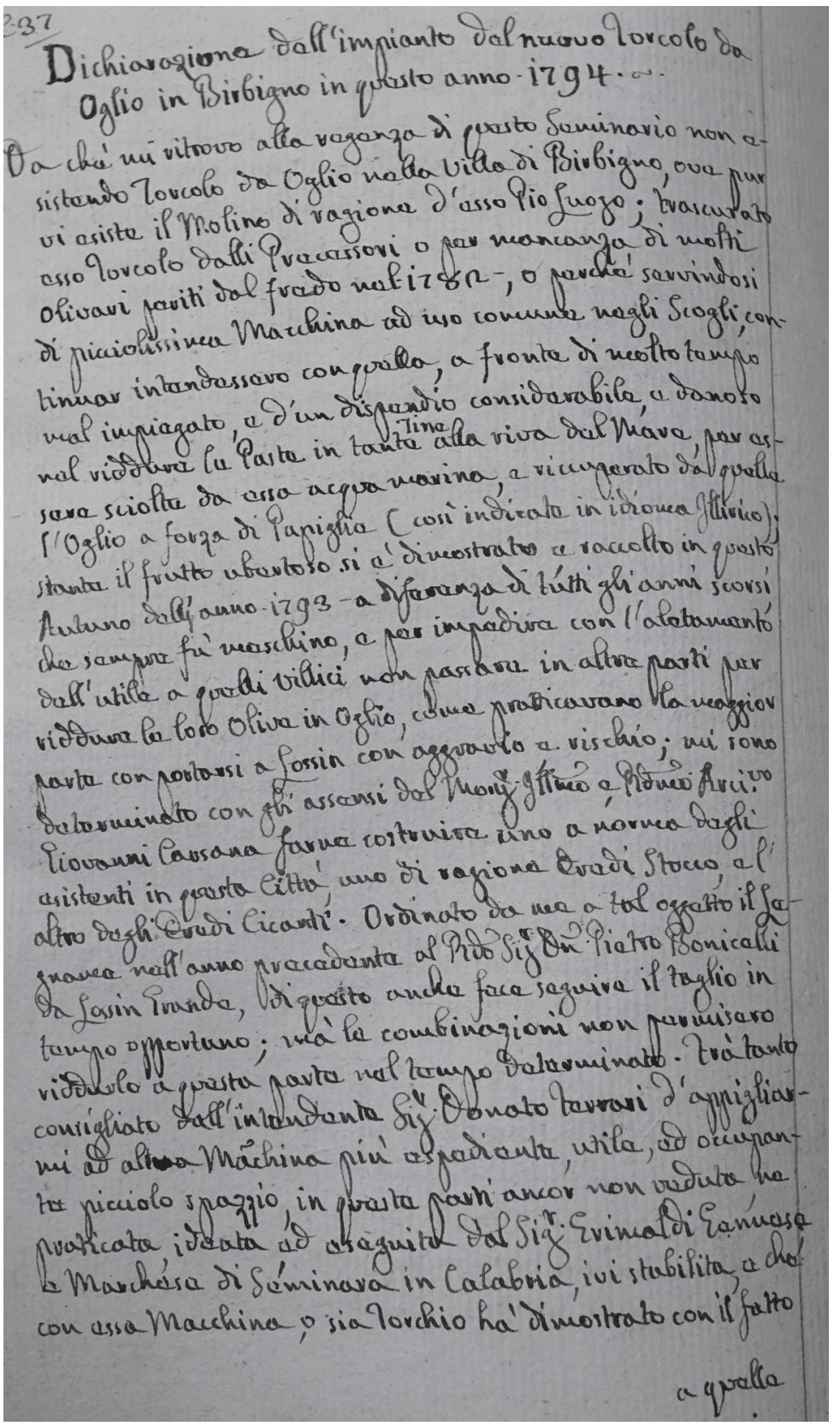

Izvor: HR-AZDN, fond 6, Nadbiskupsko sjemenište Zmajević/Nadbiskupska gimnazija u Zadru, Spisi, Računi i dnevnici blagajne, 18. i 19. st., Liber II. 


\section{Zdenko DUNDOVIĆ}

\section{ECONOMIC AFFAIRS AT ZMAJEVIĆ'S GLAGOLITIC SEMINARY IN ZADAR DURING THE RECTORATE OF CANON JOSIP CALVI (1782-1810)}

\section{SUMMARY}

On the basis of the account books of the Glagolitic seminary in Zadar from the end of the $18^{\text {th }}$ century and the beginning of the $19^{\text {th }}$ century, the paper follows economic affairs of this church institution from Zadar. The analyzed data uncover a dynamic economic life of the Glagolitic seminary, considering its estates stretching alongside the Zadar archipelago and coastline. They further help us reveal complex colonate contracts; takings and allocation of proceeds; and everyday life of the teachers and students of the seminary. The financial books of the Glagolitic seminary in Zadar present an exceptionally valuable historical source for studying the price trends of groceries and building material, and the costs related to food and beverages production in Zadar and its surroundings at the end of the $18^{\text {th }}$ century and the beginning of the $19^{\text {th }}$ century. Furthermore, the material under study offers an insight not only into the socio-political background that had an impact on production processes, but also into financial difficulties suffered by church institutions in Zadar, considering the fact that the account books of the Glagolitic seminary analyzed in this paper had been subject to frequent changes of power in Dalmatia during the $18^{\text {th }}$ and the $19^{\text {th }}$ centuries, each of the authorities having chosen a different type of policy toward church organization and the economic management of church estates. Finally, these documents clearly prove the humanitarian nature of church institutions in Zadar at the end of the $18^{\text {th }}$ century and the beginning of the $19^{\text {th }}$ century, since there were many poor families, and poverty was overpresent in general in Dalmatia in the period under study. The Glagolitic seminary in Zadar definitely counts among these institutions.

Keywords: Glagolitic seminary in Zadar; canon Josip Calvi; $18^{\text {th }}$ and $19^{\text {th }} \mathrm{ct}$.; economy. 